UNIVERSITY OF CALIFORNIA

COLLEGE OF AGRICULTURE

AGRICULTURAL EXPERIMENT STATION

BERKELEY, CALIFORNIA

\title{
THE SAN JOAQUIN EXPERIMENTAL RANGE
}

C. B. HUTCHISON and E. I. KOTOK

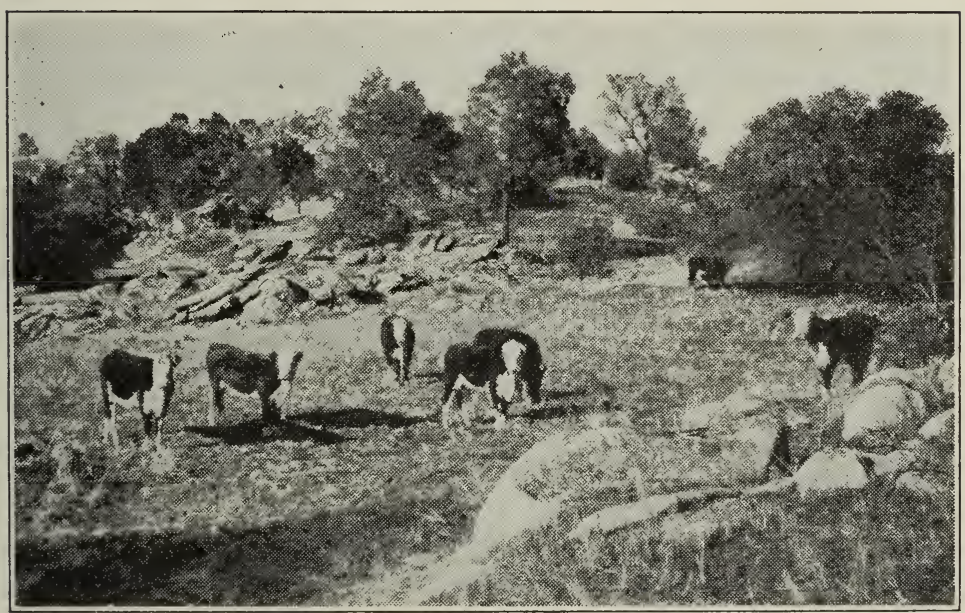

CATTLE RANGE IN THE GRANITE AREA

BULLETIN 663

April, 1942

UNIVERSITY OF CALIFORNIA

BERKELEY, CALIFORNIA 


\section{CONTENTS}

PAGE

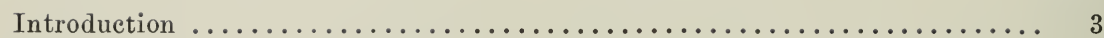

The Experimental Area, by M. W. Talbot, J. W. Nelson, and R. E. Storie.... . 7

The Forage Crop and Its Management, by M. W. TAlbot and H. H. Biswell. . . 13

Experimental Herd Management, by K. A. WAGNon, H. R. GuILbert, and G. H. НАRT. . . . . . . . . . . . . . . . . . . . . . 50

Ranch Organization and Management in the Granite Area, by E. C. Voorhies, L. A. Crawford, R. L. Adams, and G. A. Carpenter...............

Interrelations of Rodents and Other Wildlife of the Range, by E. E. HoRN and

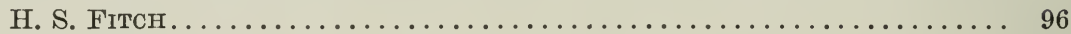

Studies on Valley Quail, by T. I. Storer, F. P. Cronemiller, E. E. Horn, and

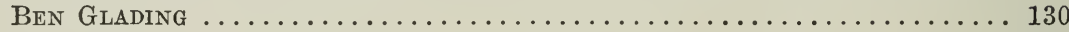

Other Studies and Experiments in the Program of the San Joaquin Experimental Range, by M. W. TALBot, H. H. BisWeld, P. B. Rowe, and A. W. SAMPSoN . . 136

Contributors and General Acknowledgments.................. 143

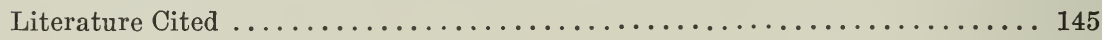




\title{
THE SAN JOAQUIN EXPERIMENTAL RANGE
}

\author{
C. B. HUTCHISON ${ }^{2}$ AND E. I. KOTOK ${ }^{3}$
}

\section{INTRODUCTION}

The тотац land area of California comprises close to 100,000,000 acres. After excluding crop lands, dense forests, brush lands, desert, inaccessible areas and parts from which grazing is excluded, there still remain upwards of $60,000,000$ acres of grazing lands.

The actual grazing value of individual acres is low but there are many of them. Collectively they are the supporting base for California's second largest agricultural industry-livestock production. This production of meat, milk, and wool is the only method of harvesting the forage wealth produced by these acres from year to year. Grass, using the term in a collective sense, is the most valuable single crop produced in the state.

Under the multiple-use concept these uncultivated lands of California have value for watershed development, timber production, livestock grazing, and recreation and wildlife. In different areas one of these uses will become paramount and the others fall in different places of relative importance.

The beef cattle population of California numbers over 1,000,000 head and there are about $3,000,000$ sheep. In addition, about 750,000 feeder and slaughter cattle and over 1,000,000 sheep are shipped into the state annually to meet consumption requirements.

Beef production is important in all areas and of major importance to the agriculture of at least two thirds of the counties. The foothills of the Sierra Nevada are of great importance for grazing and five of the ten leading counties in number of beef cattle are in this area, namely Tulare, Kern, Merced, Fresno, and Madera.

There are great variations in forage production from one part of the state to another, as influenced by soil types, rainfall, and elevation. Important as these factors are, however, climatic variability for any one given area markedly affects the quality, time of growth, and quantity of vegetative cover from season to season. The San Joaquin Experimental

\footnotetext{
${ }^{1}$ Received for publication June 3, 1941.

${ }^{2}$ Dean of the College of Agriculture and Director of the Agricultural Experiment Station.

${ }^{3}$ Director of the California Forest and Range Experiment Station, maintained by the Forest Service, United States Department of Agriculture, in Berkeley, California, in coöperation with the University of California; transferred, January 10, 1941.
} 
Range (for brevity hereinafter referred to as "the Range"), located in the granitic area near the center of the state, exemplifies range lands of rather medium value and reflects many of the unsolved problems dealing with seasonal variabilities and nutritive deficiencies.

In the Sierra Nevada foothills the vegetation is largely composed of annual forage plants. These sprout from seed in the fall following the first rains, make a varied rate of growth according to the weather conditions, and reach maturity in March or April, with shattering of their seed. They dry up in May or June and become bleached by the sun and leached by occasional summer rains. This dry material constitutes the only ground cover and gives the brown appearance of the range until the fall rains again germinate the seed and the green mantle appears.

Throughout the year these lands are grazed by varying numbers of livestock and support many species of wildlife. The nutritional value of the plant cover to animal life depends on the stage of growth and this in turn on the season of the year. In the early vegetative stages the dry matter of the green plants is uniformly high in minerals and protein with the total weight composed largely of water. The vegetation as grazed, therefore, is in the nature of a watered concentrate feed. It gradually changes from this condition as the plants mature, dry, and their seeds shatter; late in the dry season it becomes a very poor roughage-low in protein, phosphorus, and vitamin A, high in fiber, and with low palatability.

On account of the quantity and quality of this feed, part of the livestock are moved to higher mountain ranges in the national forests to the east under Forest Service grazing permits during the summer, and to valley salt grass, stubble, or irrigated pasture lands in the late summer and fall.

The problem which these lands present is how best to utilize their feed resources and still maintain the vegetative cover of desirable plant species as well as to improve its quality or quantity. From the livestock standpoint, therefore, it has been necessary to study the grazing management of animals in order to utilize best the feed on the ground by the addition of supplements to meet its nutritional deficiencies at certain seasons of the year.

With the establishment of the San Joaquin Experimental Range by the U. S. Forest Service in 1934, the University of California entered into coöperation with the Forest Service on several projects.

The University Agricultural Experiment Station placed the experimental herd of eattle on the Range, under the supervision of the Division of Animal Husbandry, to study how best to maintain on a year-round basis herds of commercial cattle on these lands. 
Studies on forage management, on the effect of the domestic animal life on the plant cover, the botany of the range, and the possibility of introducing new species of greater value have been carried out by the Forest Service. Responsibility for administration of the area, and for coördination of all studies thereon, is also vested in the Forest Service.

The impact of wild animal life on the plant cover has become recognized as an important factor and one regarding which little attention has been paid and on which data are limited. Studies of these matters have been carried out by the Division of Wildlife Research, Fish and Wildlife Service, United States Department of the Interior.

The economic aspects of the livestock industry, ranch organization and management, land values, proper-sized units and general practice in the entire granite area surrounding the experimental area will have a bearing on conclusions to be drawn after biological data on plant and animal life have been accumulated. Information toward this end has been gathered by the Giannini Foundation of Agricultural Economics of the University of California.

Game animals and birds are coming to be recognized as an asset to open patented lands through game management and controlled hunting programs. Valley quail are one of the most important upland species in this regard. Studies of these game birds on the Range lands have been made by the Division of Zoölogy of the University Agricultural Experiment Station in coöperation with the Forest Service, the Fish and Wildlife Service of the Department of the Interior, and the California Division of Fish and Game.

Several other units of the University have actively participated in the program. For example, the Department of Forestry has made extensive chemical studies of the principal forage species, the Division of Soils has covered the Range area with a detailed soil survey, and the Division of Agronomy is coöperating in the revegetation work. The Division of Agricultural Extension organized the important advisory committee and coöperates in many other ways. The coöperating agencies, with their personnel, are enumerated in more detail in acknowledgments appearing in another section of this bulletin.

It can thus be seen that on the San Joaquin Experimental Range, conceived and developed by the California Forest and Range Experiment Station, a comprehensive group consideration and attack on the problems of the range lands of California have been developed. The University has encouraged the coöperation of its specialists wherever their specialized knowledge was needed to direct and assist in accumulation of pertinent data. The data presented in the seven sections of this report by a total of eighteen authors constitute the information obtained 
by the group attack on the range problems encountered from the beginning of the studies in 1934 up to 1940. The purpose of this publication is to picture the San Joaquin Experimental Range with the kinds of going work and to report on progress and the findings to date. Such aspects of the work as have already been reported upon appear in "Literature Cited," at the end of the bulletin. 


\section{THE EXPERIMENTAL AREA}

M. W. TALboT, J. W. Nelson, aNd R. E. Storie

THE San Joaquin Experimental Range is located near the center of the state in the heart of the granite-soil section of the Sierra Nevada foothills in Madera County adjacent to the Sierra National Forest, 23 miles northeast of Madera and 28 miles north of Fresno.

The area is rolling. Elevations range between 700 and 1,700 feet; most of the area lies between 1,000 and 1,500 feet. Exposures in general are southwesterly. The drainage basin empties into a small tributary of the San Joaquin River. Numerous springs occur but no permanent streams flow through the experimental area although the many small drainage lines carry surface flows during the rainy winter months.

Experimental Facilities.-To serve the purposes of the studies and for convenience in handling livestock, the tract of approximately 4,600 acres is subdivided into numbered pastures of various sizes as indicated in figure 1 . Numbers 1 to 6 are grazing-capacity pastures devoted primarily to studies of the effect of different intensities of grazing on both range and cattle; numbers $7 \mathrm{~W}$ and $7 \mathrm{E}$ are for weaning calves, as bull pastures, and for various other handling purposes; numbers 8 to 10 are for calf pastures; and 11 to 14 are for holding the experimental herds during the periods that they are not in pastures 1 to 6 . The natural area around headquarters is not grazed; a portion serves as a check of vegetative growth under total exclusion of livestock. Saddle horses used at the station are held in the horse pasture.

For the range studies the pastures are equipped with various fenced plots to exclude rodents or livestock or both, with many permanently marked observation spots and photography stations. A forage-plant nursery is located at the headquarters; reseeding test plots are in pasture 8 ; and plots for measuring runoff and erosion are in number 7 . Rodent enclosures are located in pasture 1. A more detailed discussion of these pastures, enclosures, and plots will be found elsewhere in this report.

In all the pastures, springs and seeps have been developed and equipped with troughs to furnish water for livestock. Additional cattle facilities include two sets of corrals, holding pens, scales, dehorning chutes, and a shed for storage of supplemental feeds.

Soils.-About 87 per cent of the land on this tract consists of residual soils formed in place through the decomposition and disintegration of the underlying coarse-grained granitic bedrock. As a general rule the bedrock occurs at a depth varying from about 6 inches to $4 \frac{1}{2}$ feet from 


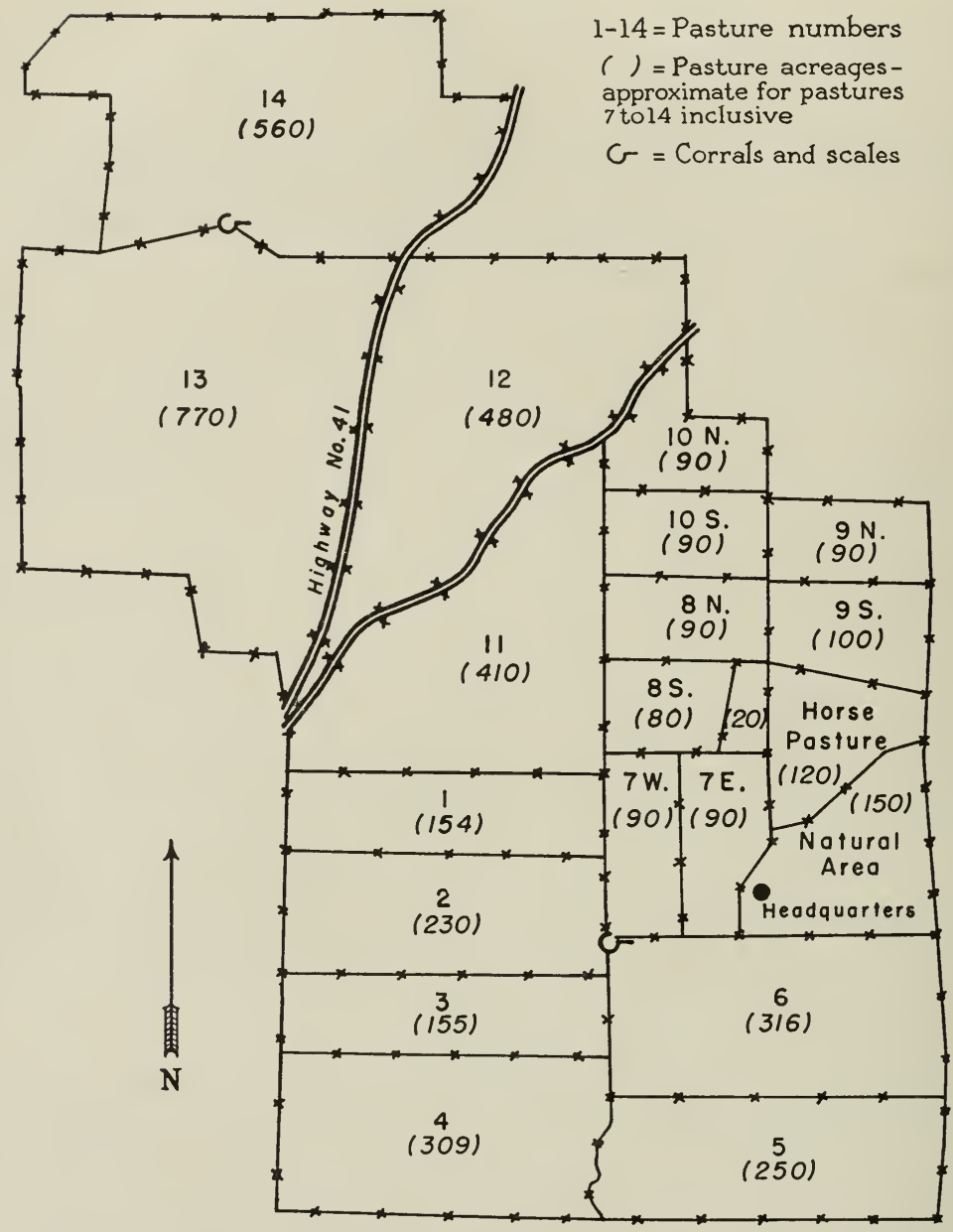

Fig. 1.-Pasture diagram of the San Joaquin Experimental Range. Some of the original pastures, designated by numbers, were later divided into north and south, or east and west, sections. For instance, $9 \mathrm{~N}$ is the north part of the original pasture 9 .

the surface. Over much of the tract the soils are less than 2 feet in depth. Characteristically they are of sandy-loam or stony-sandy-loam texture, of neutral reaction, and of brown or grayish-brown color with low organic-matter content. These soils occupy a rolling to steep surface. Nearly all the residual soils are classed with the Vista series, there being a small area of the related Fallbrook series-soils of redder color. Although these residual soils are permeable to the penetration of rain, their water-holding capacity is low owing to their coarse texture and the small volume of soil overlying the bedrock. 


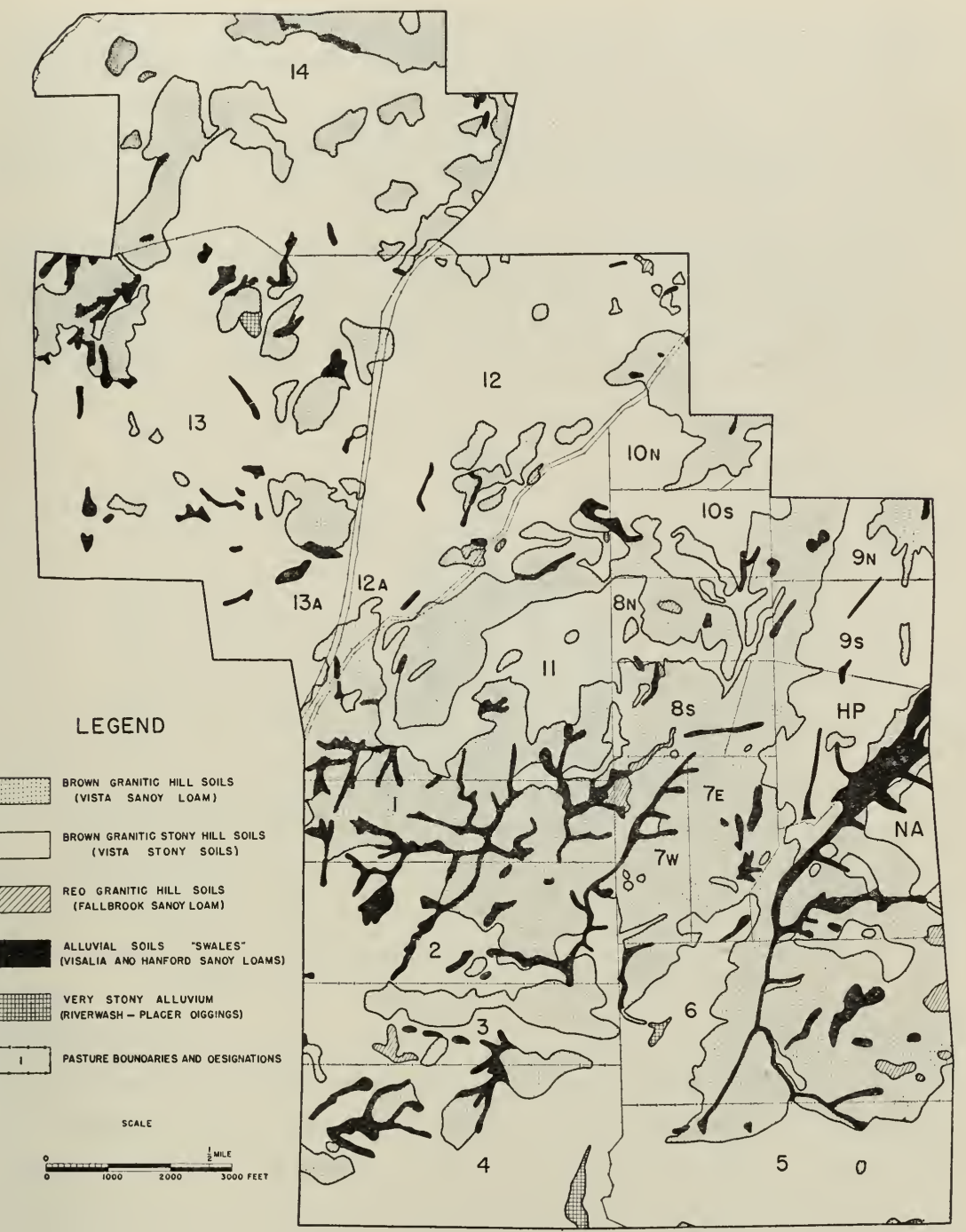

Fig. 2.-Soils of the San Joaquin Experimental Range. References to numbers and areas are given in figure 1.

About 12 per cent of the tract has darker-colored alluvial soils occurring in the swales and small valleys. These have been classed with the Visalia series, and are deep and productive. The period when forage is green and nutritious is longest on these soils; owing to their position, they retain moisture much longer than the surrounding hill soils.

Miscellaneous material classed as riverwash and placer diggings make up about 1 per cent. These are of no agricultural importance. 
The occurrence of these various soils on the Range is shown in figure 2.

Over most of the area, with the exception of the swales, by early summer the moisture content of the upper soil is reduced below the minimum amount from which plants can extract water for their needs. Below a depth of 2 feet, however, some moisture is usually available throughout the season.

Climate.-The climate is characterized in general by mild winter temperatures and high summer temperatures and by a distinct winter rainy season followed by a comparatively rainless summer period. Snow is rare. From these broad features of climate and weather arise some of the

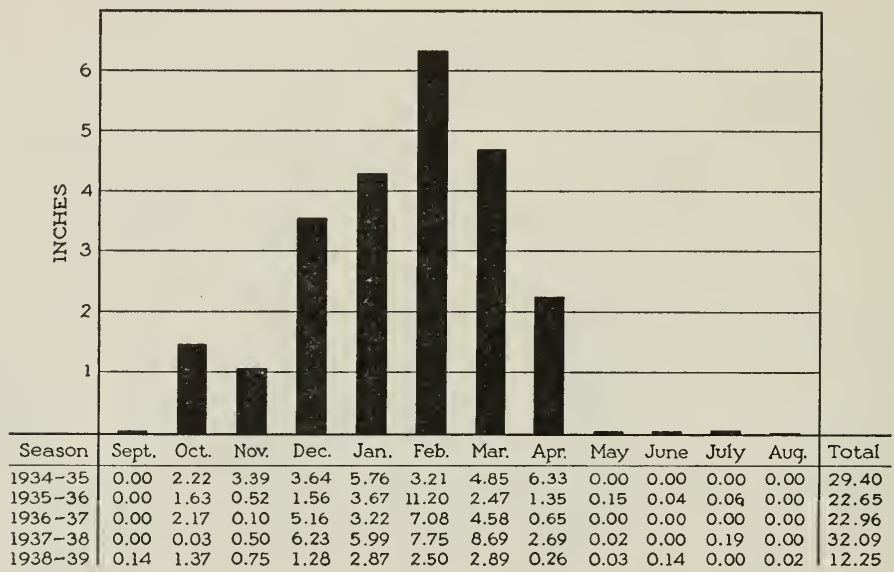

Fig. 3.-Average monthly and annual rainfall at the San Joaquin Experimental Range since the station was established.

most difficult problems of range and its management. Seasonal precipitation as treated here begins in September; and has averaged 23.83 inches (fig. 3 ) for the five-year period since the experimental tract was established in 1934. This short-period average is considerably in excess of a probable average of approximately 17 or 18 inches, as derived from U. S. Weather Bureau records from older stations in the locality for a period of twenty-five years. During the first four seasons, 1934-35 to 1937-38, precipitation averaged 55 per cent higher than the probable average for the preceding twenty years. In contrast, precipitation during the fifth season fell 30 per cent below the twenty-year average. Such fluctuations in rainfall from season to season are not unusual.

Distribution of precipitation during the five years, by seasons and by months (fig. 3 ) shows that nearly 80 per cent of the rain fell during the 4 months of December through March. Virtually none fell during the 5 summer months from May through September. Occasional storms 
bring a rainfall of 1 to 3 inches in 24 hours, but a greater intensity is seldom recorded. Most of the precipitation comes from comparatively gentle rains.

The maximum, mean, and minimum air temperatures, averaged by 5-day periods for four seasons, 1935-36 to 1938-39 inclusive, are shown in figure 4. Maximum temperatures during the dry summer season often exceed $105^{\circ} \mathrm{F}$ for several days in succession and have reached $115^{\circ}$. Minimum temperatures during this period are usually between $60^{\circ}$ and $70^{\circ}$, and very seldom remain above $75^{\circ}$. Winter temperatures are mild but frequently fall slightly below freezing. Temperatures have occasion-

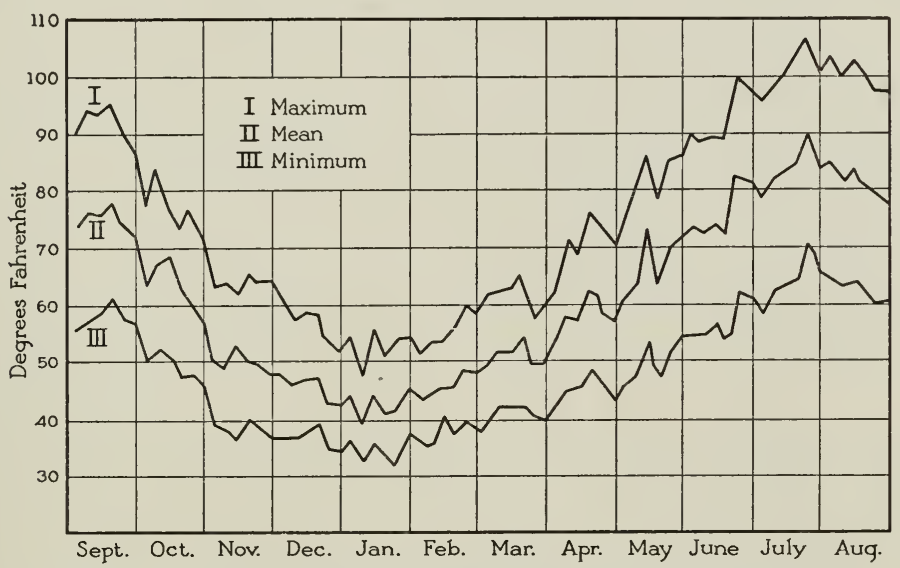

Fig. 4.-Air temperatures, averaged by five-day periods for four seasons, 1935-36 to 1938-39 inclusive.

ally averaged around $25^{\circ} \mathrm{F}$ for several days in succession. The lowest temperature recorded was $17^{\circ}$ in January, 1937 , but this was during one of the coldest periods on record for the surrounding region.

Maximum temperatures at the soil surface are high during the summer months, occasionally reaching $150^{\circ} \mathrm{F}$, with one record of $160^{\circ}$. The highest average reading for a month at three stations was $147^{\circ}$.

Relative humidity is high during the winter, but low during the summer period, with readings on some days as low as 5 to 8 per cent.

In contrast to numerous other localities with semiarid forage types, average air movement is comparatively slight and fairly constant throughout the year. Strong and continued winds seldom occur.

During the early stage of forage development in winter, cold, drying northerly winds frequently slow down growth; and in the spring the curing of the forage is often hastened by drying winds. The risk of losing forage from fire in the summer is greater during periods of increased wind movement. 
Sun intensity is high during the summer; cloudy days seldom occur during May, June, July, August, or September. Fog is frequent during the winter rainy period, when several foggy days may appear in succession.

Vegetation and Life Z Zones.-The experimental area lies in the lower portion of the woodland zone between the treeless plains below and the higher brushy and timbered belts. This section of the foothills is characteristically open and everywhere accessible to livestock. Much of the area has an orchardlike appearance, with scattered trees and bushes and occasional dense clumps of shrubs. The low ground cover, consisting chiefly of annual grasses and herbs instead of perennials that dominate most western range areas, is made up of a large number of different species. In the language of biologists, the area lies near the lower boundary of the Upper Sonoran life zone, with its characteristic plant and animal life as described in later sections of this bulletin. 


\title{
THE FORAGE CROP AND ITS MANAGEMENT
}

\author{
M. W. TALBot and H. H. BISWELl
}

MANY OF THE range-management problems of the foothill section are directly related to the character and behavior of the forage crop, a crop consisting almost entirely of annual plants and often referred to as the "annual type." This peculiar forage is made up of a large number of plant species, both native and introduced. The various kinds have different growth habits and they fluctuate widely in volume and abundance from year to year. They make some growth during the winter, reach maturity during a short active growing period in the spring, and then quickly dry. Tenacious seeding habits, nutritional deficiencies in summer, and different reactions to grazing and protection are additional properties of the forage crop of this area, in which range problems are wholly different from those on "perennial-type" ranges. A thorough understanding of these problems can be obtained only through knowledge of the character and behavior of this unique forage type around which management practices must largely be based, for perennial herbs are so sparse that they play only a negligible part in management practices in this area.

This section contains a description of the forage, a discussion of its characteristic growth and behavior, and a report on experiments dealing with the practical question of how it can be grazed to give maximum yields and at the same time be maintained and, if possible, be improved. It should be considered a progress report since the studies are in their early stages and some of the trends or conclusions may be modified by study over a longer period. This discussion, which stresses forage, is closely related to the following sections which emphasize the animal. Both are important in a clear understanding of the range problems of this region.

\section{PLANTS THAT MAKE UP THE FEED}

Although three species of plants account for more than half of the forage on the experimental area (table 1), the forage cover here and on the adjoining foothills is composed of a large number of different kinds of plants, many of which occur in small amounts and are seldom noticed. Some 225 different species (other than trees and shrubs) have been recorded on the area during the past five years and the list is still incomplete. Of these, 190 are broad-leaved plants, 30 are grasses, and 5 are grasslike plants (rushes). During the period of study the forage crop has been composed almost equally of broad-leaved herbs and grasses, except in 1935 when the broad-leaved herbs made up about three fourths 
of the cover. Of the grass species present, only a few are important range plants. The sparse grasslike plants have varied from less than 1 to almost 4 per cent. Perennial herbs have totaled less than 1 per cent during four of the five years. The herbaceous plants that have represented 1 per cent

\section{TABLE 1}

Percentages of All Grasses and Herbs That Comprised as Much as One Per Cent of the Cover at the Height of the Growing Season*

\begin{tabular}{|c|c|c|c|c|c|c|}
\hline Species & 1935 & 1936 & 1937 & 1938 & 1939 & Average \\
\hline Broad-leaf filaree................... & 34.0 & 41.7 & 33.5 & 15.5 & 28.1 & 30.6 \\
\hline Soft chess.................... & 1.4 & 19.7 & 31.7 & 17.0 & 26.7 & 19.3 \\
\hline Foxtail fescue ...................... & 13.6 & 17.2 & 9.3 & 10.1 & 12.9 & 12.6 \\
\hline 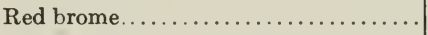 & 1.4 & 2.1 & 3.0 & 2.0 & 2.7 & 2.2 \\
\hline Tomcat and white-tip clovers. ........ & 4.2 & 0.3 & 0.5 & 5.3 & 0.7 & 2.2 \\
\hline 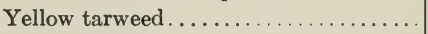 & 5.1 & 0.6 & 0.2 & 3.2 & 1.2 & 2.1 \\
\hline Maiden clover .................. & 1.8 & 0.5 & 0.4 & 5.1 & 1.8 & 1.9 \\
\hline 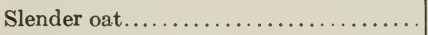 & 1.2 & 2.4 & 4.0 & 0.5 & 0.8 & 1.8 \\
\hline Spanish clover................... & 0.9 & 1.1 & 0.5 & 4.9 & 1.8 & 1.8 \\
\hline 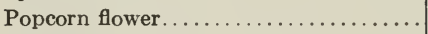 & 2.6 & 0.3 & 2.4 & 1.3 & 2.0 & 1.7 \\
\hline Toad rush $\ldots \ldots \ldots \ldots \ldots \ldots \ldots \ldots \ldots$ & 2.8 & 0.4 & 0.5 & 3.1 & 0.0 & 1.4 \\
\hline 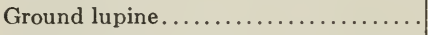 & 0.7 & 0.1 & 0.2 & 2.9 & 2.6 & 1.3 \\
\hline Ripgut grass $\ldots \ldots \ldots \ldots \ldots \ldots \ldots \ldots$ & 0.2 & 1.0 & 3.5 & 0.8 & 0.7 & 1.2 \\
\hline Birdseye gilia . . . . . . . . . . . . . . . & 3.5 & 0.1 & 0.1 & 0.5 & 0.6 & 1.0 \\
\hline 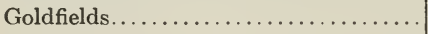 & 2.8 & 0.5 & 0.1 & 0.8 & 0.7 & 1.0 \\
\hline Red-stem filaree...$\ldots \ldots \ldots \ldots \ldots \ldots$ & 2.9 & 0.7 & 0.1 & 0.2 & 0.5 & 0.9 \\
\hline Layia............................ & 2.3 & 0.4 & 0.1 & 0.2 & 0.4 & 0.7 \\
\hline Linanthus.................... & 2.2 & 0.3 & Trace & 0.3 & 0.4 & 0.6 \\
\hline Rattlesnake weed..$\ldots \ldots \ldots \ldots \ldots$ & 0.5 & 0.3 & Trace & 1.0 & 0.5 & 0.5 \\
\hline Tree clover........................ & 0.2 & 0.1 & 0.1 & 0.5 & 1.6 & 0.5 \\
\hline 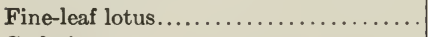 & 0.2 & 0.1 & 0.1 & 1.3 & 0.2 & 0.4 \\
\hline 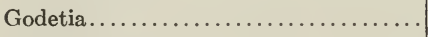 & 0.2 & 0.2 & 0.1 & 1.1 & 0.1 & 0.4 \\
\hline Poverty fescue.$\ldots \ldots \ldots \ldots \ldots \ldots \ldots$ & 1.2 & 0.6 & Trace & Trace & Trace & 0.4 \\
\hline Others and traces.................. & 14.1 & 9.3 & 9.6 & 22.4 & 13.0 & 13.5 \\
\hline
\end{tabular}

* Based on inventories covering over 1,440 acres. The least number of plots used in any inventory was 1 for each 2 acres in 1938 and 1939. The data for the 1937 crop were based on clippings, and for the other years, on estimates.

or more of the cover at the peak of growth are listed in table 1 and illustrated in figures 5 to 7 inclusive.

Introduced, or alien, species now comprise a large percentage of the cover, averaging over 60 per cent for the five years (fig. 9). Several are among our most valuable range plants and have added to the value of the forage. Others are inferior and even detrimental. The kind of plant cover existing throughout this region before the white man came can never be determined precisely since there is no early literature that adequately describes it $(1)^{4}$ and virtually no remaining samples of it.

A few of the most important plants, those on which management practices must largely be based, are discussed in more detail in this

"Italic numbers in parentheses refer to "Literature Cited" at the end of this bulletin. 
section. These plants are important for various reasons : some are abundant; others are relished by cattle; and still others reveal something of the range condition.

The common and botanical names of the various species mentioned in this bulletin are given in the following list:

\section{Grasses and Grasslike Plants}

Australian chess, Bromus arenarius Labill.

Bermuda grass, Cynodon Dactylon (L.) Pers.

Common foxtail, Hordeum murinum $\mathrm{L}$.

Common spike rush, Eleocharis palustris R. \& S.

Foxtail fescue, Festuca megalura Nutt.

Meadow barley, Hordeum nodosum L.

Melic grass, Melica californica Seribn. and $M$. imperfecta Trin.

Pine bluegrass, Poa scabrella (Thurb.) Benth.
Poverty fescue, Festuca confusa Piper

Purple needlegrass, Stipa pulchra Hitchc.

Red brome, Bromus rubens $\mathrm{L}$.

Ripgut grass, Bromus rigidus Roth.

Slender-leaf rush, Juncus oxymeris Engelm.

Slender oat, Avena barbata Brot.

Smilo, Oryzopsis miliacea (L.) Benth \& Hook.

Soft chess, Bromus mollis L.

Toad rush, Juncus bufonius $\mathrm{L}$.

Wimmera rye grass, Lolium rigidum var. strictum (Presl.) Jansen

\section{Broad-Leaved HerbS}

Alfalfa, Medicago spp.

Baby blue-eyes, Nemophila Menziesii $\mathrm{H}$. \& A.

Birdseye gilia, Gilia tricolor Benth.

Blue dicks, Brodiaea capitata Benth.

Broad-leaf filaree, Erodium Botrys Bertol.

Buckthorn weed, Amsinckia Douglasiana DC.

Bur-clover, Medicago hispida Gaertn.

California buttercup, Ranunculus californicus Benth.

California everlasting, Gnaphalium californicum DC.

California poppy, Eschscholtzia californica Cham.

Catchfly, Silene gallica L.

Common chickweed, Stellaria media (L.) Cyr.

Creeping-rooted alfalfa, Medicago sp.

Dock, Rumex spp.

Eriogonum, Eriogonum spp.

Filaree, Erodium spp.

Fine-leaf lotus, Lotus subpinnatus Lag. Garden burnet, Sanguisorba minor Scop. Godetia, Godetia spp.
Goldfields, Baeria chrysostoma F. \& M.

Ground lupine, Lupinus bicolor Lindl.

Hairy lotus, Lotus strigosus (Nutt.) Greene

Hansen larkspur, Delphinium Hansenii Greene

Layia, Layia pentachaeta Gray

Linanthus, Linanthus filipes (Benth.) Greene

Locoweed, Astragalus didymocarpus $\mathrm{H}$. \& A.

Loosestrife, Lythrum hyssopifolia L.

Maiden clover, Trifolium microcephalum Pursh

Napa thistle, Centaurea melitensis L.

Navarretia, Navarretia pubescens

(Benth.) H. \& A.

Phacelia, Phacelia spp.

Popcorn flower, Plagiobothrys nothofulvus Gray

Rattlesnake weed, Daucus pusillus Michx.

Red maids, Calandrinia Menziesii $\mathrm{T}$. \& G.

Red-stem filaree, Erodium cicutarium L'Her

Sage, Salvia spp. 


\section{Broad-Leaved Herbs-(Continued)}

Spanish clover, Lotus americanus (Nutt.) Bisch.

Spurge, Euphorbia ocellata D. \& H.

Subterranean clover, Trifolium subterraneum $\mathrm{L}$.

Tomeat clover, Trifolium tridentatum Lindl.

Tree clover, Trifolium ciliolatum Benth.
Turkey-mullein, Eremocarpus setigerus Benth.

White-stem filaree, Erodium moschatum L'Her

White-tip clover, Trifolium variegatum Nutt.

Wright's tarweed, Hemizonia Wrightii Gray

Yellow tarweed, Hemizonia virgata Gray

Shrubs ANd Trees

Blue elderberry, Sambucus glauca Nutt. Blue oak, Quercus Douglasii H. \& A.

California buckeye, Aesculus californica Nutt.

Coffeeberry, Rhamnus californica Esch. subsp. cuspidata (Greene) Wolf

Deerweed, Lotus scoparius (Nutt.) Ottley Digger pine, Pinus sabiniana Dougl.

Hollyleaf buckthorn, Rhamnus crocea

Nutt. var. ilicifolia (Kell.) Greene
Interior live oak, Quercus Wislizenii A.DC.

Mariposa manzanita, Arctostaphylos mariposa Dudley

Poison-oak, Rhus diversiloba T. \& G.

Saltbushes, Atriplex canescens (Pursh) Nutt. and A. nummularia Lindl.

Wedgeleaf ceanothus, Ceanothus cuneatus (Hook.) Nutt.

Species of Filaree.-Of the three species of filaree (known also as alfileria, alfilaria, and alfilerilla) found on the Range, the broad-leaf filaree is by far the most abundant (fig. 5, $A$ ). This species alone comprised from 15 to 42 per cent of the forage cover during the study, being the most common of any forage plant (table 1). Red-stem filaree (fig. 5, $B$ ) is exceedingly sparse on the area, having made up only 0.1 to 3.0 per cent of the plant cover, while white-stem filaree (fig. $5, C$ ) occurs only in small quantities around headquarters.

The filarees, all annuals introduced in early days into California from the Mediterranean region, have become widely spread and now constitute an important part of the range feed. They are well distributed over the range, but generally occur in greatest abundance on south exposures. The seeds are among the first to germinate after the fall rains begin, usually in October. The young plants may make appreciable growth during November if the rainy season is early, but during 8 or 10 winter weeks the plants often turn reddish in color and make practically no growth except leafy rosettes, which may lie nearly flat on the ground. They are shortest on areas grazed heaviest during the previous season. The rosette tendency appears to be slightly less developed in the redstem and white-stem forms; consequently these two species may furnish more feed than that of the broad-leaf during the winter period.

With the advent of warmer weather, usually during the latter part of February or early in March, a central stalk begins to develop and soon 


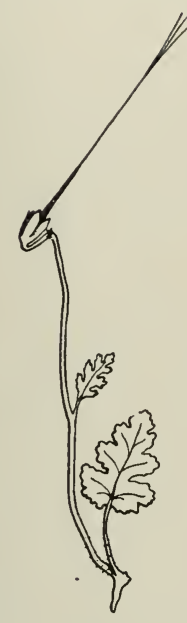

A

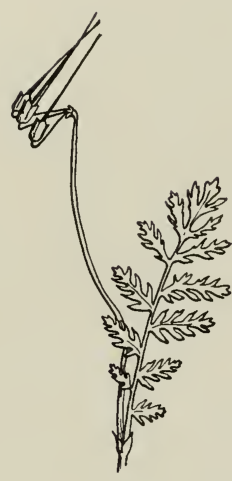

B

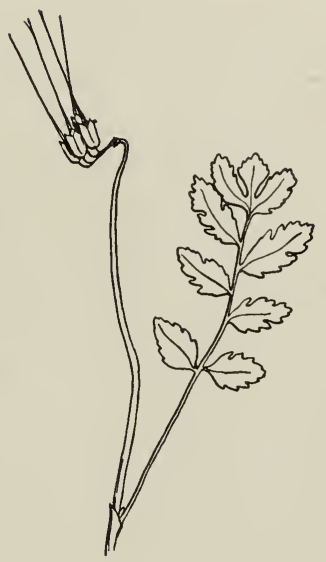

C

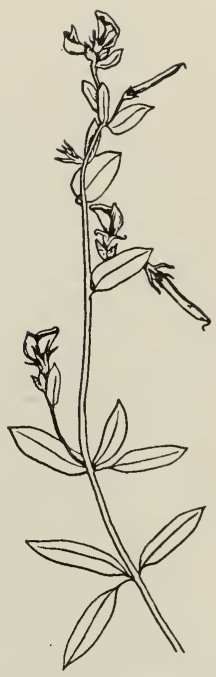

D

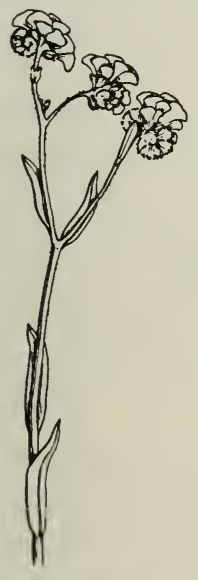

E

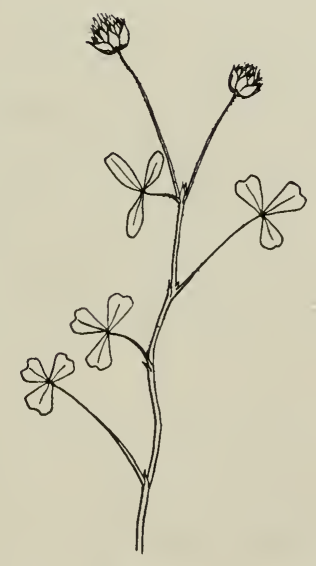

$\mathrm{F}$

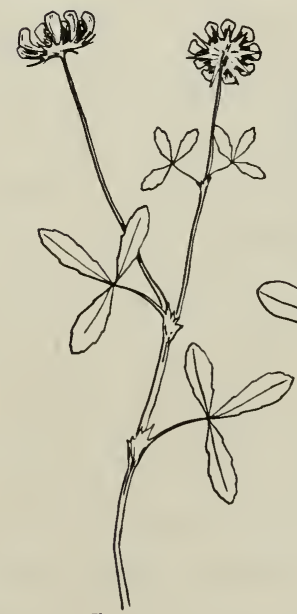

G

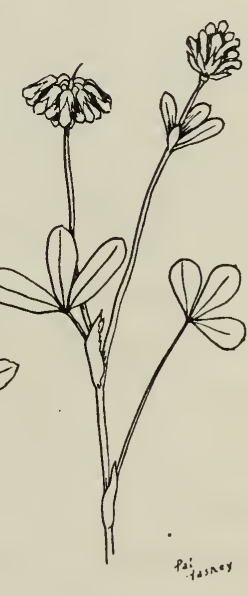

$\mathrm{H}$

Fig. 5.-Eight important broad-leaved herbs occurring on the San Joaquin Experimental Range: $A$, broad-leaf filaree; $B$, red-stem filaree; C, white-stem filaree; $D$, Spanish clover; $E$, popcorn flower; $F$, maiden clover; $G$, tomcat clover; $H$, tree clover.

attains an average height of 5 to 8 inches; but in favorable sites it may reach 18 or 24 inches. In 1935, some plants in favorable spots grew to a height of 36 inches. Flowering and fruiting continue from the time spring growth starts until the plants dry. On south exposures drying usually begins around the middle of April, but on north exposures and 
in moist places a few plants may remain green until late in June. Because of this long fruiting period a fairly good seed crop is likely to be produced if any growth takes place at all. In years when growth is scant and mature plants are small, the fruits or "seeds" may account for about a third or half of the height growth of the plants. Although adverse growing conditions decrease the number of seeds produced, the size of plant appears to be decreased even more. Seed development reaches its peak during a period of 4 or 5 days of very rapid growth around the first of April, when the seed heads increase in length by one-fourth inch to almost an inch per day. This is the period when stockmen often remark that one can "almost see the feed grow." This spurt in growth is a kind of seed-crop insurance, for grazing is not likely to be close enough during this short period to keep pace with seed production.

After the plants have dried, they are very brittle. Stands of filaree, even if protected from grazing, actually decrease in forage density through the summer period, from crumbling alone. Such plots, in 1939, showed a decrease in total forage density from 59 to 48 per cent from April through July. The dominant grass species on these plots showed no decrease in density. On many pastures much more filaree herbage is lost during the summer from trampling than by grazing.

Filaree plants are grazed readily throughout the growing season. They provide considerable fall forage during favorable seasons, but during the average winter, while in rosette form, they furnish very little feed. Fruits in the dough stage are sought by cattle, and when plentiful contribute at that time an important part of their diet. Some intensive studies made by Klugh ${ }^{5}$ during the green-feed period in 1936 showed that broad-leaf filaree was grazed most heavily at this time and comprised over 35 per cent of the feed.

During summer, when the plants are dry, the crumbled remnants of broad-leaf filaree plants are seldom taken by cattle unless the forage becomes exceedingly scarce. Red-stem filaree plants, on the other hand, are not so coarse and stemmy, and portions that remain after crumbling and trampling are taken more readily. Also, Gordon and Sampson (7) found that protein content of the dry material of broad-leaf filaree is not so high as it is in the red-stem species. Analyses showed a considerably lower crude-protein content for awns than for the dry leafage and stem material.

Percentage utilization of broad-leaf filaree was estimated at the end of the grazing season in 1939 on 60 permanent plots distributed over 6 grazing-intensity pastures, to provide key areas to aid in comparing the

\footnotetext{
${ }^{5}$ R. H. Klugh, formerly Junior Range Examiner, California Forest and Range Experiment Station.
} 
degree of grazing, year by year. The plant occurred on 57 of the 60 plots and the measurements showed 86 per cent of this species to be either grazed or trampled down. On only 3 of the plots was any stubble left standing after grazing, and this averaged 2 inches in height. Eighteen of the 57 plots were classified as grazed closely, 27 as moderately, and 12 as lightly grazed. The filaree on the closely used plots was 99 per cent utilized or trampled flat on the ground; that on the moderately used plots, 89 per cent; and on the lightly used plots, 58 per cent. Much of the trampling apparently was done by ground squirrels and other rodents.

Because broad-leaf filaree is an aggressive plant, occurs in abundance, and can be depended on to provide feed under a wide range of conditions, it can well be rated one of the two most important forage species on the experimental area.

Clovers.-True clovers common on the area are maiden clover, tree clover, white-tip clover, and tomcat clover. Six other species of clover have been recorded but none of these is sufficiently abundant at present to be of importance as a forage plant. During the five years of study the combined percentage of the four most common clovers in the forage stand has varied from less than 1 to almost 11 .

The clovers are all native annuals. Their distribution over the range is influenced by moisture content and soil conditions. Maiden clover (also called pinhead clover) is found widely over the slopes and ridges, while tree clover (fig. $5, H$ ) is most common around borders of swales and creeks. Tomeat clover (fig. 5, $G$ ) and white-tip clover grow in wet swales and occur most abundantly in wet years. These two clovers are the ones most frequently noticed on the range, since they grow in almost pure stands. Maiden clover (fig. 5, $F$ ) is the smallest of the four species and does not provide as much forage per plant. It grows to a height of 5 to 8 inches; the others often attain a height of 12 to 14 inches.

Clovers are classed as forage species of high nutritive value, and are taken readily whenever available; stockmen usually expect cattle to do well when clovers are plentiful. Swales of clover are usually grazed so closely that by the end of the season the soil is almost completely bare. Swales remaining wet until late in the season may furnish some especially prized green feed after most of the forage on adjacent slopes and ridges is dry.

Spanish Clover.-Spanish clover (fig. 5, D), sometimes called pea vine, occurred in only minor abundance during any of the five years. It varied in amount from 0.5 per cent, in 1937 , to 4.9 per cent, in 1938 (table 1). This native annual, well-distributed over the range, differs from most of the other forage plants in its ability to make some summer growth. 
The seeds do not germinate so readily as do those of broad-leaf filaree, and the young plants make a slow growth during the winter period. Growth, however, is more rapid for a time around the middle of April after the bulk of the other forage has matured, and continues at a slow rate during the summer. In shallow soils the plant seldom exceeds a foot in height, but in deep soils in swales where moisture is plentiful late in the season, it may grow to 3 feet. The plant produces a slender central stem somewhat resembling a pea vine.

Duration of green summer feed varies with the season. During the four wet seasons of 1935 to 1938, much of the Spanish clover remained green all summer. During the dry spring of 1939, in contrast, some plants on shallow soils of south exposures dried by the middle of May; and even on the best sites only a few plants remained green all summer. Seed pods are developed continuously throughout the summer and seeds are cast over a long period.

Spanish clover is not especially sought by cattle in the early stages of growth, but late in the season when the bulk of the other forage has dried it becomes a choice forage plant and is readily taken even when dry. Its importance on the range lies in the fact that it provides some green feed during the dry summer when it is badly needed. On pastures saved for late-season use, Spanish clover is among the first forage plants to be grazed.

Popcorn Flower.-Popcorn flower (fig. 5, E), a native annual, ranged in abundance from 0.3 per cent, in 1936, to 2.6 per cent in 1935 (table 1). It is widely distributed over the Range but usually is most common on south exposures. Like filaree, it germinates readily after the first rains and, provided the season is early, it may make considerable fall growth. A rosette, formed almost at the beginning of growth, during midwinter remains almost flat to the ground on closely utilized areas. With the coming of warm weather in early spring some of the rosette leaves soon point upward and a flower stalk develops early. This is one of the first plants to flower in the spring and the many blooms produced in favorable years spot the landscape like a scattered skiff of snow. Flower stalks average from 8 to 14 inches high; on good sites frequently 24 inches. The plant begins to dry early and by the first of May is almost completely dry. As the leaves dry they shrivel; most of them soon fall, and leave only a dry stem standing.

Since popcorn flower usually makes considerable early spring growth, it provides feed at a time when it is badly needed. In this habit of growth lies its chief importance. Its green flower stalks are readily eaten by cattle but dry stalks are not grazed.

Yellow Tarweed.-Yellow tarweed (fig. 6, A), also a native annual, 

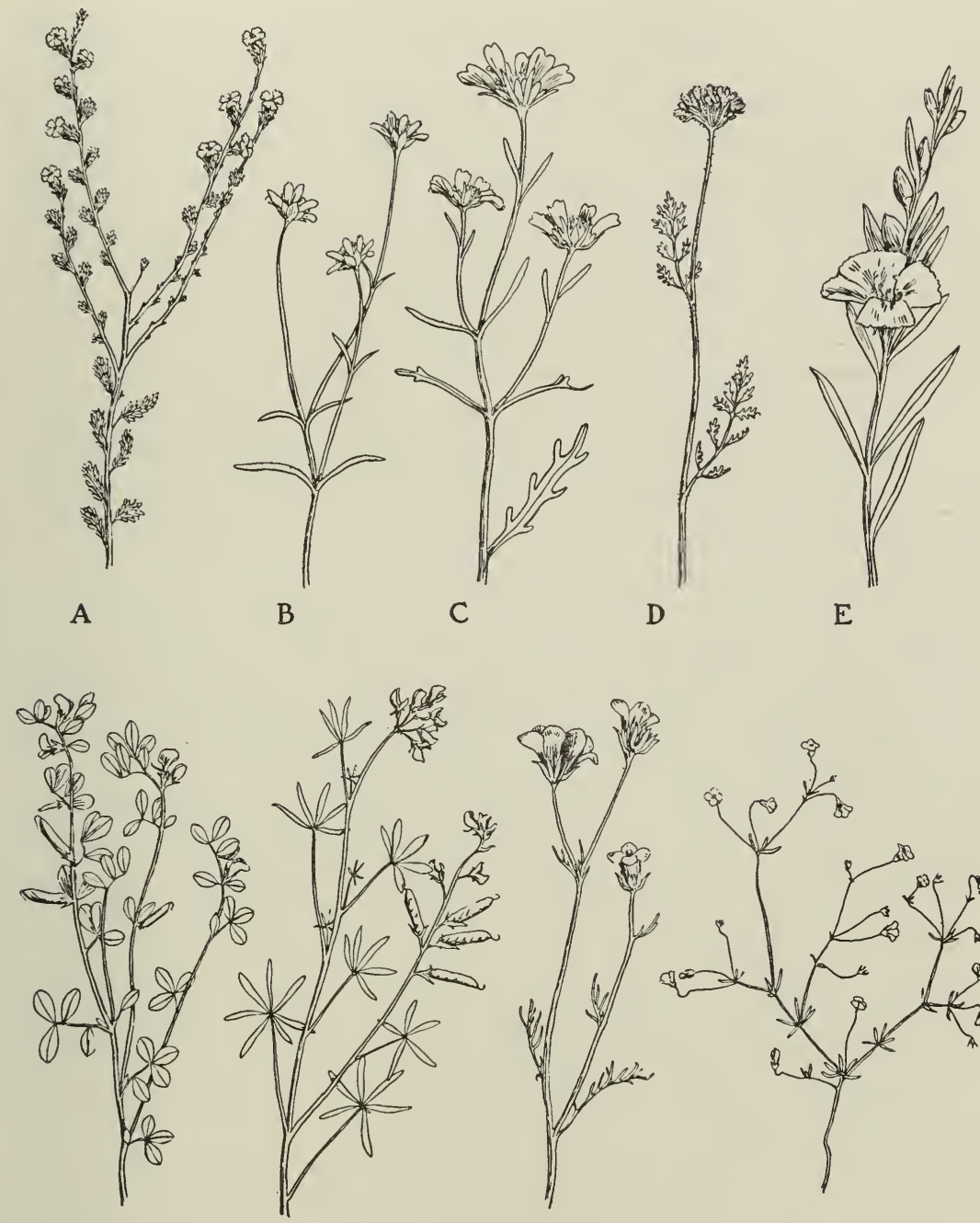

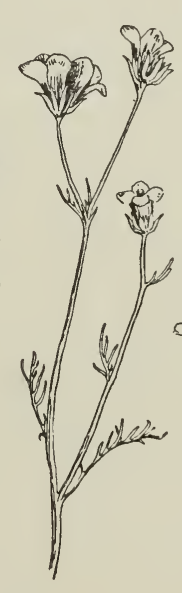

$\mathrm{H}$

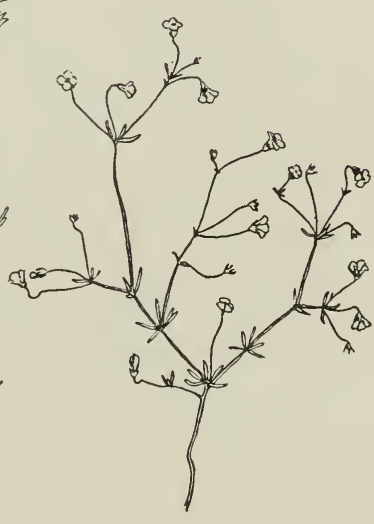

I

Fig. 6.-Broad-leaved herbs of secondary importance on the San Joaquin Experimental Range: $A$, yellow tarweed; $B$, goldfields ; $C$, layia; $D$, rattlesnake weed; $E$, godetia; $F$, fine-leaf lotus; $G$, ground lupine; $H$, birdseye gilia; and $I$, linanthus.

varied in amount from 0.2 per cent to 5.1 per cent during the five years of study. Each year when the forage inventory is made in April at the peak of growth of the forage crop as a whole, tarweed plants are still comparatively small and immature; therefore their amount as represented by the inventory is not fully indicative of the abundance of the plant at maturity. The plants usually average around 10 inches in height and have a spread of about 6 inches. 
Although widely distributed over the range, yellow tarweed is usually most common in swales where the soil is deep. The seeds germinate a few days later than those of filaree and popcorn flower. Growth of the young plants is very slow through winter and the plant is little noticed. Growth speeds up, however, as the bulk of the forage begins to dry around the middle of April, and thereafter the plants rapidly become conspicuous. The plants begin to bloom during the latter part of July and continue to grow throughout the summer. Full bloom occurs during August and September, and drying usually does not take place until after the fall rains start in October or November. During the dry spring of 1939 some plants dried as early as June on south exposures where the soil was shallow, and premature dying continued throughout the summer. A heavy infestation of grasshoppers also killed many tarweed plants in June of 1939.

This tarweed is grazed by cattle with but little discrimination until it is about half grown. Thereafter it is mostly avoided. After it has matured it is rarely taken. It produces a gummy tarlike substance which adheres to the head and legs of grazing animals and to clothing of anyone who brushes against it. Moreover, the plants may grow locally in stands so dense that they interfere with normal grazing.

Yellow tarweed has been occasionally regarded as a possible indicator of range use and condition. As an illustration, an apparent scarcity of this plant on the range may indicate heavy use since it is grazed in the early stages of development. On areas where utilization is close during the green-feed period, any remaining plants are usually spindly, whereas the plants are more robust under moderate and light grazing. Even under close use enough seed is usually produced for another year's crop. Under light use and complete protection the plant gradually decreases in abundance. Trampled areas are favorable to yellow tarweed, as indicated by its increased abundance in old abandoned roads, cattle trails, and other similar places. For this reason a range used heavily one year and protected the next may support a denser stand of tarweed the second year, owing to the trampling of the previous season. In view of these observations, tarweed as an indicator plant must be used with the greatest of caution, especially on ranges that are grazed during the current season.

Turkey-Mullein.-Turkey-mullein, another native annual, was not sufficiently abundant in 1935 to be represented in the forage inventory, and during the following four years it composed less than 0.5 per cent of the total forage cover. However, this summer annual, like yellow tarweed, is still small when the forage inventory is made in April, and is far more conspicuous later in the season. 
On the Range turkey-mullein is most apt to be abundant in places that are grazed off early in the spring. The seeds do not begin germinating until late in December and continue to germinate throughout February, and even into March. The young plants average about threefourths inch both in height and diameter when the bulk of the forage over the range dries in April. At this time many of the seedlings die on lightly grazed areas, probably because the upper soil is so completely dried out by the maturing forage crop. Where much of the forage crop has been removed through heavy grazing the soil is not so completely desiccated, and more of the turkey-mullein plants survive; this apparently accounts in large part for the heavy stands in places that are grazed close early in the season. The average height of the mature plants is nearly 7 inches, and the spread of tops 5 inches-with extremes of 14 to 16 inches.

No grazing of turkey-mullein by cattle has been observed on the Range in any stage of development. Possible indicator value is the chief reason for including a discussion of this species. Abundance on one range and comparative scarcity on an adjoining one may indicate heavy use of the first and light use of the second. However, an abundance of the plant does not always signify that the range has been used heavily. When a heavy rain falls at about the time the main forage crop is at least half dry, the depleted soil moisture may be replenished and the turkeymullein plants survive and become widely conspicuous. This plant, therefore, may also be used to a limited extent as an indicator of range use and condition. Still, like yellow tarweed, it must be so used with caution.

Minor Broad-leaved Species.-Many broad-leaved species other than those already discussed are found in small quantities. Most of these are native annuals. Some of the most common are birdseye gilia, goldfields, layia, linanthus, rattlesnake weed, godetia, ground lupine, and fine-leaf lotus. Some of these are shown in figure 6. As with other species, the relative abundance of these fluctuates up and down from year to year. They are taken along with other forage when young and succulent, but after they mature and dry some are grazed but slightly. The California bur-clover, another introduced annual and one of the most valuable range plants in the annual type, is found only as a trace on the Range, and occurs very sparingly throughout the granite-soil section.

A few native perennials such as the California buttercup, Hansen larkspur, and California poppy make up only about 0.33 per cent of the total herbaceous forage cover. Owing to their scarcity they are comparatively insignificant on the range. Only the California buttercup is worthy of mention as a forage plant. It makes a very early growth and provides some of the earliest feed in several of the swales and other wet 
places. It was $1 \frac{1}{2}$ inches high on the first of February in 1939 when the other feed was only one-fourth inch tall.

Soft Chess.-The most abundant grass on the Range during four of the five years of study has been soft chess (fig. 7, A). During the years 1936 to 1939, inclusive, it made up from 17 to 32 per cent of the cover, although in 1935 it accounted for only a little over 1 per cent. Of the grasses alone, it composed 7 per cent in 1935, 61 per cent in 1937. This grass is widely distributed over the Range, but usually is most abundant on north exposures and in moist places.

Soft chess is an annual introduced from Europe. Its seeds germinate about two days later than those of filaree, provided conditions for germination remain favorable. Fall and winter growth is only moderate. Rapid growth in the spring starts 2 or 3 weeks later than that of broad-leaf filaree; consequently, rains late in the season are much more beneficial to its development. To insure a heavy yield of soft chess, a good rain is almost necessary at about the time filaree has reached maturity. Numerous height measurements of ungrazed plants in the natural area in 1937 and 1939 averaged 6.3 and 5.4 inches, respectively.

On poor sites the plants usually are shorter, but on good sites height growth of 20 to 25 inches is not uncommon. In the spring of 1935, following a very favorable growing season, some plants over limited areas were found to be 52 inches high. When the plants are small and stunted the seed heads also develop poorly.

Soft chess is considered about the best of the annual grasses in this plant type. In areas where broad-leaf filaree makes up a high percentage of the plant cover it seems that the crop is better for yearlong grazing where soft chess makes up at least 20 or 25 per cent of the cover. For the season as a whole, it might well be considered one of the two most important forage plants on the Range, being equalled or surpassed only by broad-leaf filaree. During the summer it has thus far been rated as the most importan' forage plant in the area. Soft chess also provides considerable winter feed but is grazed most heavily at the time it is reaching maturity, just after broad-leaf filaree has begun to dry. In 1936, for example, it composed nearly 60 per cent of the forage at this growth stage. The seeds do not shatter readily and the plants are grazed extensively during the summer. Because of this, the grazing animals get more nutriment than they otherwise would from the dry stalks and leaves alone.

The percentage utilization of this species was estimated at the end of the grazing season in 1939 on the 60 permanent plots. Soft chess was present on 59 of the 60 plots and the measurements showed 55 per cent of this species to be grazed down to an average height just short of 2 


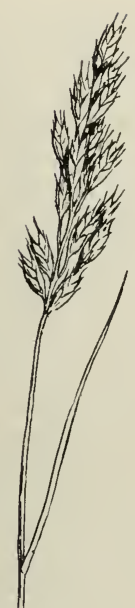

A

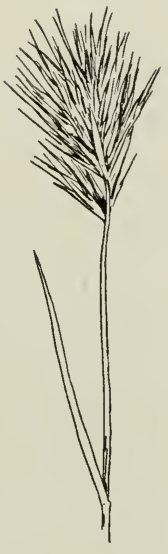

B

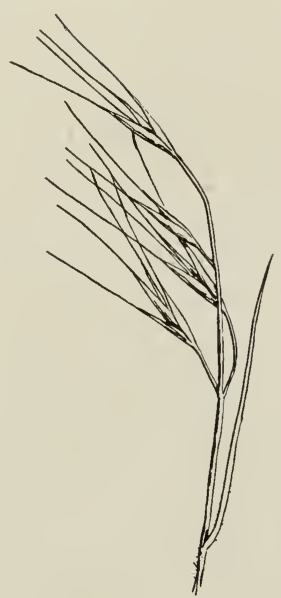

C

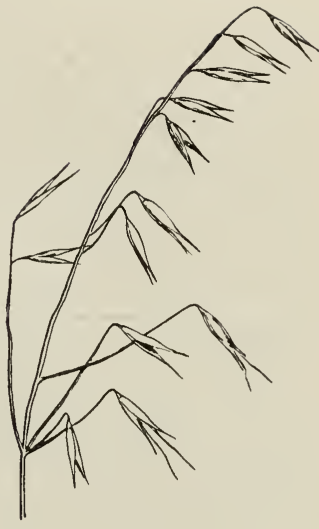

D

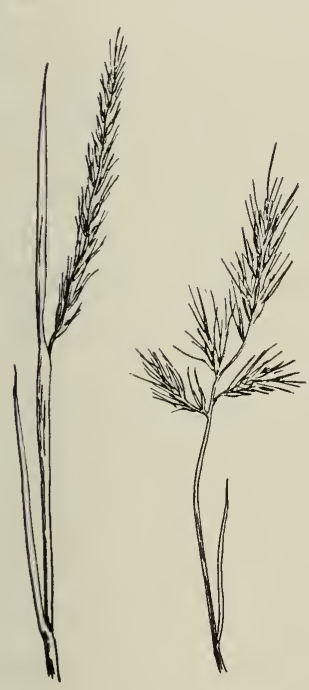

E

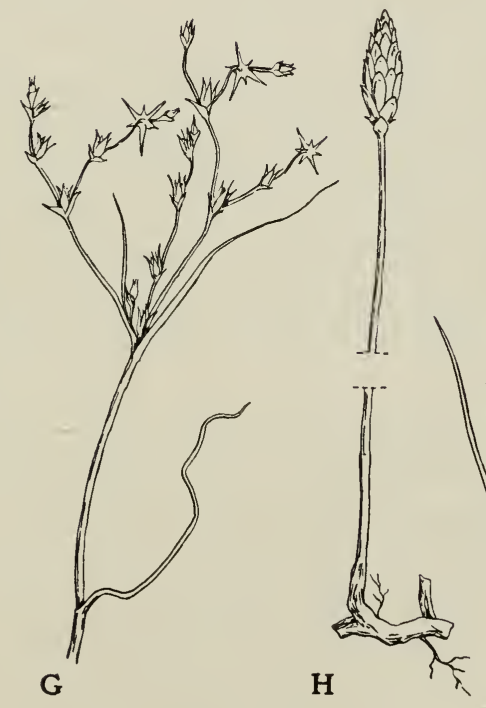

$\mathrm{H}$

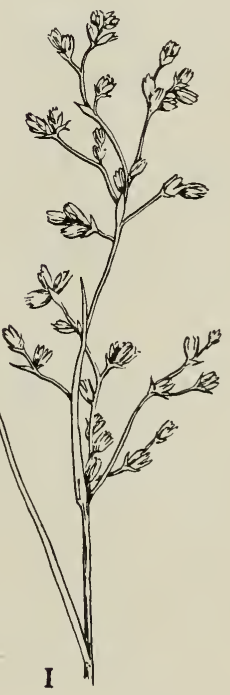

Fig. 7.-Important grasses and grasslike plants on the San Joaquin Experimental Range: $A$, soft chess; $B$, red brome; $C$, ripgut grass; $D$, slender oat; $E$, foxtail fescue; $F$, poverty fescue; $G$, toad rush; $H$, common spike rush; $I$, slender-leaf rush.

inches. This amount of utilization appears in the field to be about moderate use. The 59 plots on which this species was found were classified as to whether they showed close, moderate, or light use. According to this classification 20 of the plots were closely used, 27 moderately used, and the remaining 12 were used only lightly. The plots showing close 
utilization had 80 per cent of this species grazed down to about $11 / 2$ inches. Those showing moderate use had 50 per cent grazed down to about 2 inches; and of the 12 plots that appeared to be lightly used, only 28 per cent of the forage showed use and the stubbles that remained were slightly over 2 inches high.

Foxtail Fescue.-The second most common grass on the Range is foxtail fescue (fig. $7, E$ ), which composed from about 9 to 17 per cent of the total cover during the five years (table 1 ). It accounted for 69 per cent of the grasses in the spring of 1935 when soft chess was scarce, although during the following four seasons it composed only 18 to 40 per cent.

Foxtail fescue is a native annual. The plants are evenly distributed over the range and appear to be especially well adapted to shallow soils. Its seed and those of soft chess germinate at about the same time. The stems are slender and the forage never becomes sufficiently coarse to make it undesirable for cattle. Compared with soft chess, foxtail fescue is shorter and ripens and dries a little earlier-almost as early as broadleaf filaree. The seeds shatter readily; very few remain on the plants by the end of the summer.

Foxtail fescue, the third most abundant species of all plants on the area, is fairly palatable to cattle during all seasons of the year. During the dry summer it ranks next to soft chess. It composed a little over 30 per cent of the forage taken in February of 1936 in one study on utilization. Its use began to diminish in March when filaree and soft chess began to make more growth, and it continued to decrease through April and May. By the middle of May it composed only 5 per cent of the forage taken.

This species was found on 52 of the 60 utilization plots and the measurements showed 59 per cent of the forage to be grazed down to an average height of about $13 / 4$ inches. This amount of utilization has been rated as about moderate use. Of the 52 plots where foxtail fescue was found, 19 showed close use, 23 moderate use, and 10 light use. Those grazed closely had 82 per cent of the foliage of this species grazed down to an average height of less than $1 \frac{1}{2}$ inches ; those estimated to be grazed moderately had 53 per cent grazed down to about $13 / 4$ inches; and on the 10 plots that showed light use, only 29 per cent of the foxtail fescue showed any grazing at all-with an average height of just over 2 inches.

Minor Grass Species.-Grasses other than those already discussed are relatively sparse on the Range. Slender oat (also known as slender wild oat), an introduced annual, is fairly common but in none of the five years has it composed more than 4 per cent of the cover (table 1). It is illustrated in figure $7, D$. Over the foothill section in general this is one of the most common range plants. It is considered good forage during the 
winter period when it makes more growth than many of the other species, especially in protected places, but during the summer when the forage is dry it is not taken very well.

Ripgut grass (fig. 7, C) makes considerable winter growth during which time it furnishes good forage, but after it has dried the plant is not taken readily. The awns are long and rigid and often cause trouble to grazing animals. For this reason it is usually considered an inferior species on the range.

Red brome (fig. $7, B$ ), also commonly known as foxtail chess, is another introduced annual; it comprised 3 per cent or less of the forage cover. This species is fairly well distributed and, like foxtail fescue, appears to be well adapted to shallow soils. Its growth during the winter is about like that of soft chess and it furnishes fair feed during this time. It matures early, at about the same time as foxtail fescue, and after it is dry it is not well liked by cattle. The awns are rather rigid but they are not especially injurious.

Poverty fescue (fig. $7, F$ ), one of the least abundant of the annual fescues, is common on the Range but makes up only a small portion of the cover-never more than about 1 per cent. This species is commonly associated with foxtail fescue and is similar in growth and value. Stock graze the two species together without discrimination.

Common foxtail, also called mouse barley and wall barley, is sparse on the Range but is abundant over many areas in the annual type. Stockmen regard it as a good forage plant during the winter, when it makes considerable growth. After it dries, it is a decidedly inferior forage, because of the troublesome awns.

Pine bluegrass is a native perennial. Even though it makes up a very small percentage of the cover, it is the most common perennial grass on the Range. It has composed less than 0.2 per cent during each of the five years of study. Other perennial grasses which are exceedingly sparse are melic grass and purple needlegrass (also known as California needlegrass and nodding needlegrass). Bunches of melic are confined chiefly to rock outcrops. These perennial grasses have not increased on this area during the past five years, either under grazing or total protection.

The perennial grasses now occurring on the range as a whole are mainly dormant through the dry summer period. They dry almost as early as do the bulk of the annual species, and then become green again after the start of the fall rains. Pine bluegrass, in particular, dries very early and none of the top remains green during the summer. Drying of purple needlegrass is delayed nearly 2 or 3 weeks later and a little greenness may remain in the base of the clump practically all summer, although the amount of such green feed is small. 
Cattle graze pine bluegrass, both green and dry, much as they do the annual grasses. Its organic constitutents are similar to those of annual grasses ( 7 ). From these and other observations on growth and utilization, the advantages of the native perennial grasses are chiefly two: They make more fall and winter growth than annuals, and they can be relied on to make grazeable fall growth with less moisture.

Grasslike Plants.-The grasslike plants, or rushes, (fig. 7) are comparatively sparse on the Range. The three most common species are slender-leaf rush, common spike rush or wiregrass, and toad rush. The first two are perennials; all three are natives. Even though the two perennials together have composed only 0.5 per cent or less of the cover each year, they are rather important grazing plants for a short time at the end of the green-feed period. They are found chiefly in the wettest swales and usually remain green for a time after most of the annuals have dried. It is during this time that rushes are grazed most heavily by cattle and are most important on the range; for example, in 1936 they made up well over 15 per cent of the feed for a short time near the middle of May. In the dry spring of 1939 they dried early and therefore furnished little feed at this season.

Toad rush (fig. $7, G$ ) varied in amount from 2.8 per cent of the forage cover, in 1935, to nothing in 1939. Like the perennial rushes, this species is found mainly in wet places, and the season of 1939 was a dry one. When this species is plentiful it is most common on heavily grazed and trampled areas, everything else being equal, and therefore it may be considered as an indicator of heavy grazing, or of other disturbance. The plant is grazed readily when it is green but only moderately after it has dried.

Browse Plants.-Shrubs commonly browsed on the Range (fig. 8), listed in order of amount of feed they provide on this particular area, are: wedgeleaf ceanothus, also variously known as buckbrush, chamise, chaparral, and greasebush; hollyleaf buckthorn, locally often called redberry ; coffeeberry, also called California buckthorn; blue elderberry, known also as blueberry elder; poison-oak; and Mariposa manzanita. In order of their palatability they are rated thus : blue elderberry, coffeeberry, hollyleaf buckthorn, poison-oak, Mariposa manzanita, and wedgeleaf ceanothus. Three tree species commonly browsed, both in order of amount taken and their palatability, are the California blue oak, interior live oak (also known as highland live oak), and California buckeye. The first of these trees probably furnishes more browse than any of the shrubs on the Range. It is estimated that the shrubs and trees together roughly cover, on the average, from 10 to 15 per cent of the Range area; at higher elevations the proportion of browse plants is greater. 


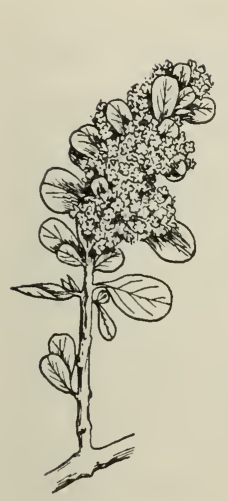

A

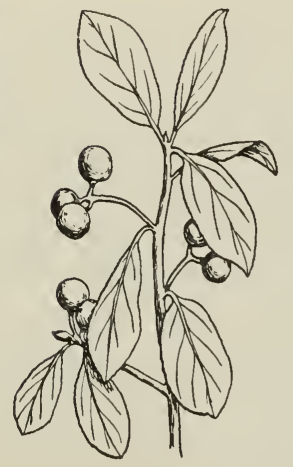

B

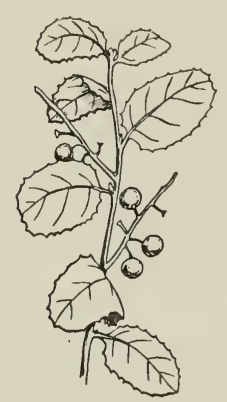

$\mathrm{C}$

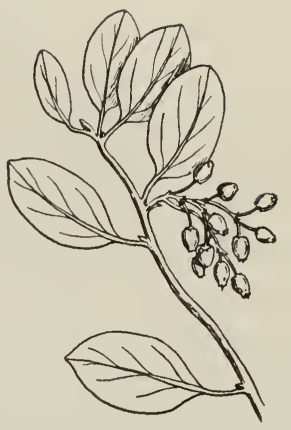

D
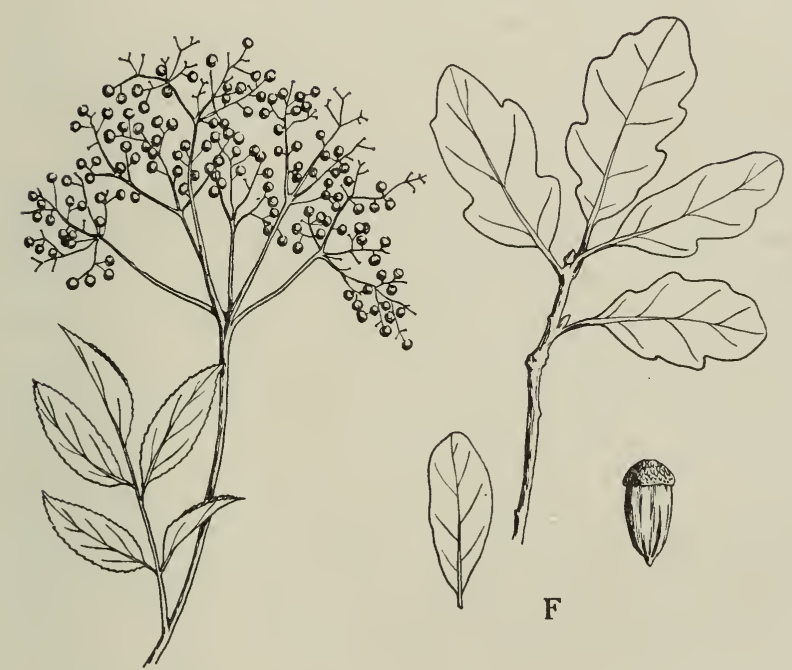

$\mathrm{E}$

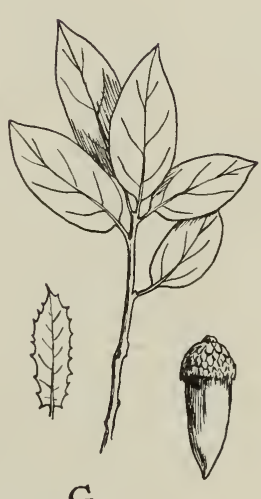

G

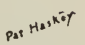

Fig. 8. - Seven shrubs and trees commonly browsed on the Experimental Range: $A$, wedgeleaf ceanothus ; $B$, coffeeberry; $C$, hollyleaf buckthorn; $D$, Mariposa manzanita; $E$, blue elderberry; $F$, blue oak; $G$, interior live oak.

It is difficult to estimate the value of these browse species on the range. Even though they do not furnish a large quantity of feed, probably not exceeding 1 or 2 per cent year after year at the experimental area, they do provide some green material during the summer when the herbaceous forage is mainly dry; thus they help out on protein, and possibly vitamin A $(11,12)$. This, no doubt, is their chief value on ranges where they compose only a small part of the diet. A few browse species on any range are highly desirable plants. 


\section{GROWTH AND DEVELOPMENT OF THE ANNUAL FORAGE CROP}

In planning his ranch enterprise the skillful operator considers carefully the times when forage grows and is available for grazing. The forage crop on this area passes through three distinct phases each year : (1) Seeds germinate and growth starts shortly following the first effective rains of the season (expected in October) but is usually very slow during 3 or 4 months of the mild winter, being retarded mostly by low temperatures but occasionally by insufficient rainfall. (2) Rapid growth starts during the latter part of February or early in March and terminates near the end of April. The forage is of most value to livestock during this period of rapid growth. (3) The mature crop dries rapidly during May and June and remains dry throughout the summer-a period of nutritive deficiencies which must be considered in management. The dry-feed period extends through the summer and until such time as the first autumn rains of the next rainy season start growth of a new forage crop. These three phases, and their bearing on practical handling of the range, are discussed under their separate headings.

Fall and Winter Period of Slow Uncertain Growth.-Annual plants in this type of range make very little growth during the months of December, January, and February. Consequently, the supply of new forage during this period is generally not sufficient to maintain animals without additional feeds. When the first good rains are fairly early, for example in mid-October, before the temperatures become low, there may be considerable growth in the fall; but the amount produced is usually not sufficient to carry the animals through the ensuing winter weeks. Winter growth is usually a little greater if the fall rains are early, everything else being equal, since the plants are better established and the increased top growth offers protection against cold.

Height measurements from both protected and grazed plots, as shown in table 2, afford an illustration of the slow rate of growth of range forage during the three winter months: December, January, and February.

During the fall and early winter, perennial grasses and rushes make more growth than annuals. This observation is illustrated by some measurements taken in January, 1939. Clumps of pine bluegrass were 2.5 inches high and California melic averaged 10.3 inches, whereas the average height of soft chess on 60 permanent plots at this time was 1.4 inches, foxtail fescue was 1.4 inches, and broad-leaf filaree only $0.5 \mathrm{inch}$. Perennial grasses thus provide, in proportion to their abundance, more fall and early winter feed than the annuals.

Early Spring Period of Rapid Growth.-Most growth of annuals takes 
place in about 6 weeks following the first of March. Usually there is plenty of moisture at this time and rising temperatures further stimulate growth. An illustration of the accelerated growth during this period appears in table 2 ; the measurements were made on the same species and plots as those given for the winter period. All three species had reached maturity by April 20. Therefore, during the period from March 1 to April 20 broad-leaf filaree, on the two sets of plots combined, made 83

TABLE 2

Winter and Spring Growth of Three Main Forage Species, 1938-39

\begin{tabular}{|c|c|c|c|c|}
\hline \multirow[b]{2}{*}{ Range use } & \multirow[b]{2}{*}{ Date } & \multicolumn{3}{|c|}{ Height in inches by species } \\
\hline & & $\begin{array}{l}\text { Broad-leaf } \\
\text { filaree }\end{array}$ & $\begin{array}{c}\text { Soft } \\
\text { chess }\end{array}$ & $\begin{array}{l}\text { Foxtail } \\
\text { fescue }\end{array}$ \\
\hline \multicolumn{5}{|c|}{ Winter growth } \\
\hline Protected against livestock.... & $\left\{\begin{array}{l}\text { December } 1 \\
\text { March } 1\end{array}\right.$ & $\begin{array}{l}0.4 \\
0.7\end{array}$ & $\begin{array}{l}1.5 \\
2.0\end{array}$ & $\begin{array}{l}1.3 \\
1.6\end{array}$ \\
\hline Grazed by livestock............. & $\left\{\begin{array}{l}\text { December } 1 \\
\text { March } 1\end{array}\right.$ & $\begin{array}{l}0.4 \\
0.8\end{array}$ & $\begin{array}{l}1.2 \\
1.5\end{array}$ & $\begin{array}{l}1.1 \\
1.3\end{array}$ \\
\hline
\end{tabular}

Growth during six weeks of spring

Protected against livestock................

per cent of its height growth, soft chess made 68 per cent, and foxtail fescue 74 per cent. Although there is considerable variation from year to year, it appears that beginning of rapid growth cannot be expected much before the end of February or first week in March.

On ranges that are stocked on a yearlong 'basis there is usually no scarcity of feed at this time of year. The forage grows far faster than the animals are able to utilize it. Where feeder cattle are shipped in, in order to utilize the forage during the green-feed period, the situation may of course be different. As the feed becomes more abundant during this period of rapid growth, cattle begin to do some selective grazing. Livestock gain rapidly during this period since the forage crop as a whole is lush, nutritious, and ample.

Summer Period of Greatest Feed Deficiencies.-The forage crop is exceedingly poor in nutritional qualities after it has dried and weathered. Hart, Guilbert, and Goss (13) and Wagnon, Guilbert, and Hart, in the section "Experimental Herd Management," have shown crude pro- 
tein to be the chief deficiency as far as cattle are concerned. The crudeprotein content of young plants is high but it decreases rapidly as the plant grows, according to Gordon and Sampson (7), and Guilbert and Rochford (10), until it reaches the full-bloom stage. Afterwards the percentage of crude protein decreases slowly until it is very low when the forage has dried and weathered. Hart, Guilbert, and Goss (13) state that phosphorus also may become deficient in some years under certain conditions. A detailed discussion of these deficiencies, and of their significance to the grazing animal, will be found in the section mentioned above.

There are some exceptions to these general statements regarding the decreased value of the range forage plants in summer. A few species such as Spanish clover and perennial rushes, being late growers, furnish some green feed until late in the season or, in some years, practically all summer ; they thus help out on the crude-protein-deficiency problem. Nevertheless, as explained in another section, the amount of these plants is not sufficient to balance the ration and provide for normal animal nutrition.

\section{VARIATIONS IN THE FORAGE CROP FROM YEAR TO YEAR}

In practical ranch operation the stockman is ever troubled by the uncertainty of range forage. In the annual-plant types, big differences in the crop from year to year are the rule-not the exception. Owing to the size of these differences, to their uncertainty, and to the fact that they cannot be predicted far in advance, proper stocking of ranges is extremely difficult. Consequently, fluctuations in yield, mixture of species, and time of growth add up to one of the biggest problems facing livestock operators in these foothills.

Changes in Yield of Forage.-The total yield of forage varies noticeably from year to year, and occasionally extreme fluctuations take place. It is a common observation that these variations are generally greater in the annual-forage type than in perennial-grass types.

It is estimated that variations amounting to nearly twice as much feed one year as compared with another have occurred on portions of the Range during the period covered by these preliminary studies. Differences of fully 50 per cent have been recorded in the fenced pasture plots, weights of forage clipped from small areas in these ungrazed plots being equivalent to $1,460,1,010,1,490$, and 1,570 pounds per acre for the years of $1935,1936,1937$, and 1939 respectively. Forage production during these years probably has been above that of a long-time average, since conditions for growth (particularly precipitation) have been exceptionally good; and 1935 was considered by old residents as the most productive in many years. 
These fluctuations are not unusual in the grazing lands in California that are covered with annual plants. Far greater differences in yield between consecutive years were reported by Talbot, Biswell, and Hormay (14) in the southwestern part of the San Joaquin Valley for the years 1934 and 1935. The season of 1934 was very dry, and growth conditions were so adverse that practically no forage was produced over large areas. The following season, with an abundance of well-distributed rainfall and with favorable temperatures, livestock grazed over the same areas in feed literally "knee deep."

Changes in Kinds of Range Plants.-In this annual type, not only the amount but also the kind of forage varies. As already pointed out and shown in table 1 , the percentage of most species on the Range during the five years of study varied widely at the peak of growth; however, a few have held fairly constant. As a result the range feed as a whole is better some years than others, a fact that reflects differences in palatability and nutritional qualities of the various plants, and also supports a common observation of local stockmen that "this is a poor bur-clover year" or "a good bur-clover year"-according to the current abundance of this superior forage plant. Also, table 3, based on annual inventories, shows how several groups of the range vegetation vary from year to year. Further evidence is diagrammed in figure 9, which also emphasizes the surprising degree to which alien plants have invaded range lands of this region.

It is an interesting observation that several kinds of plants appear to make parallel fluctuations. The behavior of the legumes to date illustrates this tendency. When proportions of the clovers have been high in the plant cover, the percentages of Spanish clover, fine-leaf lotus and lupines have also been relatively high; and when one of these groups has been low, the others have been also. A similar type of fluctuation was noticed with several species of grasses, as well as with the grasslike plants. Apparently the growth factors favoring one species or group is also favorable to the others and, as a result, a similar response is made by all. Also, fluctuations by groups tend to cause corresponding shifts in the average forage density over the range. It has been noticed particularly that a shift up or down in the legume group will cause a similar shift in total density, since most of the legumes represented in the plant cover have a dense spreading habit of growth.

The number of species making up an appreciable part of the flora also varies considerably from year to year. For example, in 1935 the number of species each making up 1 per cent or more of the forage crop was 16 ; in 1938,14 ; in 1939, 10 ; and in 1936 and 1937 the number was only 7 .

But little information has been obtained thus far concerning fluctuations that extend over a long period of time. However, indications are 
that the percentage of some species varies with long-time wet and dry periods.

Variations in Time of Growth and Drying.-Growth dates vary widely from year to year-a general observation confirmed by numerous measurements. In 1934, growth was abundant in the autumn and continued well through the winter; in 1937, fall and early winter growth was practically nil. During the fall and winter of the years 1935, 1936, and

TABLE 3

Fluctuations Between Plant Groups from Year to Year

\begin{tabular}{|c|c|c|c|c|c|}
\hline \multirow{2}{*}{ Plant group } & \multicolumn{5}{|c|}{ Percentages by years } \\
\hline & 1935 & 1936 & 1937 & 1938 & 1939 \\
\hline Annual broad-leaved plants...... & 74.8 & 53.2 & 43.5 & 61.7 & 52.6 \\
\hline Annual grasses.............. & 20.6 & 45.5 & 55.5 & 34.1 & 47.1 \\
\hline Annual grasslike plants.............. & 2.9 & 0.5 & 0.5 & 3.6 & Trace* \\
\hline Total................. & 98.3 & 99.2 & 99.5 & 99.4 & 99.7 \\
\hline
\end{tabular}

* A trace is less than one-tenth of one per cent.

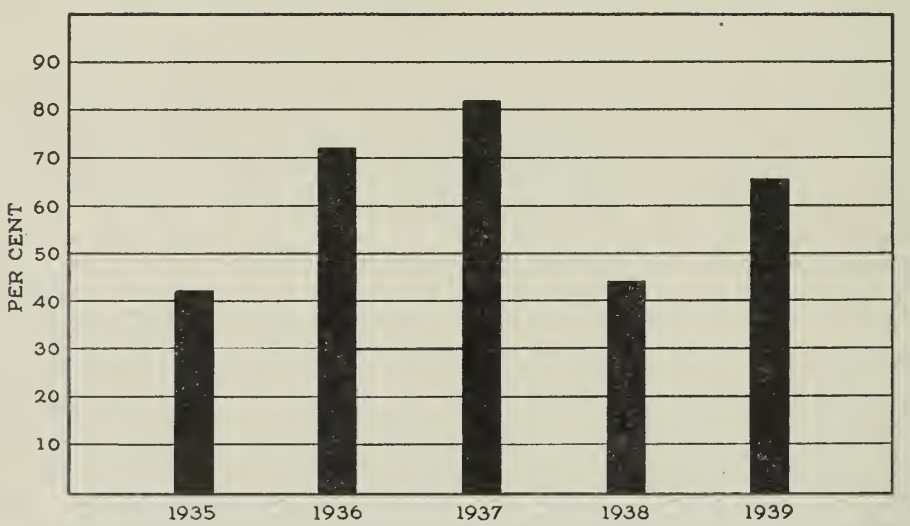

Fig. 9.-Variable percentage of total forage represented by alien plants.

1938, plant growth was moderate. The period of rapid growth during the spring varied by about one full month. In 1935 and 1936 rapid growth began during the last week of February, while in 1938 it was exceptionally late, not beginning until the last week of March. In the spring of the years 1937 and 1939, rapid growth began about the first of March.

The length of time that the forage crop is dry and low in crude protein also varies from year to year, which complicates supplemental feeding. The forage may dry earlier some years than in others; and new feed comes later some years than others, according to the occurrence of fall 
rains. Drying at the end of the season took place at about the same time during the four years 1935 to 1938 ; but in the spring of 1939 drying on south exposures was nearly 3 weeks earlier than for the four preceding years, and in swales the difference in time was still greater. Data collected in 1938 and 1939 from permanent plots located on south exposures illustrate the wide differences in time of drying. Soft chess, for example, in 1938 was only 33 per cent dry on May 15, whereas in 1939 it was 58 per cent dry by April 28. Foxtail fescue on the same plots was 90 per cent dry by May 15 in 1938, and was 84 per cent dry on April 28, 1939. Drying of forage in the swales in 1939 was only a little later than it was on most slopes, but during the wet seasons of 1935 to 1938, inclusive, the swales were wet until late in the season and the forage was correspondingly late in drying. During the years of heaviest precipitation there was still some green feed in the wettest swales in mid-June.

These wide fluctuations in forage produced from year to year necessitate careful and skillful operation on the part of the stockman, in providing supplemental feeds or additional acreage during adverse seasons, and in other ways keeping his business as flexible as possible.

Conditions That Bring About Forage Variations.-Climatic factors no doubt have most to do with yearly fluctuations in forage yield, composition, and season of growth. Precipitation and temperature are the most important, and a scasonal variation in either may cause a marked fluctuation in the feed. The close tie between climatic factors and forage growth has encouraged the thought that certain characteristics of the forage may be predicted some time in advance of their development. Evaluation of the more complex relations awaits further study, but certain promising trends are already beginning to take shape.

It appears that about 0.8 inch of rain is sufficient for the germination of a normal stand of annuals, the required amount depending somewhat on such factors as humidity, temperature, cloudiness, and wind. Under the same conditions of weather, less rain will start growth of perennial grasses and rushes. These began to grow following a rain of 0.25 inch in the fall of 1937; and other light showers up until November 23-all totaling 0.5 inch-were enough to maintain their growth.

With favorable conditions, annuals usually germinate very quickly. One year, new seedlings were coming up within 41 hours after the start of fall rains and repeated observations have shown that warm slopes will begin to take on a green cast within only 3 or 4 days following the start of rains. Cattle will begin to graze the new growth within a few days, although for some time the volume of new green feed may be insufficient to maintain the animals.

The percentage of each species in the mature forage cover is influenced 
somewhat by the time the first rains occur. When the rains are early, conditions usually favor the germination of certain species; while late rains bring about the germination of other kinds of plants. This was first observed through greenhouse and plant-nursery experiments and later verified in the field. Some broad-leaf filaree plantings made in the unheated greenhouse in December of 1936, after temperatures had become fairly low, yielded very low germination percentages, but in the early warm fall of 1937 a good stand was obtained from a similar planting. Broad-leaf filaree plantings made in the forage nursery late in the season also yielded a poor stand the first season. Similar behavior was observed in the field in the fall of 1937 when the first effective rains did not occur until December 9. The percentage of broad-leaf filaree, and also of soft chess, was low in the forage cover the following season. Several other species, mainly natives, were more abundant. If this relation continues to hold true, broad-leaf filaree and soft chess are likely to be abundant when the first effective rains are early, provided of course there is a good seed supply of each in the soil and a drought period does not follow the first rains. When the first rains are late (December 10 or later) these species are likely to be comparatively sparse.

When the rains are late a greater number of species are likely to be found in the forage cover, common examples being some of the clovers, lotus, and lupines. One acquainted with seedlings can usually make a fairly close guess early in the season as to what the abundance of certain species in the forage cover in the spring will be. Obviously, this cannot be done with any high degree of accuracy since the plants respond differently to varying climatic growth factors.

Good plant growth usually follows the first effective early rains. Dry periods may follow, however, and cause the feed to cease growth almost completely, or in some cases even cause the death of many plants. In the fall of 1934, the first effective rains were not especially early but growth throughout the fall was excellent since the rains kept up and moisture was sufficient. Growth in the fall of the years 1935 and 1936 started early but dry periods which followed and lasted until the middle of December brought it almost to a standstill. Growth was excellent for a short time following the first rains in the fall of 1939, but the ensuing period of clear dry weather stopped growth; and most of the plants on south exposures died.

After the first of April, rainfall no doubt becomes the most critical factor in growth. The maturing vegetation requires considerable moisture as the days lengthen and temperatures increase. Rainfall during the latter part of March and first of April may determine largely the amount of forage produced. In the spring of 1939, plant growth was slowing 
rapidly prior to March 26 and 27 when a total of 1.28 inches of rain fell. This was sufficient to cause continuation of growth and a good forage crop developed. Had it not been for this rain, soft chess probably would have made little growth and developed little seed since it matures late in the season.

During wet years some forage in the swales may stay green nearly 2 months after the vegetation has dried elsewhere and thereby the length of the green-feed season is increased. This was the case during the four wet seasons of 1935 to 1938, when there was heavy seepage into the swales. In many places the perennial rushes provided green feed until the middle of July, and in 1935 some plants were still green even at the middle of August. In contrast to this the feed in the swales in 1939, following the dry winter season, dried only little later than it did on the ridges, being mostly dry by the middle of May and almost completely by the first of June. Cattle graze heavily on the green feed in the swales late in the season, and as long as they get sufficient quantities of this, protein supplements are not needed. Therefore, spring rains sufficiently heavy to cause seepage until late in the season are of value and may be expected to extend the green-feed period and thus delay for a time the critical period of dry feed.

Heavy rains after the bulk of the palatable vegetation has matured and dried, and is not using soil moisture, are a boon to the summer-growing species such as yellow tarweed, turkey-mullein, and Spanish clover. In 1935, a rain of 1.76 inches coming on April 29 partly explains why yellow tarweed in some places attained a height of 6 feet and the Spanish clover remained green all sumer. Again, yellow tarweed and turkeymullein plants were very abundant and moderately large during the summer of 1938 as a result of heavy rains late in April. During the seasons of 1936 and 1937 when the rainfall was light through the latter part of April the summer-growing plants were sparse and only of moderate size. In 1939, when practically no rain came during all of April and the soil was left dry as a result of the forage crop maturing, most all summer-growing species died early in the season. Only a few turkeymullein plants remained along creeks, where the soil was deep, and in other places where the forage crop was grazed off before the soil moisture was depleted.

Rains - even light showers-coming late in the season after most of the forage has dried are usually harmful to the dry feed through leaching (13). For example, it was the general consensus of opinion that a rain of only 0.15 inch in May 1936 had this effect.

In summarizing the several climatic factors that leave their mark on forage, two stand out-and they operate together. Rain in itself, im- 
portant as it may be, is not the determining factor, for it operates in relation to temperature. It is possible to have, for example, a better forage crop with 10 or 12 inches of rain well distributed and combined with favorable temperatures, than with 25 or 30 inches of rain with unfavorable distribution and temperatures. The study period has not yet included any bad drought years. So this "annual type," which to the casual observer appears to be a simple type, is actually a very complex one.

As in other branches of agriculture, any forecasts of conditions would be helpful in arranging the complicated range livestock business. To be able to know, in advance, of impending shortages in range forage would give the operator a greater chance to provide supplemental feed, adjust herds, or arrange credit facilities to carry him over the unfavorable periods. As more is known about the effects of weather on feed (for even a short period in advance) the operator may be better equipped to deal with the changes and uncertainties of feed that prevail in this type of range; for the relation between climate and feed bears directly on the everyday questions of proper grazing season and intensity of use.

\section{EFFECTS OF DIFFERENT INTENSITIES OF GRAZING}

The many practical problems of forage management in the annual type in need of study include the effects of different intensities and seasons of grazing, the possibilities of improvement by artificial reseeding or through fertilizing or other soil treatment, and the effects of different uses and treatments on rainfall runoff. Most of the foragemanagement studies reported upon in this bulletin concern chiefly the effects on the range of different intensities of use-what happens, for example, when this type is grazed heavily or lightly. The question uppermost in many stockmen's minds is: "How can I graze my range to get the most out of it and still not hurt it? And if possible, improve it?"

Since the measured effects of different degrees of use of annual-type ranges were little known when the San Joaquin Experimental Range was started, this was considered one of the major studies. Its aim is to find out just what the relation may be between the closeness and period of grazing a range and the kind, amount, and duration of forage which it produces. Concrete facts on such problems bear directly on one of the fundamentals of successful ranch operation.

A set of pastures was established for beginning the study. It consists of two small, two medium-sized, and two large pastures (fig. 1), all stocked with the same number of cattle for approximately 7 months of the year. Each pasture is grazed by 15 cows with their calves to weaning time, together with a bull for nearly 4 months of the period. The average number of calves produced per pasture is about 9 , so figuring each of 
these as one-half animal unit, the pastures were stocked during the three years of 1937-39, inclusive, at the approximate rates of 9,14 , and 18 acres per animal unit for 7 months. This stocking has been followed during the seasons of 1937,1938 , and 1939 , so the pastures have been grazed at these rates for only three years. The livestock are usually turned on in January, as soon after the first of the year as the feed is sufficiently far along to carry them without much weight loss, at least in the middle-sized pastures. They are usually removed early in August, after the feed has become short in the small pastures and the animals have begun to lose considerable weight. During the remaining 5 months the cows are in pastures 13 and 14 where one group receives supplements when the feed is deficient in nutritional qualities.

As a preliminary indication of carrying capacity during the five-year period it was estimated that about 20 to 25 acres per cow, with calf to weaning time, was needed per year, and this rate of stocking resulted in fairly close use of the forage. For moderate utilization 8 or 10 acres more per head was required. Roughly, almost 50 per cent more acreage has been required from August to February than for the remainder of the year. The difference in acreage requirement during these periods is due to various factors, including poor summer feed, and to loss of forage during the summer through trampling.

The six pastures vary considerably in forage productivity as judged by degree of utilization at the end of the grazing period. In one instance this difference in total available forage per animal unit has thus far consistently offset the difference in size of pastures. Pasture 2, which is 230 acres in size, has shown lighter use every season than pasture 4 with 309 acres (table 4 ). The differences between pastures in such things as amount of rock outcrops, swales, inaccessible areas, brush, trees, and soil depth, greatly complicate any attempt to compare the pastures on an acreage basis. In the present stage of the experiments the degree of forage utilization at the close of the annual grazing period affords a more usable basis of comparison, and is the basis here discussed.

The pastures, as well as spots in each, are not all grazed equally close every year, because the total forage crop is not the same from year to year. At the end of the 1937 and 1939 seasons, all the pastures showed closer use than they did in 1938, when only pasture 3 showed comparatively close use-but not so close as during the other two years. At the end of each season the pastures were rated as to whether they showed close, moderate, or light utilization. The three main degrees of utilization pictured in plate 1 were arbitrarily chosen for convenience of the study. In defining and applying them, however, the pastures were critically looked over, permanent plots were staked for comparative and repeated 
examinations, many measurements of stubble height were made, and the visibility or concealment of small ground objects was compared. For example, on closely utilized areas (plate $1, A$ ) the remaining portions of filaree were mainly flat on the ground and less than $1 \frac{1}{2}$ inches of soft chess and foxtail fescue stubbles remain. A very small percentage of soft chess and foxtail fescue plants show no use-approximately 10 per cent where soft chess makes up 35 per cent of the original cover and foxtail fescue 10 per cent. Small objects on the ground the size of golf balls usually show plainly. On areas moderately utilized (plate $1, B$ ) a small

TABLE 4

Estimates of Degree of Utilization Observed at the End of Each Grazing Period in the Six Pastures

\begin{tabular}{|c|c|c|c|c|c|c|}
\hline Year & $\begin{array}{c}\text { Pasture } \\
1 \\
\text { (small) }\end{array}$ & $\begin{array}{c}\text { Pasture } \\
2 \\
\text { (medium) }\end{array}$ & $\begin{array}{c}\text { Pasture } \\
3 \\
\text { (small) }\end{array}$ & $\begin{array}{c}\text { Pasture } \\
4 \\
\text { (large) }\end{array}$ & $\begin{array}{c}\text { Pasture } \\
5 \\
\text { (medium) }\end{array}$ & $\begin{array}{c}\text { Pasture } \\
6 \\
\text { (large) }\end{array}$ \\
\hline 1937. & Close & $\begin{array}{l}\text { Light to } \\
\text { moderate }\end{array}$ & Very close & Moderate & Close & $\begin{array}{c}\text { Moderate } \\
\text { to light }\end{array}$ \\
\hline 1938. . & $\begin{array}{l}\text { Moderate } \\
\text { to close }\end{array}$ & Light & Close & $\begin{array}{l}\text { Moderate } \\
\text { to light }\end{array}$ & $\begin{array}{l}\text { Moderate } \\
\text { to close }\end{array}$ & Light \\
\hline $1939 .$. & $\begin{array}{l}\text { Close to } \\
\text { moderate }\end{array}$ & Light & Very close & $\begin{array}{c}\text { Moderate } \\
\text { to light }\end{array}$ & $\begin{array}{l}\text { Moderate } \\
\text { to close }\end{array}$ & Light \\
\hline
\end{tabular}

amount of filaree, approximately 10 per cent, does not show utilization or trampling. Approximately 50 per cent of soft chess and foxtail fescue are grazed down to nearly $13 / 4$ inches. On areas lightly utilized (plate 1 , $C$ ), approximately 40 per cent of filaree is not utilized or trampled and only about 30 per cent of soft chess and foxtail fescue is grazed at all, and that down to only about $2 \frac{1 / 4}{4}$ inches. Here, objects the size of a croquet ball are often obscured by the remaining vegetation. It will be noted that the height of stubbles on differently grazed areas did not vary so much as the percentage of plants grazed.

Based on such examinations, the pastures were rated as indicated in table 4 . On the basis of average utilization for the three-year period, the pastures may be arranged in three groups : the closest, pasture 3 ; intermediate, pastures 1, 5, and 4; and lightest, pastures 2 and 6 . If the pastures were classified on the basis of four degrees of average utilization, instead of three, the arrangement would be : pasture 3 ; pasture 1 ; pastures 5 and 4 ; and pastures 2 and 6.

The reader is again reminded that the results were obtained on range areas grazed for about a 7-months' period, areas where there was deficient feed for only a short time early in the season and again near the end of the season. Results would probably be different on ranges grazed 
for shorter periods, or on a yearlong basis. Further study will be needed to determine the full effects of varying degrees of use on these ranges stocked for different seasons--and including bad drought years, not yet encountered.

Effect of Different Degrees of Grazing on Early Winter Growth.-The presence or lack of some leftover feed has a marked influence on growth of new forage during the fall and winter. On moderately and lightly used areas, growth is usually 2 or 3 weeks in advance of that on areas closely utilized. This contrast has been consistent during the last four seasons

TABLE 5

Effect on Height Growth of Previous Year's Grazing

\begin{tabular}{|c|c|c|c|}
\hline \multirow{2}{*}{ Species } & \multicolumn{3}{|c|}{$\begin{array}{l}\text { Height of plants (inches) on plots utilized at } \\
\text { different rates in preceding season }\end{array}$} \\
\hline & $\begin{array}{l}\text { Closely } \\
\text { utilized }\end{array}$ & $\begin{array}{l}\text { Moderately } \\
\text { utilized }\end{array}$ & $\begin{array}{l}\text { Lightly } \\
\text { utilized }\end{array}$ \\
\hline \multirow{4}{*}{ 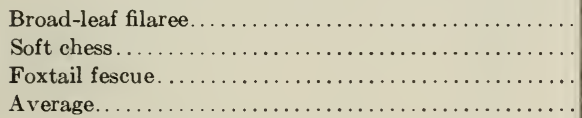 } & 0.30 & 0.57 & 1.18 \\
\hline & 0.92 & 1.46 & 2.14 \\
\hline & 0.79 & 1.19 & 1.69 \\
\hline & 0.67 & 1.07 & 1.67 \\
\hline
\end{tabular}

reported on the Range, both between differently grazed pastures, and between differently grazed spots in any one pasture.

Measurements of height-an important factor in determining availability of forage early in the season-were made on 120 sample plots on December 30, 1938, and on 121 small additional areas on January 27, 1939. These observations are indicative of the effects of old feed on new growth. The December examinations were made near the fence line separating moderately and lightly used areas from closely used ones. In the moderately and lightly used areas height measurements of the broadleaved herbs (all species, but chiefly broad-leaf filaree) averaged 1.0 inch; in the closely used areas they averaged only 0.6 inch. Corresponding measurements for the annual grasses (all species combined) were 2.4 inches and 1.8 inches. The January figures were limited to the three dominant species in closely utilized areas, moderately utilized areas, and lightly utilized areas. The results, summarized in table 5 , show that the height of broad-leaf filaree in the lightly used areas was over $31 / 2$ times higher than it was in those that had been closely used. The leaves were held in the upright position by the old vegetation; in the closely used areas they were almost prostrate on the ground. At this time, broad-leaf filaree in the lightly and the moderately used areas provided considerable feed for cattle, while that on the closely used areas was almost too short to be grazed. Soft chess and foxtail fescue were fully twice as high 
on the lightly utilized areas as on the closely utilized and about one half higher on the moderately used plots.

A moderate amount of feed left on the ground at the end of the season not only offers protection to growth of new feed the next fall and winter but for a time early in the new season it makes up a large part of the animals' diet since it is taken along with the young forage.

When the weather warms in the spring, growth of new feed for a short time becomes very rapid on closely used areas, even faster than where considerable old feed is left. This partly results from the straightening up of broad-leaf filaree. Later in the season, after the weather has become

TABLE 6

Estimated Forage Density from 1935 to 1939 in Pastures of DIFFERENT DEGREES OF UTILIZATION*

\begin{tabular}{c|c|c|c|c}
\hline Year & $\begin{array}{c}\text { Very close } \\
\text { (pasture 3) }\end{array}$ & $\begin{array}{c}\text { Close } \\
\text { (pasture 1) }\end{array}$ & $\begin{array}{c}\text { Intermediate } \\
\text { (pastures 4 } \\
\text { and 5) }\end{array}$ & $\begin{array}{c}\text { Light } \\
\text { (pastures 2 } \\
\text { and 6) }\end{array}$ \\
\hline $1935 \ldots \ldots \ldots \ldots \ldots \ldots \ldots \ldots$ & per cent & per cent & per cent & per cent \\
$1936 \ldots \ldots \ldots \ldots \ldots \ldots \ldots \ldots$ & 35 & 49 & 44 & 44 \\
$1938 \ldots \ldots \ldots \ldots \ldots \ldots \ldots \ldots$ & 31 & 36 & 28 & 36 \\
$1939 \ldots \ldots \ldots \ldots \ldots \ldots \ldots$ & 36 & 44 & 33 & 40 \\
\hline
\end{tabular}

* Exclusive of 1937 when densities were not recorded. Density percentage refers to proportion of the ground area covered by vegetation.

still warmer, height growth in the moderately to lightly used areas again surpasses that in the closely grazed ones.

Effect of Different Degrees of Grazing on Forage Yield, Composition, and Density._-As a result of the different degrees of use over the 7month period each year from 1937 to 1939, certain changes in rangeforage conditions have shown up. Although no pronounced changes due to grazing have been detected in either total forage density (table 6) or species composition, the effect of very close grazing on height growth of forage has been apparent. From measurements made in a series of fenced plots established during the third year of this pasture experiment, the average height of forage in the closest-grazed pasture (no. 3) was approximately 1 inch shorter than in the adjoining lightly used pasture (no. 2).

Slight differences in forage yield were noted in 6 fenced plots placed at random astraddle and at intervals along the fence line separating pastures 2 and 3, in the fall of 1939 before any stock were turned in. Later from each of these plots the vegetation on 40 random samples in open areas was measured, clipped, dried, and weighed. The yield from the plots in the lightly grazed pasture was found to be slightly greater than in the closely grazed one, although the difference was not significant. Comparisons in yield for the pastures as a whole are not yet available. 
It has also been observed that the litter on the most heavily grazed areas is thinning out. More bare soil (less litter-covered) is becoming evident, in comparison with the more lightly grazed areas.

Another interesting comparison of range forage conditions between areas grazed most heavily and others grazed less closely is afforded by the cattle weights-difficult as they are to interpret at this stage of the experiments. Roughly, pounds gain per animal unit decreased as closeness of use increased. For example, the gain per animal unit was smallest on the closest-grazed pasture (no. 3) where "the lower gains and thinner condition of the animals show that the degree of feed utilization was beyond optimum for the well-being of the animals and for maximum net returns." For a more detailed discussion by the animal husbandmen, see the section "Experimental Herd Management," which presents the data showing the effects on the cattle.

Obviously, some undesirable conditions are developing on the heaviestgrazed areas, but whether these trends will continue and what their cumulative effect on the range may be will require a longer period to determine.

Comparison Between Grazed and Protected Areas.-In contrast to the more stable plant associations the annual forage cover, if unused, may change readily and rapidly. The rapidity and extent seem largely dependent on the rate of accumulation of litter on the soil ; hence indirectly on soil productivity. When production is high and litter accumulates rapidly, rapid changes in the cover have been recorded; when production is low the observed changes have been comparatively small in extent and slow in occurrence.

In areas on which old litter has begun to pile up as a result of nonuse the trend of change in composition is toward shade-enduring species of plants. If the litter becomes exceedingly heavy, as it may in only two or three years on highly productive soils under favorable growing conditions, even the most aggressive species may be unable to penetrate it in spots ; consequently both density and yield may be reduced. On the other hand, where the litter accumulates slowly on poor sites, there may be comparatively little change in plant mixtures for several years following protection from range livestock and rodents. These observations on what happens to forage when grazing is excluded have direct bearing on management.

Supporting data are now available from several areas. One is a series of small plots on comparatively shallow soils, fenced against rodents and livestock, established on the Range in 1935. Another is a tract of about 80 acres in the natural area (fig. 1) which has not been grazed by livestock since the station was established in 1934. The third location 
is a set of small supplementary plots established in 1933, 20 miles eastward on the Sierra National Forest, near Northfork, at a higher elevation (2,300 feet) where the plant yield has been greater than on the plots at the Range. The fourth area was a plot in productive soil about 20 miles in the opposite direction at a lower elevation, fenced against livestock for the past ten years.

In the small completely protected plots on the Range broad-leaf filaree increased for one year, then decreased noticeably by the fifth year. Foxtail fescue decreased considerably and was not recorded on the plots in 1939. A marked increase was recorded for soft chess. In general, two species of plants accounted for the most conspicuous changes in cover in these plots in comparison with the grazed pastures during the same period. Slender oat changed but little in the pastures, yet increased several-fold in the tightly fenced plots; and foxtail fescue practically disappeared from these plots but persisted in the pastures without discernible change.

Forage density on these same plots showed no marked change during the period of study. The density in 1935 was 41 per cent; in 1936, 37 per cent; in 1937, 40 per cent; and in 1939, 43 per cent. The average was 40 per cent for the five-year period. These density estimates from year to year are not greatly different from those in the grazed pastures, where the five-year average was 38 per cent.

In the natural area where livestock were excluded but rodents were undisturbed, there was a general decrease in broad-leaf filaree, a noticeable increase in foxtail fescue, and an even larger increase in soft chess.

Changes in forage were more spectacular in the outpost plots, 20 miles away, than on the Range. In these plots the soil was deeper, forage production heavier, and the rodent population lower. Grazing around the plots was heavy in 1934, 1935, and 1936 ; light in 1937 ; and practically nil in 1938 and 1939. Systematic estimates and measurements of vegetation were recorded in 1933, 1935, 1937, 1938, and 1939.

When the protected plots were established at this outpost in 1933, 98 per cent or more of the cover consisted of broad-leaved herbs (table 7), the chief of which were filarees. Two years later, in 1935, a general increase in grasses was recorded for all the plots, but it was much greater on the protected ones. After grazing was lightened on the area grazed by livestock and rodents, grasses continued to increase and by 1939 comprised about 75 per cent of the cover.

Some of the changes indicated in table 7 are of course due to climate; but the replacement of broad-leaved herbs by grasses is significantly greater in the fenced plots. The change was also surprisingly rapid. In the completely protected plot the change from 98 per cent herbs to 96 
per cent grasses occurred in two years-changes far greater and more rapid than those observed on the Range proper, and probably unusual for the forage type as a whole.

The response of this delicately balanced vegetation to extremes of treatment has been further evidenced by the appearance of undisturbed portions of protected plots compared with portions from which the accumulated old dry growth has been carefully removed by hand at the beginning of the growing season. Such comparisons have been made at

TABLE 7

Changes in Percentages of Broad-leaved Herbs and Grasses on Plots Under DifFerent Grazing Treatments at the OUtPost

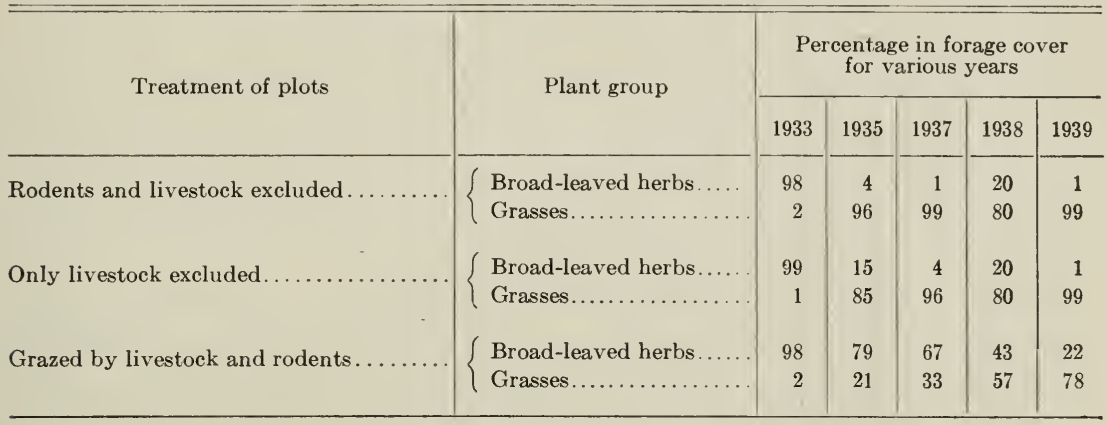

both the Range and at the outpost. The differences in growth on the cleared and uncleared areas were especially marked in the winter of 1939-40. Some of the slender oat was 24 inches high and heading on February 23 on the protected area, while on the cleared area, in contrast, slender oat was lacking and broad-leaf filaree was only slightly over 1 inch in height. This striking contrast was conspicuous for weeks as indicated in plate 2 (upper), which shows conditions in early April.

The plot fenced against livestock for ten years prior to examination in 1938 was in a deep-soiled area where bur-clover, red-stem filaree, and common foxtail are common. Among the observed changes here were the following: Comparatively inferior grasses had increased at the expense of more valuable forage plants-chiefly herbs. Ripgut grass composed 75 per cent of the cover and common foxtail 5 per cent. Soft chess and slender oat together made up 5 per cent. In the outside grazed pasture the grasses, mostly soft chess and foxtail fescue, composed only 50 per cent of the cover ; bur-clover, red-stem and broad-leaf filarees made up most of the remainder. These findings indicate that on low-yielding sites only slight changes in forage composition and density may take place for several years following complete protection from all grazing. On high-yielding areas, however, the litter accumulates rapidly and com- 
paratively tall and inferior grasses may soon crowd out some of the shorter and better herbs. The indications are that on such productive areas the degree of grazing can be used, within broad limits, to keep collective groups of plants in approximately the desired proportions. Thus, not only can annual-type ranges be grazed too closely, but some areas can also be grazed too lightly-at least from the standpoint of maintaining a high percentage of herbs.

The Need for Two Broad Classes of Range Indexes.-In the coöperative studies reported in this bulletin two classes of indexes of range stocking and utilization are employed and are being further developed to aid in understanding: (1) what happens to the grazing animal, and (2) what happens to the range itself-under any given system of management. The first class is dealt with in detail in the following section. Obviously the stockman should utilize fully this simpler and more widely recognized class-livestock, the end product of his business. The second class of index supplies additional information on whether a range "is going uphill, downhill, or holding its own"-basic information for a permanently sustained grazing industry.

Simple plant indicators which reveal general trends of range conditions have been fairly well developed in other western range types, but in the California annual type it is doubtful whether equally simple plant indicators will be discerned. More dependence will likely have to be placed on groups of plants.

A major purpose of the forage-management studies is to build up better range indexes or indicators, more particularly to aid the stockman during bad years when he needs the information most. In good years the need may not be so important. Unfortunately (from an experimental standpoint) the period covered by these studies has not yet included bad drought years; consequently we do not yet know, for example, whether or to what extent a short recuperative period of one or two good years (following drought) may overshadow the effects of several years of grazing at different degrees of closeness.

Even a well-treated range may present vexing problems to the rangelivestock operator in a critical drought year. A range that is running down may seriously intensify these problems. An underlying objective of the studies is to work out techniques both in range handling and livestock handling so that the shock of these critical years may be reduced to a minimum.

Thus the two classes of range indexes (animal and plant) complement each other. Both are important in the appraisal of general range conditions and especially so in this type of range forage because of its big and sudden changes. 


\section{SUMMARY OF THE PRINCIPAI RESULTS OF THE FORAGE STUDIES}

Studies at the San Joaquin Experimental Range show how many of the range-management problems of the foothill section are directly related to the character and behavior of the forage crop.

Range-management practices are built almost entirely around annual plants, which compose about 99 per cent of the herbaceous forage cover on the Range. The sparse perennial grasses have shown no increase during the period of study, even in completely protected places.

Introduced species, mostly from the Old World, account for a surprising portion of the forage cover; they average over 60 per cent.

The herbaceous plant cover consists of some 225 species (190 broadleaved plants, 30 grasses, and 5 grasslike plants), but 10 of these comprise three fourths of the cover, and 2 have made up one half of the livestock forage.

The ratio of broad-leaved plants to grasses was $3: 1$ in 1935 and $1: 1$ for each of the following four years.

Of the broad-leaved plants on the Range, broad-leaf filaree is the most common and important species, and averages 31 per cent of the cover. Since this introduced plant is aggressive, occurs in abundance, and can be depended upon to furnish feed under a wide range of conditions, it is rated as one of the two most important forage species on the area. True clovers, Spanish clover, and popcorn flower are rather sparse but are important range plants at certain seasons of the year. Tarweeds and turkey-mullein are undesirable forage plants but have some value as plant indicators.

Soft chess, another introduced annual, is the second of the two most important forage plants of the area; it averages 19 per cent of the cover. This plant is the most abundant grass and is especially important during the summer. Foxtail fescue, a native annual, ranks second in abundance (13 per cent) among the grasses and third among all of the range plants.

Pine bluegrass, a native plant, is the most common perennial grass on the area, although it makes up less than 0.2 per cent of the cover. Other perennials, still more sparse, are melic and purple needlegrass.

Several native rushes, perennial grasslike plants, are sparse on the Range, yet they composed a considerable part of the diet of the experimental herd of cattle near the end of the green-feed period when most of the other forage had dried.

Several browse species occur on the area but none makes up a very large percentage of the animals' diet. Their greatest importance probably lies in the fact that they provide some green feed during the dry period when the forage crop is deficient in protein and vitamin A. 
Three distinct forage periods underlie the whole problem of foothill range management. The first extends through 4 or 5 months of the summer when feed is mainly dry and low in nutritive values; the second is a period of 3 or 4 months during the fall and winter when green feed starts at the beginning of the rainy season but makes little growth and is generally uncertain or insufficient; and the third period covers 3 to 4 spring months during which rapid growth occurs and the principal forage plants ripen. During the first two periods the forage is usually so poor in either quality or quantity that it does not provide a suitable and dependable ration for cattle.

Most forage plant growth takes place in 4 to 6 weeks during the spring.

Annual-type ranges are exceedingly difficult to stock because the period and rate of growth and the yield of forage vary greatly from year to year. The proportions of the different kinds of plants making up the forage cover also vary considerably, and affect nutritive qualities of the feed and complicate supplemental feeding.

The wide and irregular changes in forage produced from year to year in this annual type necessitate skillful operation on the part of the stockman, in providing supplemental feeds or additional acreage during adverse seasons, and in other ways keeping his business as flexible as possible.

Climatic factors have most to do with yearly fluctuations in forage yield, composition, and season of growth. A seasonal variation in either precipitation or temperature may cause a marked fluctuation in the feed. Rainfall and temperature operate together. The effects of weather on feed appear to be most pronounced early in the growing season and again late in the season; 10 to 12 inches of rain with favorable distribution and temperatures may make a better forage crop than 25 to 30 inches with unfavorable conditions. When more is known about the relation between weather and forage, the operator will be better equipped to deal with the changes and uncertainties of feed that prevail on this range type.

Successful, sustained ranch operation depends upon definite knowledge of what happens when a range is grazed to different degrees and for different periods. The effects of approximately 7 months of heavy, moderate, and light use on this type of foothill range have been studied in a set of 6 pastures-two small ones, two medium-sized, and two large, averaging approximately 155, 240, and 312 acres in size. All have been grazed with approximately the same number of animals, equivalent to about 9,14 , and 18 acres per animal unit in the various-sized pastures. Considerable variation exists between the pastures and they are not 
grazed uniformly; consequently, degree of utilization at the end of the grazing period offers the best basis of comparison.

Three degrees of utilization (close, moderate, and light) have been recognized and described by camera and word pictures. One index of utilization is stubble height; another is the extent to which small ground objects of different sizes are screened or masked by remaining ungrazed vegetation.

These experiments must run for several years before sound conclusions can be reached; nevertheless certain definite trends are apparent from results to date.

Some leftover dry feed means earlier green feed. New green growth has been available from 2 to 3 weeks earlier on areas where some old feed has been left to serve as protection than on areas closely used the previous season.

Under the conditions of this study, forage composition and density were not appreciably affected in three years by the different rates of use for the grazing period of approximately 7 months each year.

Surface soil litter on the most closely used areas has decreased, but the full effect on future composition, density, and yield will require more time to determine.

This annual forage cover under certain conditions may change very readily if completely protected from grazing. On low-yielding sites only slight changes in forage composition and density may take place for several years following complete protection. On high-yielding areas, however, the litter accumulates rapidly and comparatively tall and inferior grasses may soon crowd out some of the shorter and better herbs. The indications are that on such productive areas grazing can be used, within broad limits, to keep collective groups of plants in approximately the desired proportions. Thus, not only can annual-type ranges be grazed too closely, but some areas can also be grazed too lightly - at least from the standpoint of maintaining a high percentage of herbs.

A major purpose of the forage-management studies is to develop better indexes or indicators of range condition, more particularly to aid the stockman during bad years when the information is most needed. Indexes which reveal what is happening to both the animal and the range, under any given method of management are, therefore, important in range appraisal in this annual type. 


\section{EXPERIMENTAL HERD MANAGEMENT}

K. A. Wagnon, H. R. GuIlbert, ANd G. H. HART

The College of Agriculture has for several years studied problems in beef-cattle and sheep production on the range lands that comprise 60 per cent or more of the total area of California. This work has shown the common occurrence of low-percentage calf crops (11) and deficiencies in the range feed with respect to several dietary essentials-notably protein, phosphorus, and vitamin A $(7,12,13)$. It has also been demonstrated that the low value of the dry feed is further reduced by leaching when summer rains occur (9).

There are many important practical problems involved in raising livestock in the area where the Range is located. The green-feed season is relatively short, and a great variation exists in the total dry matter produced per acre from year to year. Some browse is available, although the native species are such that only limited quantities are utilized by the grazing animals. Some ranchers depend upon summer ranges in the mountains under a U. S. Forest Service permit; others obtain fall or winter feed on patented lands in the San Joaquin Valley, and some obtain feed from both types of outside ranges. Still others maintain their herds on home foothill patented land on a year-round basis.

The majority of these cattlemen maintain breeding herds. In favorable seasons veal calves and some grass-fat cows, heifers, and steers are marketed from the area. The difficulty of producing satisfactory slaughter animals for increasingly discriminating markets has necessitated the sale of greater numbers of cattle as feeders.

Many cattlemen in the state are faced with problems of yearlong operation on lower ranges; and since so large a part of their investment is in foothill lands, the objectives in the experimental work reported here placed major emphasis upon long-time investigations bearing on the general problems of yearlong utilization. It was desired to ascertain the kinds and amounts of supplements necessary to correct nutritional deficiencies of the range, and thereby increase efficiency of utilization and promote productive efficiency of the breeding herd and normal economical development of the young animals. Also desirable was a longtime study of the effect of natural environment on the development of animals and on the possible improvement through breeding and selection, comparisons to be made with similar animals receiving supplemental feeds. A further problem was the demonstration by actual trials whether or not it would be economically preferable to turn off finished cattle or to sell offspring as calves, yearlings, or two-year-old feeder steers and 
heifers. One major objective was to ascertain what degree of forage utilization is consistent with the animals' welfare and with maintenance or improvement of the range.

Under agreement with the U. S. Forest Service, the University purchased a foundation herd of cattle to be supervised by a member of the Animal Husbandry staff in residence at the Range:

The foundation females were medium to good, grade Hereford heifers bred to purebred bulls. Originating in New Mexico, they were shipped to Madera County as yearlings. They were free from tuberculosis and bovine infectious abortion and since the Range lands had not been grazed since about July 1, 1934, complications from these two diseases were definitely eliminated. To study the possibilities and limitations of a breeding-up program on an average group of females in such an environment, purebred Hereford bulls were supplied from the University registered herd.

\section{METHODS OF PROCEDURE}

On June 14, 1935, the 70 head of two-year-old, bred heifers were brought to the Range. They were run together and received supplemental feed during their first calving, which occurred during the ensuing fall and winter.

On January 10, 1936, they were divided into two comparable groups, $\mathrm{A}$ and $\mathrm{B}$, of 33 head each, together with their calves. The remaining three animals (one having died) were kept for possible replacement purposes. Group A was to receive supplemental feeds during the late summer and until good green forage was available, while B was to have no supplement except in emergency to prevent death loss. Calf crops from the respective groups would receive the same treatment as their dams. These groups were to remain intact over several years, and replacement was to be made with heifers within the respective groups. The effect of using different sires was minimized by annually alternating the bulls used early in the season when the two groups of cows were separated or by using closely related bulls of comparable quality. Later in the breeding season groups $\mathrm{A}$ and $\mathrm{B}$ were together in the six grazing-intensity pastures described below and were bred to the same bulls.

As female get from the cows reached breeding age, those of satisfactory quality were used for enlarging the herd or for making replacements. Cows were culled for poor type and for barrenness, poor lactation, extreme wildness, and other manifest disabilities.

Concurrently, a series of investigations was designed to obtain data on the effect of three different intensities of grazing upon the cattle and, as described in the preceding section, upon the range vegetation.

Pastures 1 to 6 inclusive (fig. 1) were used in the grazing-intensity 
studies. Pastures 1 and 3 were stocked at the approximate rate of one animal for each 9 acres; pastures 2 and 5, one animal for each 14 acres; pastures 4 and 6 , one animal for each 18 acres. Variations in this general procedure will be discussed as the data are presented. Each pasture contained an equal number of cattle of groups A and B. Unless culled from the herd, the same animals were returned to the same pasture each year. The entering date was the time when the new green feed was considered abundant enough to carry cows suckling calves satisfactorily without supplement. For the years reported in this publication, this time came in January or February. The animals remained in these pastures until August or September. The criterion for removing the cattle consisted in evidence that the feed in the smallest pair of pastures had been closely utilized. Upon removal, the cattle were segregated into their respective groups and placed in separate holding pastures until the next green-feed season. Pastures 11 and 12, until 13 and 14 became available in 1938, were used mainly as fall holding pastures for the cow herds. The other enclosed fields shown in figure 1 were used to pasture weaner calves, yearlings, and other stock.

Supplemental feeding began, for calves, at weaning time; for other group-A animals, when the cattle were removed from the six grazingintensity pastures. The amounts and kinds of supplements used varied with the amount and character of the range forage and with the condition and needs of the cattle. Cottonseed cake (43 per cent protein) and rolled barley were the principal feeds used. In general, when dry feed was plentiful, the amount of cottonseed cake necessary to correct protein deficiency (1-2 pounds daily) sufficed to promote gains and efficient utilization of the forage. After the first rains and when green feed was scant, additional barley was used whenever it was a cheaper source of the extra total nutrients needed for maintaining milk flow or for preventing weight loss in young animals. The maximum supplement, usually 3 pounds daily, had to be increased to 5 pounds under the extreme conditions of 1937-38 winter period. Unless otherwise stated, supplemental feeding was done daily in the morning. The feed was placed in troughs, and the cattle were trained to come to their feed by calling them.

The original females dropped their first calves mostly from October to January, a time somewhat earlier than is the practice in the area. It was desired, however, to investigate the practicability of early calving in connection with the supplement-feeding program. Placing the bulls with both groups at the same time was necessary because they were pastured together during most of the breeding season. The bulls were placed with the cows about December 28 and were removed early the following May.

Either coarse-ground or block salt was available for the cattle at all 
times. Observations were made on the relation of its accessibility to the movements of cattle on pastures.

Water on these pastures was developed to a greater extent than on many California ranges and, being more accessible in relation to the feed supply, resulted in better average utilization of the feed over the entire area than is frequently the case.

The main corrals and scales shown in figure 1 were built at the start of the experiments. In 1939, a second set was established on the division fence between pastures 13 and 14. The experimental animals became gentle and were handled through the corrals and scales with care, so that shrinkage in handling was reduced to a minimum.

Weights were taken when there were major changes in the method of procedure such as moving into the six grazing-intensity pastures at the beginning of the year, the end of the green-forage period, weaning time, starting of the supplement-feeding period, and just before calving. Weaner calves were weighed monthly during the first period that they were fed supplements. All weights presented in this publication were taken on a "full" basis; the animals were driven in from pasture and allowed to drink before weighing.

The animals were individually identified numerically by tattooing the ears, and by branding with caustic fluid for field identification. Individual records were kept. Over the period covered by this report, one of the authors collected forage samples by hand, following the cattle closely to take samples of the forage as grazed. He also observed the grazing habits and movements of the animals.

\section{EXPERIMENTAL DATA}

During the period when the data here presented were being collected, calendar years 1935 to 1940, both seasonal rainfall and temperature produced favorable growth of feed, which consisted almost entirely of annual species that would cause these years to be classed as reasonably good. Before the experiments were started, forage samples were being collected from this locality for part of the data published by Hart, Guilbert, and Goss (13). During that period there were much less favorable feed years, and forage was considerably less abundant. Nevertheless, during the time covered by the data in the present publication twice as much feed was produced in some years as others. Since feed conditions varied so greatly from year to year and since the data on different age groups are so limited, in most cases no attempt has been made to present average results for the entire period. Data covering additional years of work must be secured before definite conclusions can be drawn.

In table 8 and in subsequent paragraphs, the times when the breeding 
herds were confined to the six grazing-intensity pastures are designated as the "grazing periods." The times when the A and B herds were separated in the fall and winter pastures and when group A received supplemental feeds are designated as "supplement periods."

The principal data obtained from the breeding herds for 1935-1940 are presented in table 8.

Weight Variations of Breeding Cows.-The average weight of the 70 foundation heifers when delivered on the Range, June 14, 1935, was 794 pounds. Although there was a plentiful supply of forage, the animals

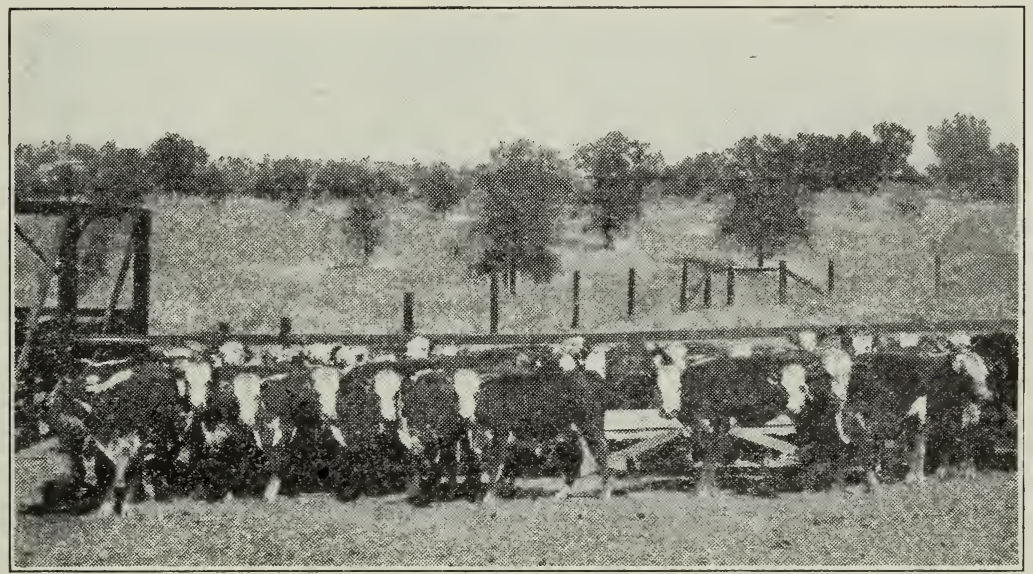

Fig. 10.-Foundation heifers as they appeared September 24, 1935, at the beginning of their first calving period.

just maintained weight up to September 24. They had advanced in pregnancy during this time and had actually lost considerable flesh. They were moved to another pasture of ungrazed dry forage, and supplemental feeding started. The appearance of the heifers at this time is shown in figure 10. Ninety-four per cent of these heifers calved between September 9, 1935 and January 10, 1936. Milk supply on dry feed with supplements was satisfactory for first-calf heifers, green feed developed early, and most of the weight loss at calving had been regained by the end of the period. Table 8 shows the subsequent pasture gains for the grazing period January 10 to August 4, 1936, for the cattle now divided into two permanent groups.

During the feeding period beginning August 4, 1936, until second calving, animals of group A (fed supplements) gained on dry forage and 1 to 2 pounds of cottonseed cake, while group B lost weight. After calving, group A received up to 3 pounds of supplements daily. They had good udder development and the calves were thrifty. The animals of 
group B, though given twice as much acreage for grazing, were conspicuously lacking in udder development after calving on dry feed; and the calves looked rather "dry-haired." Green forage again came on early, however, evidently before stimulus for milk production was lost, since weaning weights of the calves from the two groups did not differ significantly when ages and sex were considered. Though there was an 81pound average weight loss in group B and although the animals were thin, they were in strong condition at the end of the period. A snowstorm followed by cold weather occurred after the beginning of the subsequent grazing period (January 2 to August 10, 1937). The forage regressed and the cattle lost weight during the first 2 months. During the 1937 grazing period, animals of group B gained more than group A, because those of the latter were in better condition at the beginning of the period.

During the early part of the supplement period August 10, 1937 to February 25, 1938, group A animals again made some gain on dry forage plus cottonseed cake. Dry feed became scarce in December, and cold weather prevented significant growth of new forage until February. During this time double quantities were fed every other day. The amount was increased to 8 pounds every other day during part of the period to prevent excessive losses in weight and to maintain milk flow. Despite this liberal feeding, the animals were 158 pounds lighter at the end of the period than before calving. The inclusion of two-year-old, unbred heifers in the averages shown in table 8 somewhat obscures the results with cows that calved. The loss in weight of group $A$ cows that calved was 239 pounds; that suffered by the corresponding group B cows was 331 pounds.

Group A carried some reserve flesh at the beginning of the period and remained strong; the calves did well. Group B animals became extremely thin and weak. Two calves starved because their dams failed to lactate, and one cow died of exposure and of the infection resulting from a retained placenta. To prevent serious death loss, supplemental feeding was started. Three more cows died subsequently as a result of the impoverishment. The others soon showed marked improvement. They then traveled to outlying portions of the pasture for forage, whereas they had previously stayed close to water and salt, and thus accentuated the effect of feed shortage by limiting their grazing area. The calves from group B appeared unthrifty. Many of their mothers were "dry" or nearly so before good forage was available.

The gains of the cows were large during the next grazing season (February 25 to September 2,1938 ) after these heavy losses. Again group B animals gained more during the grazing period.

Eight two-year-old, unbred heifers were added to each group at the 
beginning of the supplement period of September 2, 1938, to January 25, 1939. Pastures 13 and 14 became available and were used for the first time for groups A and B respectively. Although the acreage per cow was somewhat greater for group A, there was no conspicious difference in the amount of total forage available for the two groups. Because of the short time that remained before calving, supplement-feeding with group A was started at the rate of 4 pounds every other day. After rains in late October the amount was increased to 6 pounds on alternate days and later decreased as the forage improved. Table 8 shows the total supplements fed. The average weight losses of the groups (as shown in the table) again obscure results on the cows that produced calves, not only because two-year-old heifers were included but also because there were more dry cows in group B. The weight loss of cows calving in group A and group B averaged 155 and 268 pounds respectively. In general, group B cows and heifers were thin, especially those that had also calved the previous year. The calves from these animals showed effects of lack of milk compared with those of the group fed supplements.

In the grazing season, January 25 to August 1, 1939, there was, on account of low rainfall, an absence of late-growing green feed in the swales. Maximum weight was attained in May, when all feed dried and the cattle lost weight until removed from the grazing-intensity pastures. Net gains for the period, therefore, were less than in previous years.

At the beginning of the supplement period, August 1, 1939, to February 8, 1940, group A received daily 1 pound of cottonseed cake. Rains started forage growth in September. Lack of rain thereafter resulted in regression of the forage in December. In the interim, while forage was good, group A refused supplements. Table 8 shows the total supplements fed. There was over 100 pounds' difference in the average weight of the two groups of cows at the end of the period, though five less animals in group B had calves.

Death Losses and Retained Placentas.-Table 8 shows a loss of two cows in group A and six cows in group B, during the entire five-year period; one animal had died before the groups were originally divided. The deaths in group A resulted from eversion of the uterus at calving. All the losses in group B were caused by impoverishment, with or without complications from retained placentas and subsequent infection.

As table 8 shows, there were 37 retained placentas in group B, and 11 in group A. Some of these cows received treatment; others did not. Treatment doubtless saved additional death losses in the thin group B animals. The effects of these complications on subsequent pregnancies was not serious, for little or no permanent sterility resulted. Only during 
the 1939 calving season did similar numbers of cases occur in each group. In that year green feed started early; group A refused supplements for a time and then forage became poor. Forage on north slopes in pasture 14 suffered less from drought than that on the south exposures of pasture 13, and the animals not fed supplements had more favorable feed conditions than usual.

Calf Crops and Weaning Weights.-As previously stated, 94 per cent of the original heifers dropped calves the first year. Seven of these offspring were lost shortly after birth, four being killed by coyotes.

Because these cattle calved earlier than is customary in this area, there was an accumulation of coyotes upon the range. Although actual attack or slaughter of a calf by a coyote was not observed, K. A. Wagnon counted twelve separate coyotes in the fields containing the cattle one afternoon and observed a coyote chasing a calf. In all cases the calves attacked were isolated animals hidden by their dams away from the group. The Biological Survey, having been requested to hunt the Range, trapped 35 coyotes in 30 days. No dogs or other marauders were seen by the trapper or the Range personnel. Since this time coyotes have been hunted annually during the calving period and no more calves have been lost from this cause. The percentage calf crop weaned (table 8) was 84.3 per cent.

The 1937 calf crop represented the second calves from the original heifers. Both groups were being treated alike at the time of breeding, and no significant difference in the calf crop is shown. The third crop of calves (dropped between October 3, 1937, and January, 1938) was the first in which variations in reproduction resulting from the difference in feeding management of the two herds could be expected.

Twenty-seven calves were dropped in group A; 25, in B. Four calves (one premature, one still-born, and two whose mothers died from eversion of uterus) were lost in group A. Five were lost in B from causes directly attributable to undernutrition. The difference in percentage calf crop weaned is shown in table 8, which also reveals nearly 100 pounds' difference in the weaning weights of the two groups.

The fourth calf crop (dropped mostly between September 25, 1938, and January 1, 1939) included calves from first-calf heifers that had been added to the herd as well as from the mature cows. A still birth from a group B heifer was the only calf lost this season. The difference in percentage calf crop between the two groups is, therefore, due mainly to the number of dry cows. There was little difference in percentage calf crop from the heifers of the two groups. Calf crop from group A cows was 91 per cent in contrast to 61 per cent for group B, the cows of which were very thin the previous winter. Besides the difference in percentage 
calf crop, there was also a significant difference in weaning weight of the calves from the two groups. This difference was greater between the calves from heifers than from the mature cows of the two groups.

The fifth calf crop was dropped between September 26, 1939, and January 23, 1940. The percentage calf crop born was 94 per cent in group A, 73 per cent in group B. These subdivide by age groups as follows: the percentage from group A cows was 100 per cent and from group B, 77 per cent; from second-calf heifers of group A, 78 per cent and from group B, 58 per cent. For the years 1938, 1939, and 1940 the percentage calf crop and weaning weight difference between the two groups is largely attributable to the supplements fed group A cows. The total pounds of calf production at weaning time per breeding cow for the two groups was as follows :

\begin{tabular}{|c|c|c|}
\hline $\begin{array}{l}\text { Year } \\
1938 \ldots \ldots \ldots \ldots \ldots \ldots . \ldots 335\end{array}$ & $\begin{array}{l}\text { Group B } \\
234\end{array}$ & $\begin{array}{l}\text { Difference } \\
\quad 101\end{array}$ \\
\hline $1939 \ldots \ldots \ldots \ldots \ldots \ldots 432$ & 294 & 138 \\
\hline $1940 \ldots \ldots \ldots \ldots \ldots \ldots 424$ & 333 & 91 \\
\hline
\end{tabular}

If supplement-feed cost is computed at 1.5 cents per pound and the value of all calves at 8 cents per pound, the added income over feed cost for group A varied from $\$ 3.03$ to $\$ 6.36$ per head. In addition to this difference in pounds of production per breeding cow under the two systems of management, the margin is further widened by the fact that the calves from group A have been appraised each year at about 50 cents per hundredweight higher than those of group B.

During all the periods covered, the calf crop was influenced by five abortions, four of which were in group A. Three of these cows, when tested, proved negative to the Brucella abortus agglutination test. One cow aborted after severe illness, the cause of which was not ascertained. None of these cases could be attributed to $B$. abortus infection or to vitamin-A deficiency.

Weaner Calves.-Each year the calves have been weaned about July 1. The two calf groups A and B, were separated and held in corrals until weaned. Both groups were fed concentrates in addition to hay during the few days at weaning time in order to get them started on supplements and so that the group B animals might more readily take supplements should emergency arise later. After weaning, the groups were placed in separate pastures, usually a combination of pastures 7, 8, 9, and 10 . Separate weight records were kept on steers and heifers. Supplemental feeding was continued with group A. Table 9 gives the data for the 1935 , 1936,1937 , and 1938 calf crops.

The 1935 calf crop (designated as groups A5 and B5 to indicate year of birth) was from mothers that had received similar treatment and was 


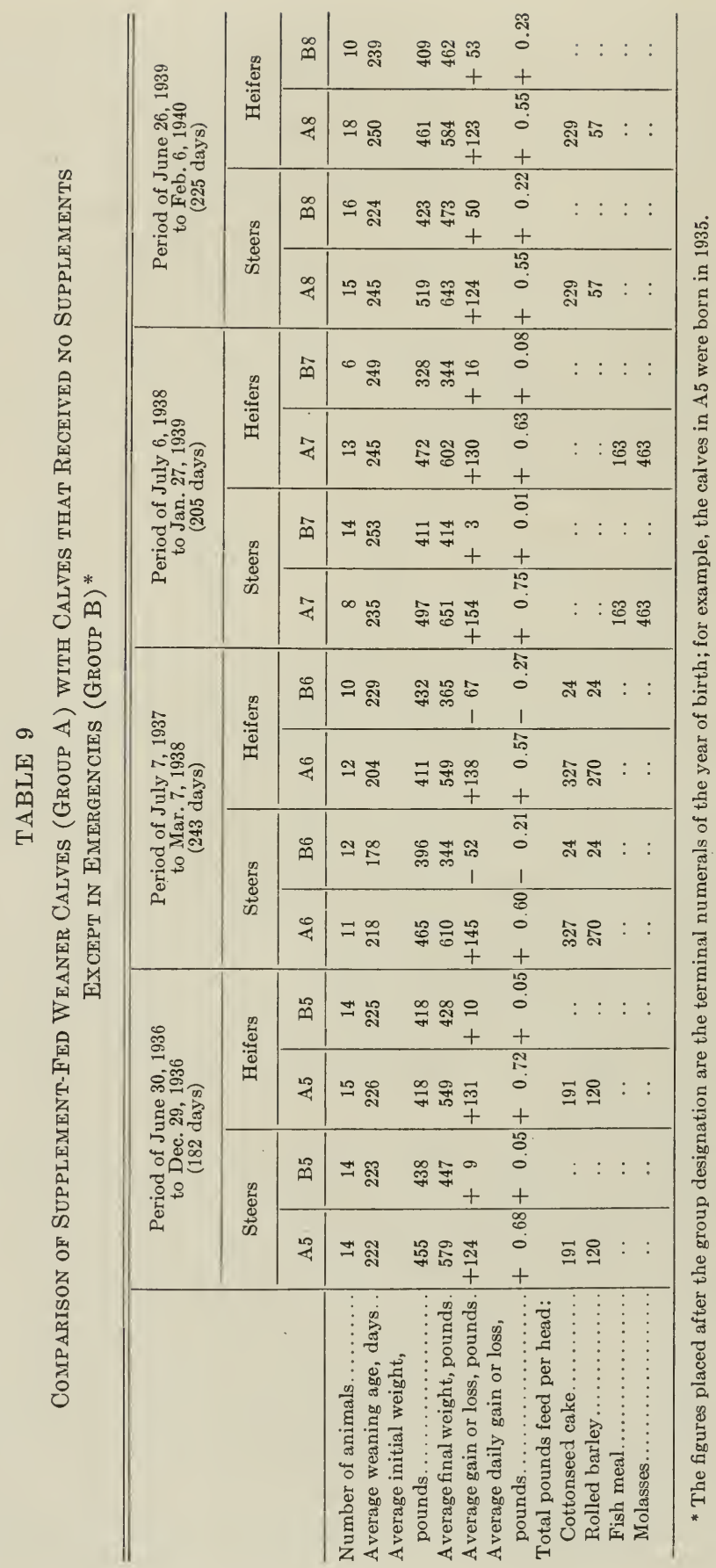


equally divided as to weight and quality. Death loss of a light calf in group A5 and a heavy calf in B5 subsequently unbalanced the average initial weights of the two groups of steers. Group A5 was fed 1 pound of pea-sized cottonseed cake for 110 days. After the first autumn rains 2 pounds of rolled barley daily were added to maintain gains till the end of the period. Except for the month after the first fall rains, group A5 made continuous gains. Group B5 gained during the first month on dry feed, lost weight for 3 subsequent months, then gained on new green forage, but at the end of the period was only slightly heavier than at weaning time 6 months before.

As previously discussed under the breeding herd, the difference in weaning weights of groups A6 and B6 (1936 calf crop) is not significant when age and sex variations are considered. One to 1.5 pounds daily of cottonseed cake was fed to group A6 for 2 months, and then 1.5 pounds barley was added for about 2 months. Continued cold weather after the first of the year prevented forage growth until March. Range feed became very scarce, and 5 pounds daily of supplements during part of the period were required to prevent weight losses. Severe weight loss occurred in group B6; the animals became thin and weak towards the end of the period and received supplemental feeding for 48 days, to prevent death losses. Group A6 was in thrifty condition at the end of the period. Figure 11 shows these two groups as they appeared in December, 1937.

There was a very significant difference in the weaning weights of groups A7 and B7 of the 1937 calf crop, as was previously explained.

The possibility of self-feeding of fish meal on the range, and also of self-feeding a mixture of fish meal and molasses, was investigated with group A7. The calves readily ate fish meal alone at weaning time. When they were self-fed in the pastures, the quantity taken was too great to be economical. Fish meal was then self-fed mixed with molasses. Consumption of the mixture increased to about 9.5 pounds daily; dry range feed utilization was poor, bloating occurred, and gains were not commensurate with cost. The hand-feeding of restricted amounts was therefore necessary. The gains and condition of this group over the entire period were reasonably satisfactory, whereas the group not fed supplements only maintained their weight over the $61 / 2$ months' period and were in thin condition. Because of the difference in forage and weather conditions from year to year, direct comparison of the feeding value of fish meal and molasses with cottonseed cake and barley is not justified.

The difference in average weight of the two groups by the end of the period was further increased to 250 pounds.

The 1938 calf crop again showed a significant difference in weaning weights of the calves from the breeding herds that were fed supplements 
contrasted with those that were not. The feeding procedure for group A8 resembled that for the 1935 and 1936 calf crops. Feed and weather conditions were favorable and, as table 9 shows, there was less difference than usual in gains between the two groups during the period.

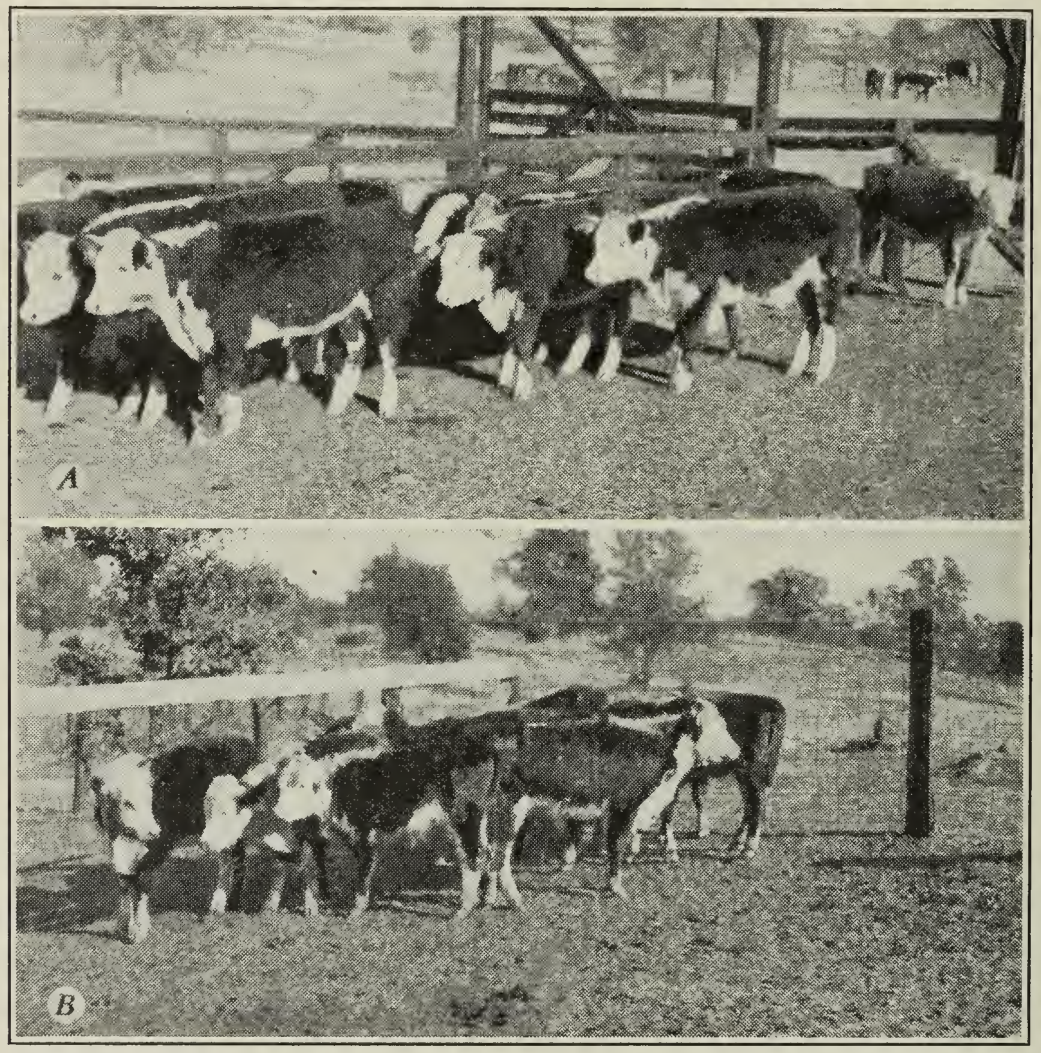

Fig. 11.-In $A$ are shown the animals of group A6 (fed supplements) as they appeared on December 6, 1937. Those of the corresponding group B6 (not fed supplements) are shown in the lower picture, $B$.

Pasture Gains After the Weaner-Calf Period.-Since most cattle are sold at the end of the forage season rather than at the end of the wintering period, the net value of supplemental feeding of calves is best judged by the weight advantage existing at the end of the next grazing period. Table 10 gives the data for the various groups.

In all cases, group B animals that had lost or only maintained weight from weaning through their first winter, gained somewhat more the next pasture season than group A animals which had made continuous growth. There was, nevertheless a variable but significant difference be- 


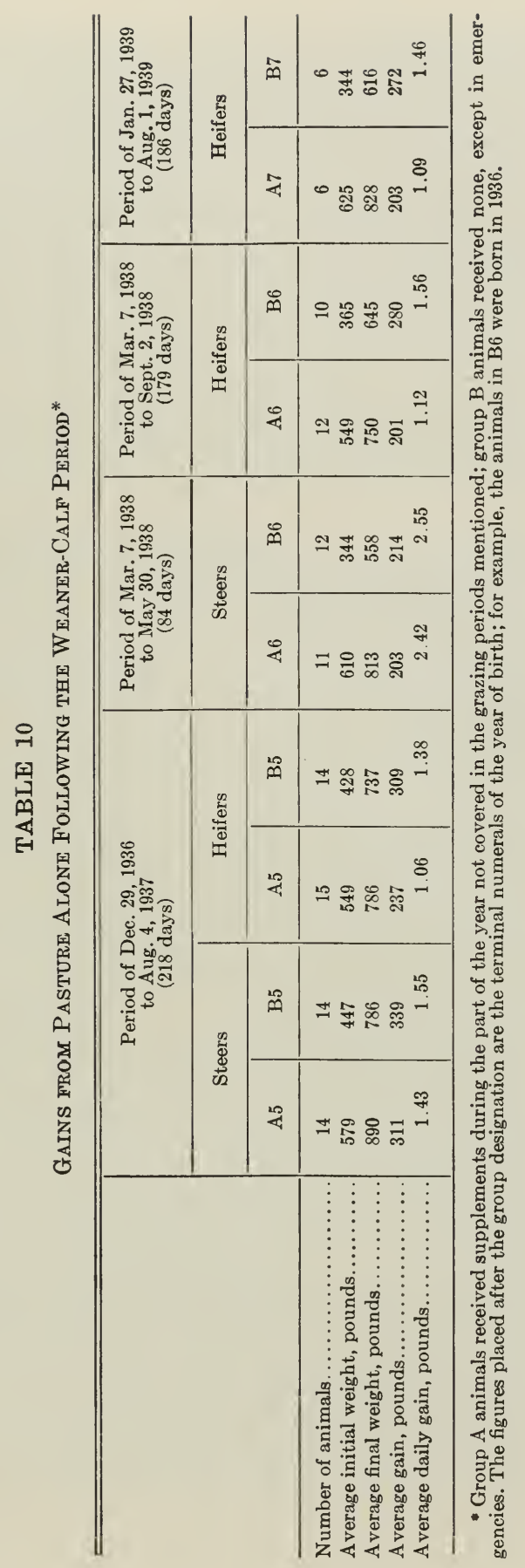


tween the final weights of comparable groups each year. Data are given for only 84 days for groups $\mathrm{A} 6$ and $\mathrm{B} 6$ steers because the former were placed on a finishing ration after this time. Aside from the higher gains of both groups for the short period, pasture gains varied from 1 to 1.5 pounds daily.

The possibility of marketing 450 - to 500 -pound weaner calves or 800 to 900 -pound yearling feeders through supplemental feeding of weaner calves is indicated. These animals, by reason of greater weight and condition, were suitable for finishing in a short time in the feed lot and

TABLE 11

Summary of Feed and Weight Records on Replacement Heifers from Weaning until Start of First Calving Period*

\begin{tabular}{|c|c|c|c|c|}
\hline & $\begin{array}{c}\text { Group } \\
\text { A5 }\end{array}$ & $\begin{array}{c}\text { Group } \\
\text { B5 }\end{array}$ & $\begin{array}{c}\text { Group } \\
\text { A6 }\end{array}$ & $\underset{\text { B6 }}{\text { Group }}$ \\
\hline Number of animals. & 15 & 14 & 10 & 8 \\
\hline Average weaning weight, pounds.. & 418 & 418 & 425 & 437 \\
\hline Final weight, first supplement period, pounds... & 549 & 428 & 573 & 370 \\
\hline Supplements per head, pounds .............. & 311 & & 597 & 48 \\
\hline Final weight, first grazing period, pounds... & 786 & 737 & 765 & 651 \\
\hline Final weight, second supplement period, pounds... & 723 & 579 & 790 & 606 \\
\hline Total supplements per head, pounds........... & 462 & 125 & 312 & $\ldots$ \\
\hline Final weight, second grazing period, pounds. . & 1,007 & 950 & 953 & 824 \\
\hline Total supplements fed to first calving period, pounds... & 773 & 125 & 909 & 48 \\
\hline
\end{tabular}

* Group A animals received supplements during that part of the year not covered by the grazing periods; group B animals received none, except in emergencies. The figures placed after the group designation are the terminal numerals of the year of birth; for example, the animals in B5 were born in 1935.

would, therefore, ordinarily bring a higher price for this purpose than the lighter, thinner cattle that received no supplements.

Data on Replacement Heifers.-Table 11 presents data on heifers used for additions or replacements in the breeding herd, and covers the time from weaning until the beginning of the period during which they first calved. As previously mentioned, there was no significant difference between groups in percentage calf crop at first calving. Group A5, however, had calves averaging 86 pounds heavier at weaning time and the following year produced a 78 per cent calf crop as compared with 58 per cent for group B5.

Since this work was started, practically all the heifers have been used for enlarging the breeding herd or for replacement, as shown in table 12.

During the first four years there was a total of 98 heifers exclusive of death losses. Of these all but 25 were added to the breeding herd. Because of difference in calf crop and chance variations in sex ratio there was more opportunity to select the most desirable replacements from group A than from B heifers. Seventeen group A heifers were finished for slaughter as long-yearlings. Two group A and six group B heifers 

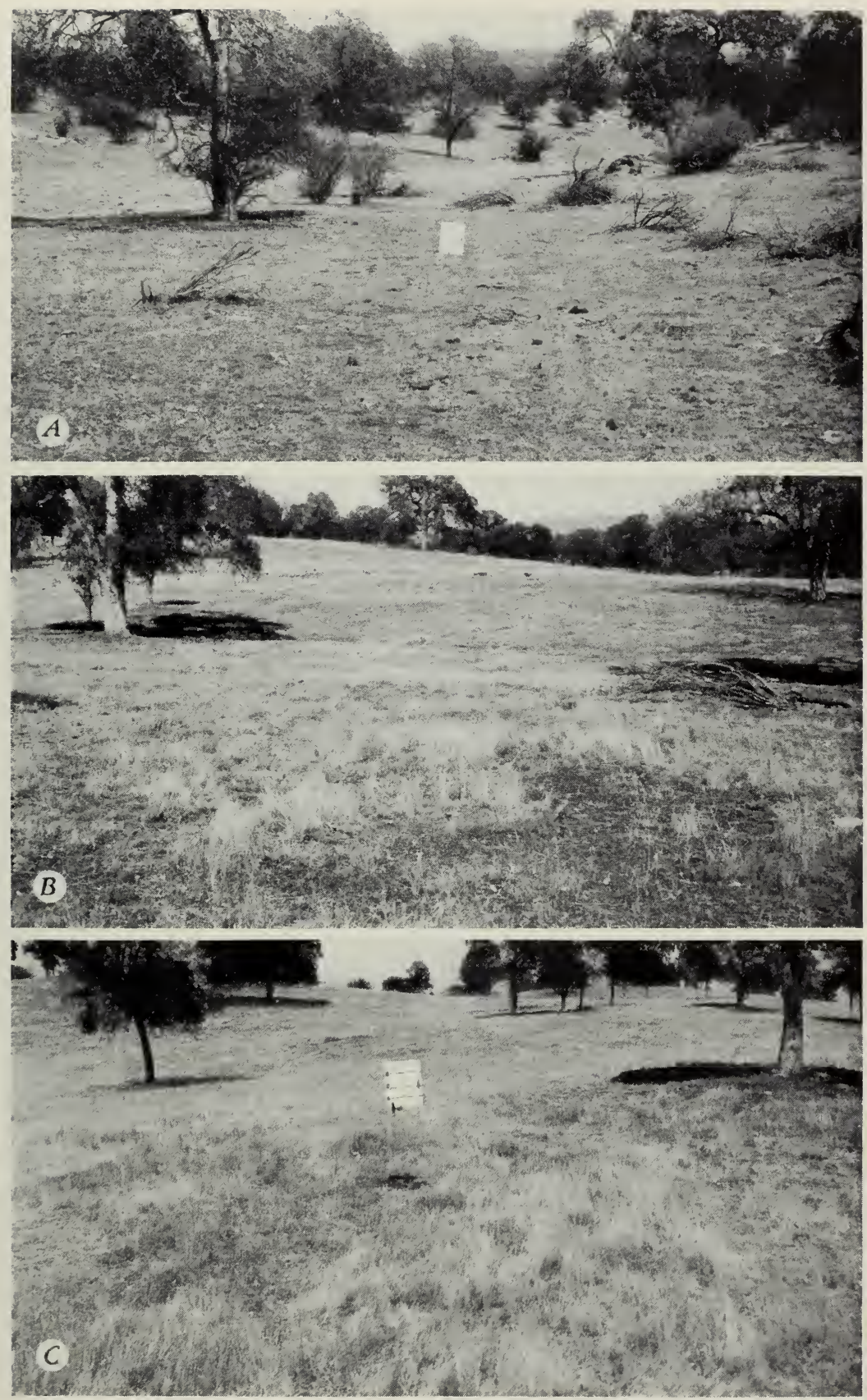

Plate 1.-Areas showing close $(A)$, moderate $(B)$, and light $(C)$, utilization in August at the end of the seven months' grazing season. 

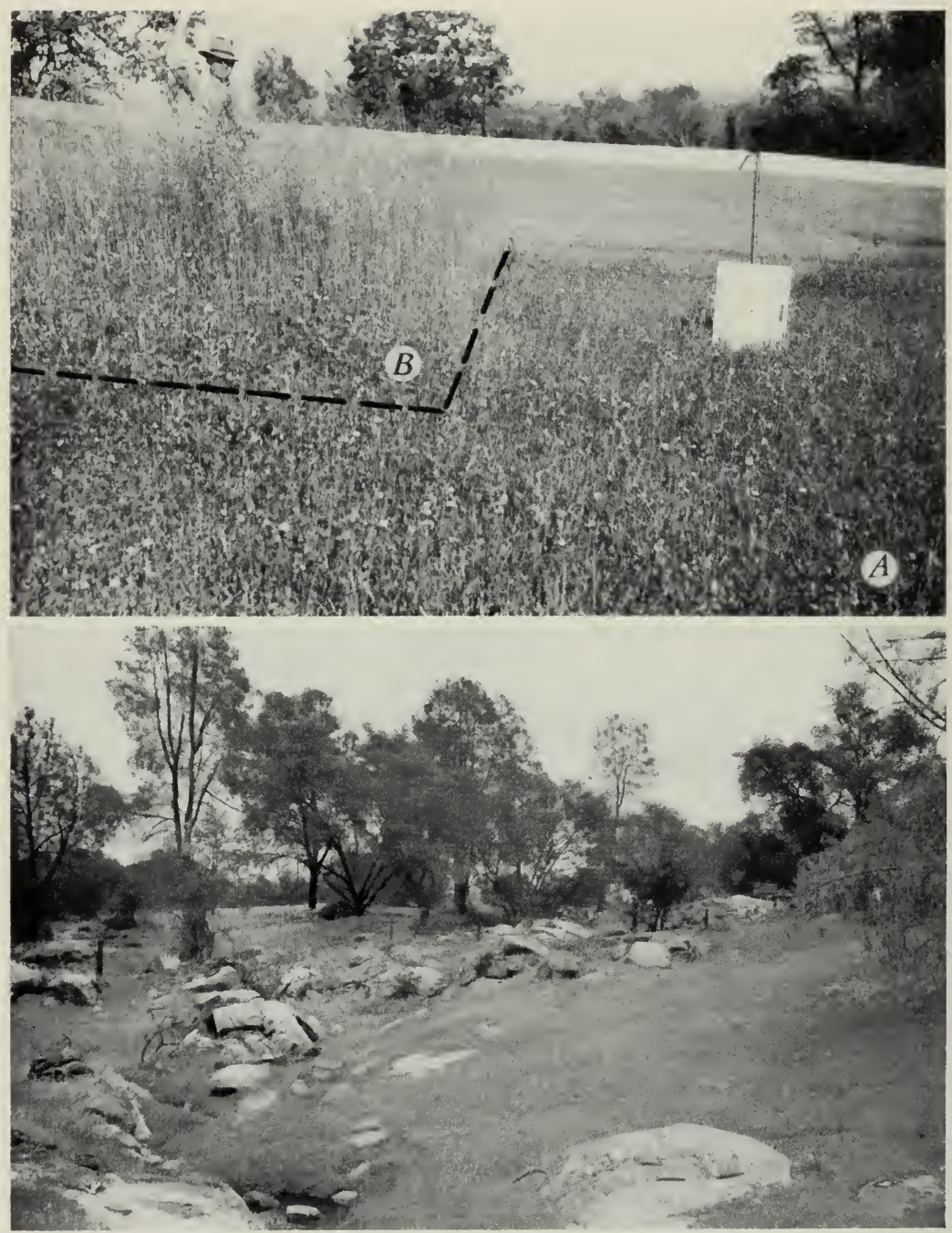

Plate 2.-Upper: Differences in height of vegetation in areas cleared of old growth at the beginning of the growing season, compared with undisturbed areas. Both these areas were ungrazed by either rodents or livestock. A, Cleared part of plot; $B$, uncleared. Lower: Typical range inhabited by kangaroo rats, ground squirrels, pocket gophers, rattlesnakes, and cottontail rabbits. 
were sold as feeders. When this manuscript was written, the 1939 heifer calves were still too young for a decision regarding them to have been made.

Management and Disposal of Produce.-Because of the demand for information on finishing cattle, both as yearlings and as two-year-olds, the original plan of disposing of surplus as yearling feeders was temporarily abandoned.

The data for group A5, table 13, include periods on pasture alone during 1937 and 1938, a period of supplement-feeding in the fall and

TABLE 12

Heifer Groups as Used for Enlarging the Breeding Herd and FOR REPI.ACEMENTS

\begin{tabular}{c|c|c|c|c|c|c|c}
\hline \hline Year & $\begin{array}{c}\text { Group A } \\
\text { heifers }\end{array}$ & $\begin{array}{c}\text { Group B } \\
\text { heifers }\end{array}$ & $\begin{array}{c}\text { Total } \\
\text { groups } \\
\text { A and B }\end{array}$ & $\begin{array}{c}\text { Replace- } \\
\text { ments } \\
\text { in group A }\end{array}$ & $\begin{array}{c}\text { Replace- } \\
\text { ments } \\
\text { in group B }\end{array}$ & $\begin{array}{c}\text { Disposal } \\
\text { of } \\
\text { group A }\end{array}$ & $\begin{array}{c}\text { Disposal } \\
\text { of } \\
\text { group B }\end{array}$ \\
\hline $1935 \ldots \ldots \ldots \ldots$ & 15 & 14 & 29 & 15 & 14 & $\ldots$ & $\ldots$ \\
$1936 \ldots \ldots \ldots \ldots$ & 12 & 10 & 22 & 10 & 8 & 2 & 2 \\
$1937 \ldots \ldots \ldots \ldots$ & 13 & 6 & 19 & 6 & 4 & 7 & 2 \\
$1938 \ldots \ldots \ldots \ldots$ & 18 & 10 & 28 & 8 & 8 & 10 & 2 \\
\hline
\end{tabular}

winter of 1937-38, and a short finishing period. Their check group (B5) received no supplements throughout life. Group A5 gained only 47 pounds during a 215-day period of supplement feeding. Feed shortage during this period not only prevented good gains but also necessitated heavy supplemental feeding during part of the time to prevent weight loss. The corresponding group (B5) lost nearly 200 pounds during this period. The carcass weights for group A5 were somewhat heavy for general demand, but graded Good. The carcasses of group B5, on the other hand, had practically no fat covering and graded Medium and Common. These animals, though unsuitable for slaughter, would have been desirable feeders. The appearance of the two groups one month before marketing is shown in figure 12.

Group A6 indicates possibilities of producing satisfactory slaughter cattle as long-yearlings through promoting continuous gains as weaners followed by a short finishing period at the end of the green-feed seasoll. Ten carcasses graded Good, and one, Top Medium; the yield was 57 per cent. Their weights may be compared with their control group (B6), sold as feeders a year later. Size and condition of average steers from each group are compared in figure 13.

Group A7 steers and heifers not only were fed supplements during the period from weaning to the next grass season but also had the feeding of fish meal and molasses continued during the green-forage season and 


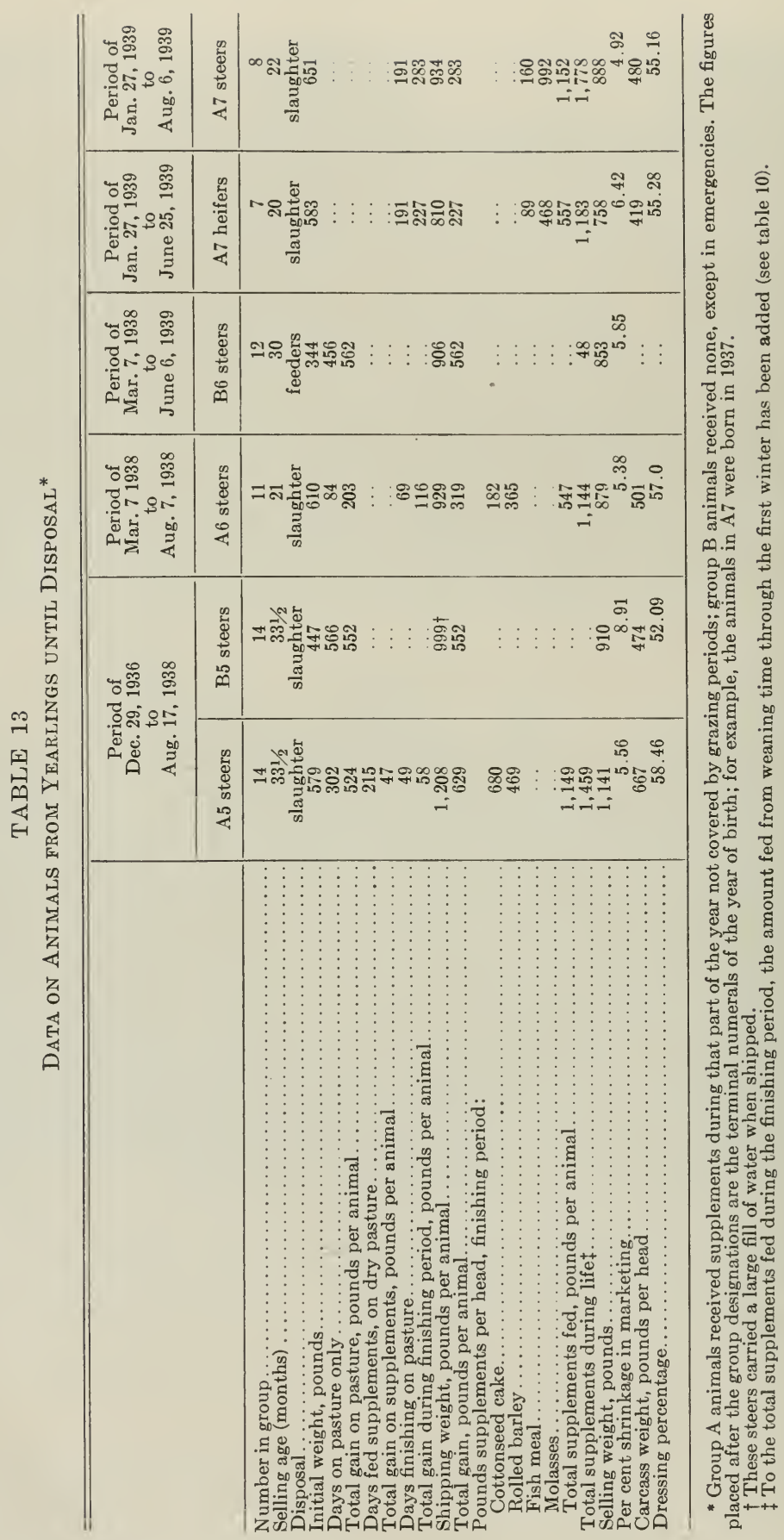


until they were marketed. Their carcass yield indicates less finish than was obtained by group A6, marketed the previous year. Group B7 was held over for sale as two-year-old feeders the following year.

Grazing-Intensity Pastures.-Data on the animals grazing pastures 1 to 6 inclusive were collected in relation to the study of the effect of

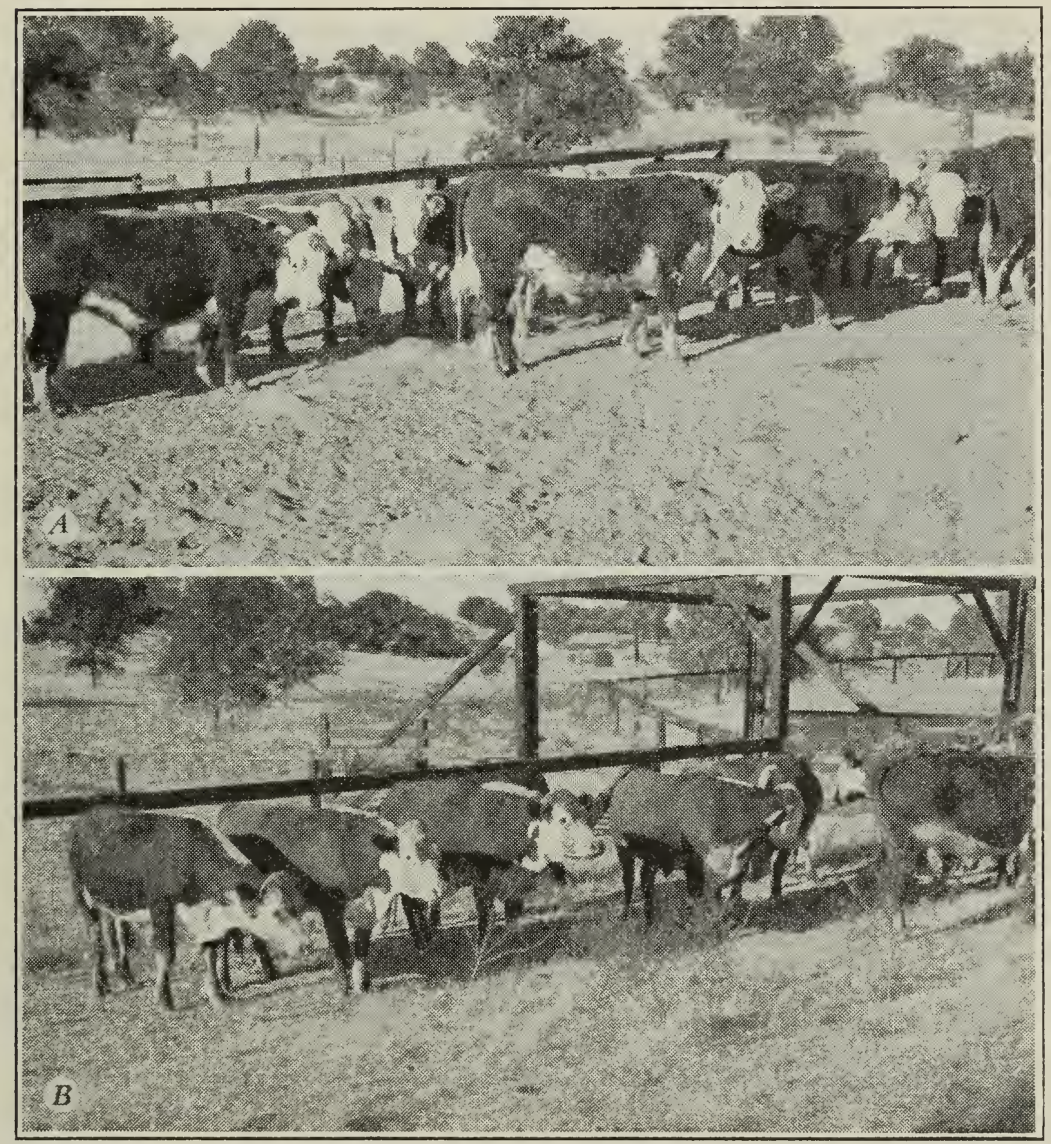

Fig. 12.-Two-year-old steers on July 17, 1938, one month before they were marketed. Those of group A5 are shown in $A$; those of group B5, in $B$.

stocking on the forage in these pastures. Several factors complicate interpretation of the record. The period covered is short, pastures comparable in size were not comparable in forage production, and the animals were not on the area the year-round. The equal division of group A and B animals in each pasture made small groups of each. This diffculty, together with variation in the number of replacement heifers and possibly other factors, thus far obscures any difference in calf crop that 
might be attributed to feed supply during the period reported. For example, culling of wild cows and those that aborted contributed to heavier replacements in pasture 3 , though the thinner condition of these animals may in some cases have inadvertently also influenced culling.

Table 14 presents average data for the four-year period 1936 to 1939 inclusive.

For this 6- to 7-months' period the difference in net gain per animal unit between pastures 1 and 3 is greater than between pasture 1 and any

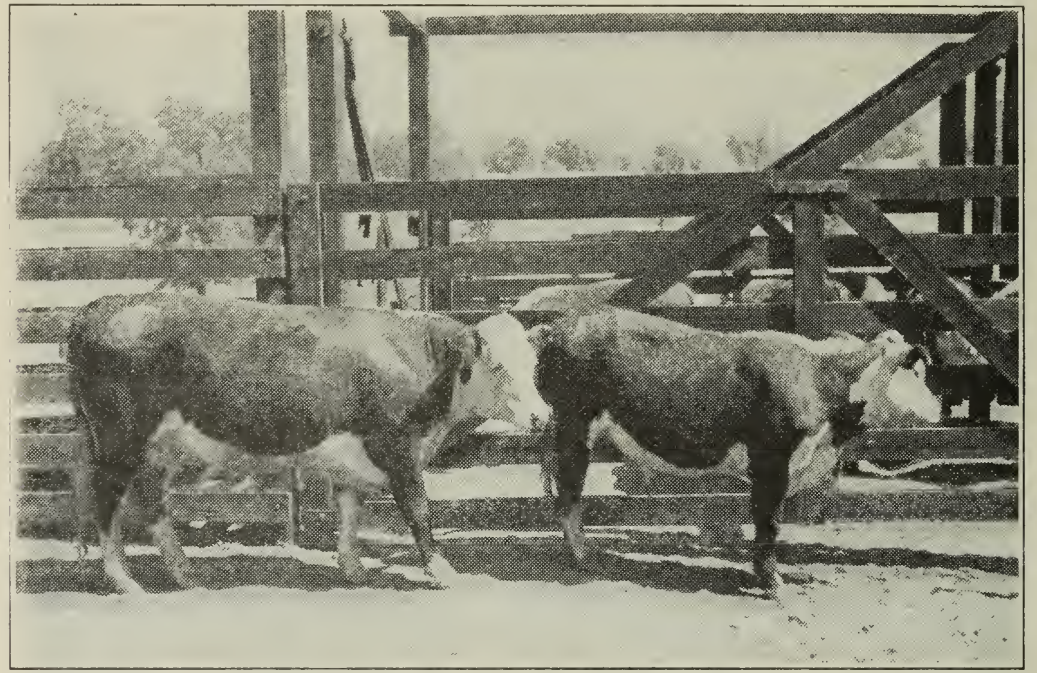

Fig. 13.-A steer of group A6, on the left, and one of group B6, on the right, at the time of marketing group A6, August 7, 1938. The weight of each of these steer's was the same as the average for their respective groups.

of the larger-sized pastures. The net gain was the same in pasture 1 as in 4 , a field containing twice the acreage. Pasture 2 produced larger calf gains and gains per animal unit than either of the largest pair of pastures (4 and 6).

The highest net gain per acre was produced by pasture 1 , in which the forage was well utilized; yet the gain during the green-forage period and the loss in the dry period were not significantly different from those of the larger pastures. In pasture 3, on the other hand, feed shortage early in the season and greater losses during the dry-forage period resulted in lower net gains and returns per acre. The lower gains, the thinner condition of the animals, and the poorer development of replacement heifers show that the degree of feed utilization was beyond optimum for the well-being of the animals and for maximum net returns. The predominance of heifer calves in pasture 3 may partially account for the difference in calf gains on this as compared with other pastures. 


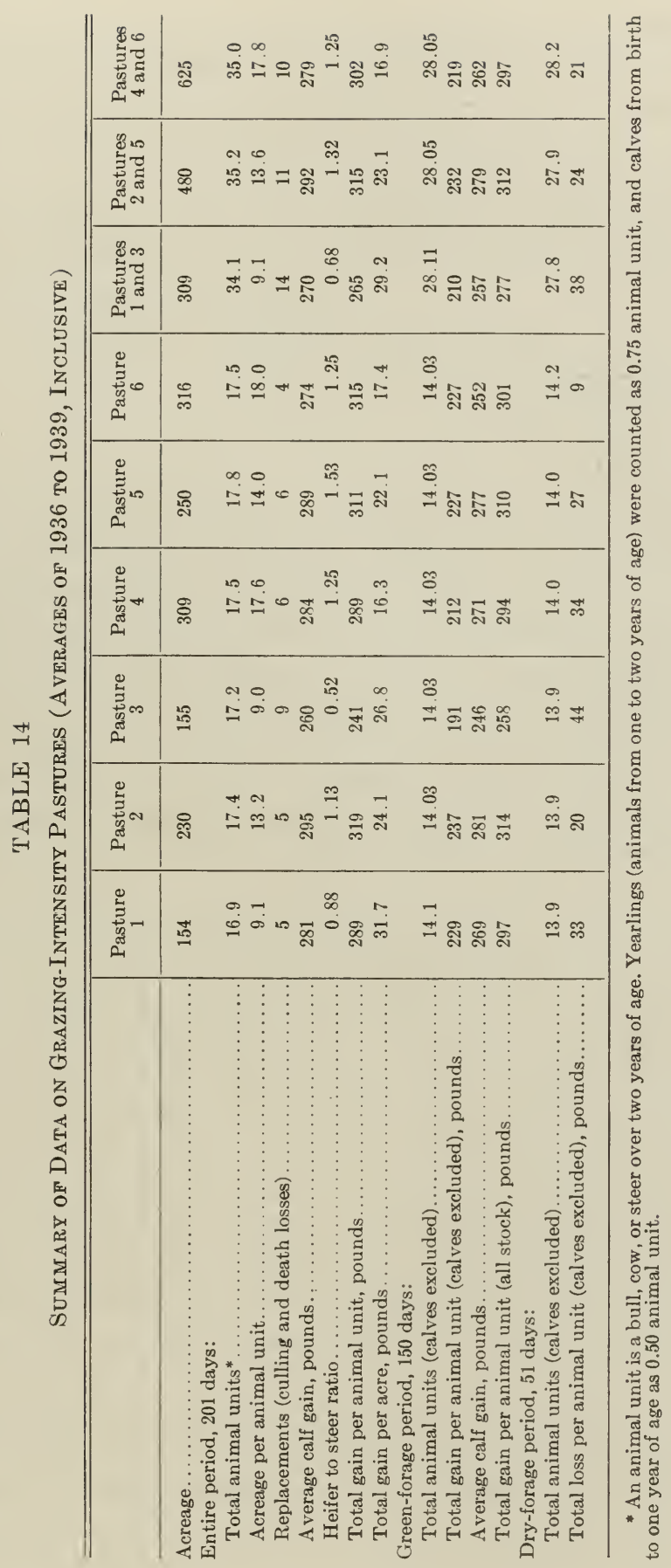


From the standpoint of degree of forage utilization it was agreed that on the average during 1937, 1938, and 1939, pasture no. 2 (medium sized) and no. 6 (large) were lightly grazed; pasture no. 1 (small), no. 4 (large), and no. 5 (medium) were moderately grazed, and pasture 3 (small) was closely or very closely grazed.

The average net gain of cows and heifers and of calves in relation to degree of forage utilization for this period is shown in the following tabulation:

Average net gain per animal unit, cows

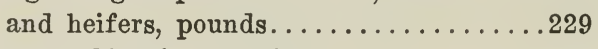

Lightly grazed Moderately grazed Closely grazed (pasture nos. (pasture nos. 1, (pasture 2 and 6 )

Average calf gain, pounds..........271

207

155

281

247

It is doubtful whether the difference in gains between light and moderate grazing conditions is significant but the difference between these and the consistently lower gains made under close grazing are obviously significant. From the livestock standpoint it is definitely indicated that the maximum utilization compatible with maximum gains during the green-forage season and minimum losses in the dry season gave greatest returns during the period under consideration. This optimum degree of utilization from the standpoint of the livestock corresponded approximately with moderate use as defined in the chapter "The Forage Crop and Its Management." The data again show that in the absence of legumes the dry forage, regardless of acreage, will not maintain the animals.

Grazing Habits of Cattle.-Observations of cattle show a close relation between their grazing habits and seasonal variations in forage composition, sequence in appearance or maturing of various species, and climatic conditions as presented in the preceding general section.

Generally, broad-leaf filaree appears about 2 days after the first substantial fall rain and is readily taken by the cattle in the first leaf stage. To get this new growth, the stock must eat considerable old litter. The bromes, wild oats, and fescues shortly become another item in the animals' diet. If the weather turns cold the broad-leaf filaree and other rosette-forming plants such as popcorn flower tend to lie close to the ground, and the stock must depend mainly upon the grasses and weeds such as buckthorn weed (locally known as fiddleneck) for the new forage growth.

With the advent of favorable weather for plant growth, filaree becomes the major item in the forage taken until it starts to produce seed and matures. The cattle then begin to take larger amounts of grasses, toad rush and true clovers if these are available. With the drying of the filaree, fescue, and other plants growing on the higher elevations and 
shallow-soil areas the cattle begin grazing the maturing soft chess heads if the season has favored their development.

After that source of feed has been exhausted or has matured, the cattle turn to the swale areas containing slender-leaf rush, the major remaining source of green forage. These areas are then heavily grazed until bare. If the season is favorable for late-growing plants, these species are also taken until exhausted or until they have matured. After complete maturing of all forage, soft chess (which does not shatter its seeds so readily as other plants) and fescues are the principal source of forage until new growth appears. When available, Spanish clover is also sought out and licked off the ground. Yellow tarweed, one of the two major late-growing weeds, is taken in substantial quantities in its early stages of growth.

Browse represented only a small part of the forage consumed. Blue oak was the principal species taken, followed in importance by coffeeberry, hollyleaf buckthorn, wedgeleaf ceanothus, and interior live oak.

During all seasons the cattle had two general grazing periods during daylight hours. The first, starting at daylight, continued until various times in the morning. The second began in the afternoon and continued until dark except during the periods of bright moonlight, when cattle grazed until midnight or later. Generally water was taken at midday (when some grazing may be done) or just before the afternoon grazing period. The cattle spent considerably more time grazing during the cool fall and winter months, when the feed was short, than in late spring and summer after the feed became abundant and the temperature was high. During the cool months the cattle generally bedded down about midmorning and did not graze again until early afternoon. After the daily temperature became high, the cattle would bed down at 8:00 a.m., or earlier and would do little grazing again until 4:00 p.m., or later. If they watered at noon they often grazed a little on their way to the water troughs.

This range land at the time of purchase was heavily infested with rattlesnakes; and despite a more or less continuous campaign against them, a study discussed in a later section has shown a population of approximately one snake per acre. In two instances grazing animals were observed to walk directly over rattlesnakes while grazing without either's paying any attention to the other; the snakes did not rattle. A defanged snake was released near a group of cattle. Its movement and rattling attracted the attention of the animals, which approached and smelled it. The snake then actually struck the animals without their manifesting any fear.

A total of 21 cattle were known to have been bitten, of which 3 year- 
lings died; 5 developed abscesses requiring treatment; and 2 were so disabled that they were culled from the herd. Of the 21 animals bitten 18 were struck about the head, 1 on a front leg, 1 on a hind leg, and 1 on the udder.

In one instance loud breathing called attention to a six-months-old calf partially hidden in a clump of brush. The animal had evidently been bitten by a rattlesnake a short time before, and the enormous swelling about its head and throat made breathing difficult. Its eyes were swollen

TABLE 15

Total Salt Consumption in Grazing-Intensity Pastures

\begin{tabular}{c|c|c|c}
\hline $\begin{array}{c}\text { Pasture } \\
\text { no. }\end{array}$ & Location of lick & $\begin{array}{c}\text { Total } \\
\text { consumption } \\
\text { in pounds }\end{array}$ & $\begin{array}{c}\text { Consumption } \\
\text { per animal unit }\end{array}$ \\
\hline
\end{tabular}

1938

\begin{tabular}{|c|c|c|c|}
\hline 1 & Inconvenient. ....................... & 88 & 4.86 \\
\hline 2 & Inconvenient.............. & 58 & 3.22 \\
\hline 3 & Convenient. . . . . . . . . . . . . & 115 & 7.03 \\
\hline 4 & Convenient........................ & 123 & 6.64 \\
\hline 5 & Convenient................... & 105 & 6.01 \\
\hline 6 & 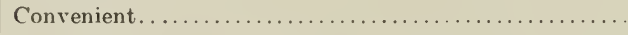 & 93 & 5.58 \\
\hline
\end{tabular}

1939

\begin{tabular}{|c|c|c|c|}
\hline 1 & Convenient . . . . . . . . . . . . . . . . & 163 & 9.64 \\
\hline 2 & 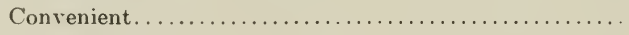 & 189 & 10.86 \\
\hline 3 & 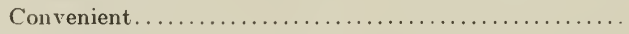 & 203 & 11.80 \\
\hline 4 & Inconvenient $\ldots \ldots \ldots \ldots \ldots \ldots \ldots \ldots \ldots$ & 56 & 3.20 \\
\hline 5 & 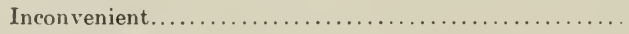 & 91 & 5.11 \\
\hline 6 & 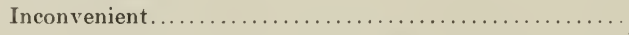 & 87 & 4.97 \\
\hline
\end{tabular}

shut, and blood trickled from the inner canthus of both eyes. The tongue protruded from the mouth. Although death then appeared imminent, $1 \frac{1}{2}$ hours later the calf had improved; and 8 hours later it was out of danger and recovered completely without treatment.

Observations on Salt Consumption.-Until August, 1937, coarsely ground stock salt had been kept available for the various groups, but large amounts were lost by leaching in the rainy season. During the remaining time covered in this publication, block salt was used in the rainy season, coarse-ground salt the rest of the year. A record was maintained of salt consumption in the various pastures. Table 15 gives data for the six grazing-intensity pastures.

Although variations were made in the location of salt in the six pastures, only one salt lick per pasture was supplied. In the beginning the salting place was chosen mainly with regard to convenience in servicing. The size of the pasture proved to be a minor point compared with con- 
venience of the lick as a factor influencing the average salt consumption. Table 15 shows the difference in salt consumption when the licks were alternated between locations convenient and inconvenient from the standpoint of normal movements of the cattle.

The placing of salt in least utilized portions of the pasture had little influence on frequency of movement of cattle into these areas. The cattle at times became noticeably salt hungry before they went to inconveniently located licks. The daily requirements for water and the convenience of securing a "fill" of feed apparently were major factors influencing grazing habits and movements. No indices used in this work, including appearance of the eattle, weight, grazing methods, or others, indicated that high salt consumption was physiologically desirable. Such consumption may, indeed, be evidence of poor feed conditions and of depraved appetite caused by deficiencies other than common salt. For example, the supplement-fed groups consumed 25 to 50 per cent less salt in the fall and winter of 1937-1938 than the others.

Analyses of Range Forage Samples.-Throughout the period a careful attempt was made to collect samples representing the actual forage grazed. To accomplish this, one of the authors did practically all the collecting. Following various quiet animals while they were grazing, he noticed the plants and parts of the plants grazed. Then he attempted to duplicate this grazing by hand from the edges of the same spots to get representative material for analysis. This procedure was followed almost daily the first two years and at weekly intervals thereafter. The collections were composited over a two-week period to consitute the laboratory samples. After the specimens were collected, dried, and composited, a broad ocular estimate of the general botanical composition, the quantity of old feed from the previous year, and any other pertinent data were recorded. About 200 such samples have been analyzed. Data on crude fiber, crude protein, calcium, and phosphorus are presented graphically in figure 14.

The data for 1936 and 1937 are averages of duplicate series of samples collected from pastures 2 and 5 during the grazing periods and from 11 and 12 during the supplement periods. The 1938 data are averages of duplicate series from pastures 2 and 3 and from 13 and 14 during the grazing and supplement periods respectively. The 1939 samples are a single series collected from all the grazing-intensity pastures and from pastures 13 and 14 during the latter part of the year.

The seasonal variation in the chemical composition of the forage was not significantly different during 1936-1938. The protein early in the season, and after old feed was no longer taken with the new, varied from 20 to 25 per cent of the dry matter. The amount declined similarly in all 
three years, reached 10 per cent early in June and about 5 per cent by July 1 . The fiber increased as the protein decreased; and the nitrogenfree extract, which is not shown in figure 14, remained fairly constant. The increases in protein and the decreases in crude fiber during August and September coincide with the time the cattle were changed from the
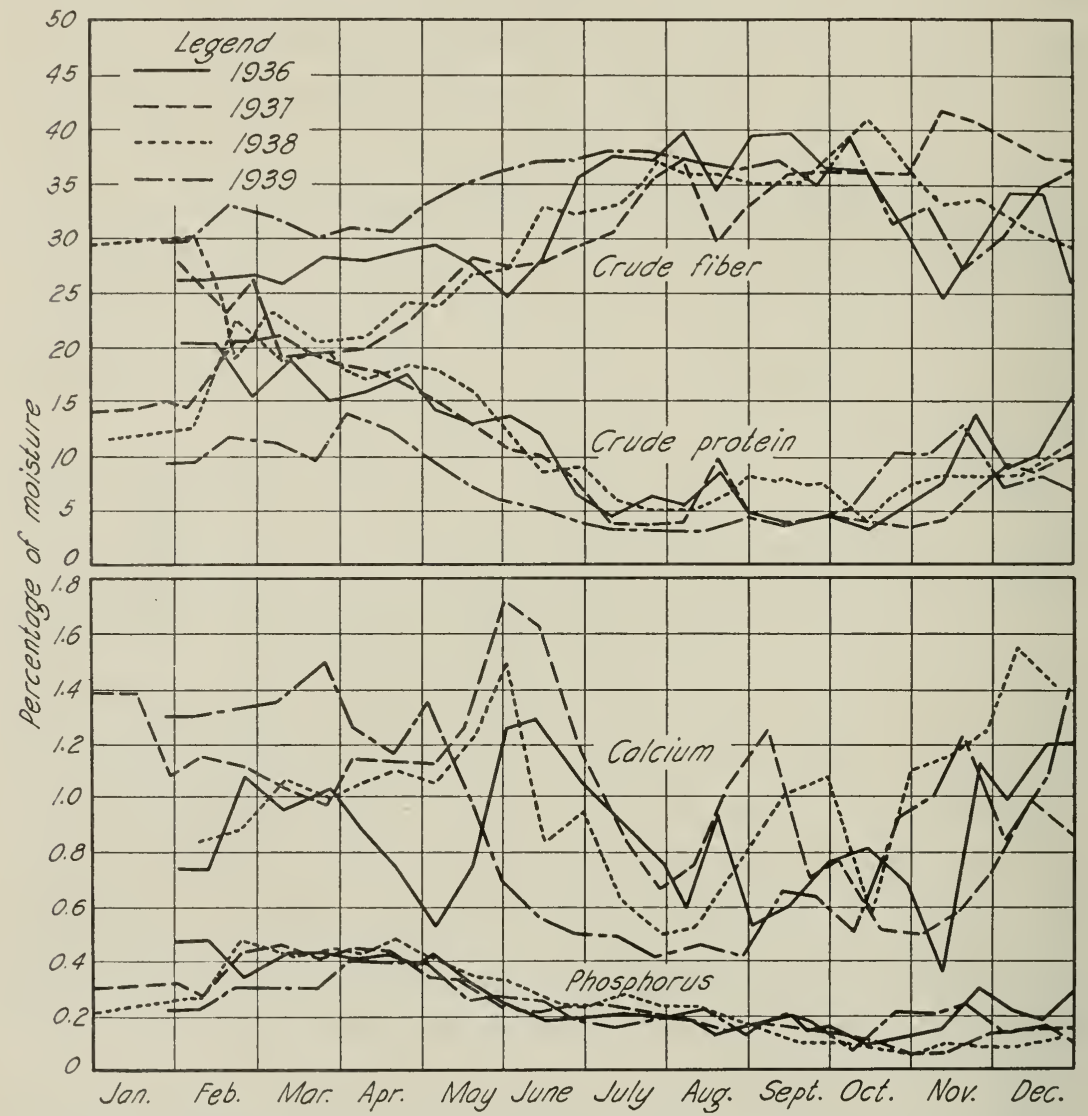

Fig. 14. - Seasonal variation in chemical composition of forage samples collected to represent forage grazed by the cattle during 1936 to 1939 inclusive.

grazing-intensity pastures to the fall holding pastures. During the first few weeks in these ungrazed pastures, enough Spanish clover and other legumes were present to improve the value of the forage. The change from a diet largely of grasses to a mixture containing the legumes is also reflected by the rise in calcium content of the sample.

As figure 14 shows, the forage in 1939 was conspiciously different in seasonal trend of chemical composition from that in previous years. Filaree made up much of the forage during the growing season-a fact 
that explains the unusually high calcium content of the samples. The protein, varying from 10 to 15 per cent during the growing season, was much lower than in other years. Because of lack of rain, the feed dried early; the protein reached a level of 5 per cent by the first of June and remained below this level until rains fell in October. The crude fiber was correspondingly high. After the forage dried, grasses made up most of the feed taken. The low calcium, characteristic of these grasses, is shown in the graph. The absence of the sharp rise in calcium in May that occurred in other years is a result of lack of late-developing species such as Spanish clover.

The phosphorus picture for the various years was similar. The longest period when phosphorus may have been a limiting factor was in 1938, when the amount dropped to 0.10 per cent or lower from the latter part of September until late in November.

Calcium content is more erratic than the other constituents studied. The changes reflect alternative grazing on grasses and grasslike plants, low in calcium, and on high-calcium plants such as filaree, legumes, and other broad-leaved species, as discussed under grazing habits of the cattle. The amount of calcium supplied was adequate at all times.

In general, protein deficiency coupled with the low-energy value indicated by the high fiber content is doubtless the chief limiting factor for producing gains. The weight records of the cattle show that gains cease and losses begin when the protein content falls below 7 or 8 per cent.

During 1938, a series of forage samples was collected from each of pastures 2 (lightly grazed) and 3 (closely grazed). The seasonal trend from early stages to maturity was the same in both series; there was, however, a consistently higher fiber content and lower protein content in the samples from closely grazed pasture 3 throughout the season. Thus there was no evidence that close and frequent grazing maintained the forage at an earlier stage of development such as usually occurs with close grazing of perennial forage. Apparently these annual plants tend to mature and produce seed regardless of the amount of vegetative growth permitted.

Acorns as Range Supplements.-Livestock men in the area attribute the following conditions to heavy feeding on acorns in years of heavy mast: deformed calves, loss in weight, gain in weight, abortion, and death from impaction.

In 1936 there was a heavy acorn mast, and the three animals kept from the original group for replacement purposes had not been used. They were in different stages of pregnancy $-4,5$, and 7 months, respectivelywhen an experiment was started to feed them acorns with the natural 
dry feed. Beginning August 1, 1936, the acorns, harvested green from the trees, were fed with the cups intact. Later, as the nuts ripened and fell, they were collected from the ground; and at that time the cups were not attached. Feeding started at the rate of 3 or 4 pounds per day, and, as the acorns ripened in September, consumption rose to 14 or 18 pounds per head daily. There was marked difference in the palatability of the acorns from different trees, although all were of the same blue oak species (Quercus Douglasii). After green feed became available, consumption increased to as much as 37 pounds in one day for one cow.

During a 60-day period on dry feed, the acorn supplement resulted in an average loss of 150 pounds per head in contrast to an average of 20 pounds per head by the group B animals not fed the supplement. Normal calves were born to two of the animals. The one animal which was 5 months pregnant when the acorn-feeding started, gave birth, at the end of 117 days, to a bull calf weighing only 31 pounds. This calf had short legs and was humpbacked in the dorsolumbar region of the spinal column. It lived until three years of age, and meanwhile the deformity became more marked.

The last animal to calve did so after green feed became available. Although she continued to eat acorns in large quantities, she regained from the third to the fifth month all she had lost in the first 2 months on the dry-feed and acorn ration.

These results agree with other evidence that acorns ingested with additional protein supplements will not cause weight losses. Since we also have evidence of deformed calves from cows not having contact with acorns during gestation, evidently acorns cannot be considered the primary factor in causing the deformity. The anatomical anomalies of "acorn calves" appear to be similar to those produced in chicks and rats by manganese deficiency. No evidence, however, of deficiency of this element in forage produced in areas where the deformity occurs has thus far been obtained.

\section{DISCUSSION OF RESULTS WITH THE EXPERIMENTAL HERD}

Because of the seasonal variation in quantity and quality of forage, the length of the dry period, and the amount of winter growth, no definite recommendation regarding time or amount of supplemental feeding can be given. For the breeding herd, the amount fed varied from 270 to 476 pounds yearly per cow.

Without supplements, losses in weight or in condition occurred in cattle of all ages on dry forage except when first turned on such forage that had not been grazed during the growing season. With the rates of stocking employed, maintenance or slight gains were made for 2 to 4 
weeks, while the better forage was being consumed. Thereafter, regardless of abundance, the protein of the dry forage was low, the fiber content was high, and weight losses ensued unless supplements were fed.

The practicability of maintaining the breeding herd in thrifty condition yearlong on this range by supplemental feeding has been demonstrated. Such feeding resulted in higher average percentage calf crops and permitted early calving of uniform-aged calves that attained a weight of 430 to 501 pounds when weaned at 7 to 8 months of age. These early calves received ample milk and had full advantage of the entire season when forage was good and when, in their development, the impulse to grow is greatest, as is shown by normal growth studies (8). They attained sufficient size and development to utilize the poor dry forage after weaning, and cows were spared the drain of lactation for a long time on dry forage. The disadvantage of weaning in July lies in the relatively long period requiring supplements, needed to continue normal development until the next green-forage season. The optimum time for ealving on this and similar ranges should be further investigated.

Even on dry forage, little trouble was encountered with difficult calving and with retained placentas in cows and heifers receiving supplements. Serious difficulty in this respect occurred with the herd not receiving supplements, and death loss was higher. Breeding the females which did not receive supplements, somewhat later, would probably be advantageous ; this postponement was expected to occur naturally as the experiment progressed. There was some tendency for cows in this group that calved regularly to breed later in the season. Many, however, failed to breed during the four months' period allowed; and they, being dry, developed good condition and again bred early the following year. The tendency to shift the breeding period later in the season was thus offset.

The labor involved in feeding supplements to the cows was little, if at all, greater than the labor involved in a careful supervision of the other group, because of frequency of retained placentas, death losses, and the like. Evidence from these data and other observations would tend to support the probability that low protein intake is associated with increased incidence of retained placenta.

Feeding supplements on alternate days reduced labor without noticeably reducing the effectiveness of the supplements as compared with daily feeding.

After 2 or 3 months on dry forage the cattle not fed supplements tended to become light red or yellowish red, in contrast to the dark-red color and smoother condition of hair maintained by the supplement-fed groups. An animal in a supplement-fed group that refused to eat supplements could almost invariably be distinguished at a distance by this color 
characteristic. Cattle not fed supplements were also usually slower in shedding.

Because of lower calf crops and the chance occurrence of a smaller proportion of heifer calves from the groups not receiving supplements, there has not been, thus far, so much opportunity for selective culling and replacement in these groups as in the others. Moreover, animals in the groups not receiving supplements are usually thinner and less well developed, a fact which renders judgment of them difficult and uncertain.

A certain environmental standard, mainly determined by feed conditions and plane of nutrition, is necessary for satisfactory progress in the improving of quality through breeding. Breeding for the higher market grades is an important factor in the ability of feeders to utilize profitably the feed in feed lots. Its continued absence in any given area reduces the value of the feeder cattle.

Insufficient data are available to show definitely the relative economy of the supplemental feeding employed with group A replacement heifers as compared with no supplement or more limited supplemental feeding. There was no significant difference in the percentage of first calves dropped, but there was a wide difference between the groups in weights of calves at weaning and in second-calf-crop percentage. These advantages, combined with the additional weight of the supplement-fed heifers, must be considered in comparing the two methods of management.

Weaner calves were fed amounts of supplements varying in the different years from 286 to 597 pounds over periods of $61 / 2$ to 8 months. The average daily gain varied from 0.55 to 0.75 pound for those receiving supplements as compared with a little more than maintenance on the average in the others. The final weights of the former at the beginning of the green-pasture season varied from 550 to 650 pounds; the latter from 345 to 495 pounds. This difference was decreased somewhat during the subsequent pasture season, and a limited amount of data indicated this to a greater extent in the heifers than in the steers. Not only weights and feed costs, but also variation in the value of the animals per pound, should be considered in evaluating the data.

The possibility of producing good-grade slaughter steers as long-yearlings and as two-year-olds through supplemental feeding has been demonstrated. The practice, though economically feasible thus far, is not necessarily the best use of such land. It involves a certain amount of chance determined by weather, price of feed, and market price of the finished animals. The data on finishing are significant as indicating means of maximum utilization of grass in the production of slaughter cattle desirable in weight and finish on ranges better adapted than the experimental area is for fattening cattle. 
Since heifers fatten more readily than steers at the yearling stage and sell to better advantage at this age than later, supplemental feeding to finish surplus heifers on this and similar ranges appears practicable.

Experience indicates that without supplemental feeding, two-year-old steers cannot be depended upon to reach slaughter condition. The evidence also supports the view that this and similar areas will sell most animals of the various ages as feeders even when supplemental feeding is practiced.

Attention is called to the possibility of producing and marketing heavy feeder calves at weaning time through liberal supplemental feeding of the cow herd and by early calving. Fluharty (3) shows this to be economically feasible only when percentage calf crop is high and heavy weights are obtained. Under such a system supplement-feeding is limited to the breeding herd and to a shorter period than that required by calves carried over from weaning to the next green-grass season. Such calves, however, make continuous gains when fed supplements and offer another means of marketing the range feed through sale of 800 - to 900 -pound fleshy long-yearling feeders at the end of the green forage season.

The data from these experiments, in common with general experience, show that greater gains are made during the yearling than during the two-year-old stage.

Except for one group of cattle fed fish meal and molasses, the locally produced supplements, cottonseed cake and barley were used. Because of the protein deficiency of the range, a protein supplement is a first consideration. Protein supplements also furnish phosphorus and added energy. Because these feeds are usually higher priced than barley or other grains, the latter can be used for additional energy after protein requirements have been met.

Abundant information is available on replacement value of various protein concentrates that may be substituted for cottonseed meal and other grains, and of by-products that may be substituted for barley. This information, summarized by Guilbert and Rochford (10), may be utilized in selecting alternative feeds in case cottonseed cake or barley prices become discouragingly high.

According to evidence from the study on the six grazing-intensity pastures, reduction of individual animal production by excessive stocking in relation to feed supply may be such that returns per acre are likewise reduced. The results also show that grazing over a 6 - to 7-month period to an extent designated as "moderate to close" produced gains per animal unit comparable with those resulting from light grazing; and the return per acre obviously was higher. The data suggest that the concept of maximum forage utilization compatible with maximum produc- 
tion per animal unit has possibilities of wide application for defining proper rates of stocking from both economic and ecological standpoints.

A policy of maintaining a hay reserve as an insurance against extreme drought and feed shortage has been adopted, on the principle that such feed under cover could be kept for many years without much depreciation, whereas feed on the range is spoiled from year to year by rain and exposure. Hay reserve thus permits as complete utilization of the range in average years as is compatible with its maintenance and the well-being of the animals without the hazard of feed shortage and high feed costs under extreme conditions. Apparently about 50 per cent more acreage is required to carry the cattle from August to February than from this time until August 1. 


\title{
RANCH ORGANIZATION AND MANAGEMENT IN THE GRANITE AREA
}

\author{
E. C. Voorhies, L. A. Crawford, R. L. Adams, \\ AND G. A. CARPENTER
}

THE DIScussion under this heading describes the general ranch management practices in the region surrounding the San Joaquin Experimental Range (fig. 15). The area covered by the survey totals approximately 500,000 acres situated in Madera, Mariposa, and Fresno counties. It is fairly typical of the foothill belt of the Sierra Nevada in which some of the most pressing problems of livestock production are met.

The "granite area" derives its name from the frequent and often substantial outcroppings of granite found throughout the section. Landsurface features of this type are found to extend in a southeasterly direction from the town of Mariposa for approximately 50 miles, and from the open range or "bald hills" section bordering the San Joaquin Valley floor in a general easterly direction to the present boundary (1940) of the Sierra National Forest. The width of the area varies from about 6 to 20 miles.

While the granite outcroppings give the region a fairly uniform appearance the topography varies greatly. Low hills, broken slopes, ravines, and small valleys are found. The elevation rises from an altitude of approximately 700 feet above sea level on the western border ("bald hills" section) to about 3,000 feet on the eastern border. The valleys are relatively small, tortuous in contour, and widely different in soil. Some of the land is arable, but by far the greater part of the acreage is suitable only for livestock grazing.

Three principal rivers drain the area-Chowchilla, Fresno, and San Joaquin. Only the last-named has an appreciable flow during the entire year. In all of the streams the largest flow occurs in the late winter and early spring months. With the exception noted above, most of the streams are dry at some time in the late summer or fall.

Development of the Cattle Industry.-The beginnings of the cattle industry here date back to the period shortly after the discovery of gold in 1848. During the next two decades this and other foothill areas in central California attracted a large influx of miners. The population of the region was probably greater at that time than at any period since. There were numerous operators using the public range at the time, supplying meat and dairy products to the then important mining communities. Such enactments as the Homestead Act (1862) were utilized to acquire meadows and key tracts which might be used for the control of 
the public range. As numbers of cattle were increased the use of range gradually expanded both in the foothills and in the higher mountains to the eastward, the latter area being utilized in the summer months.
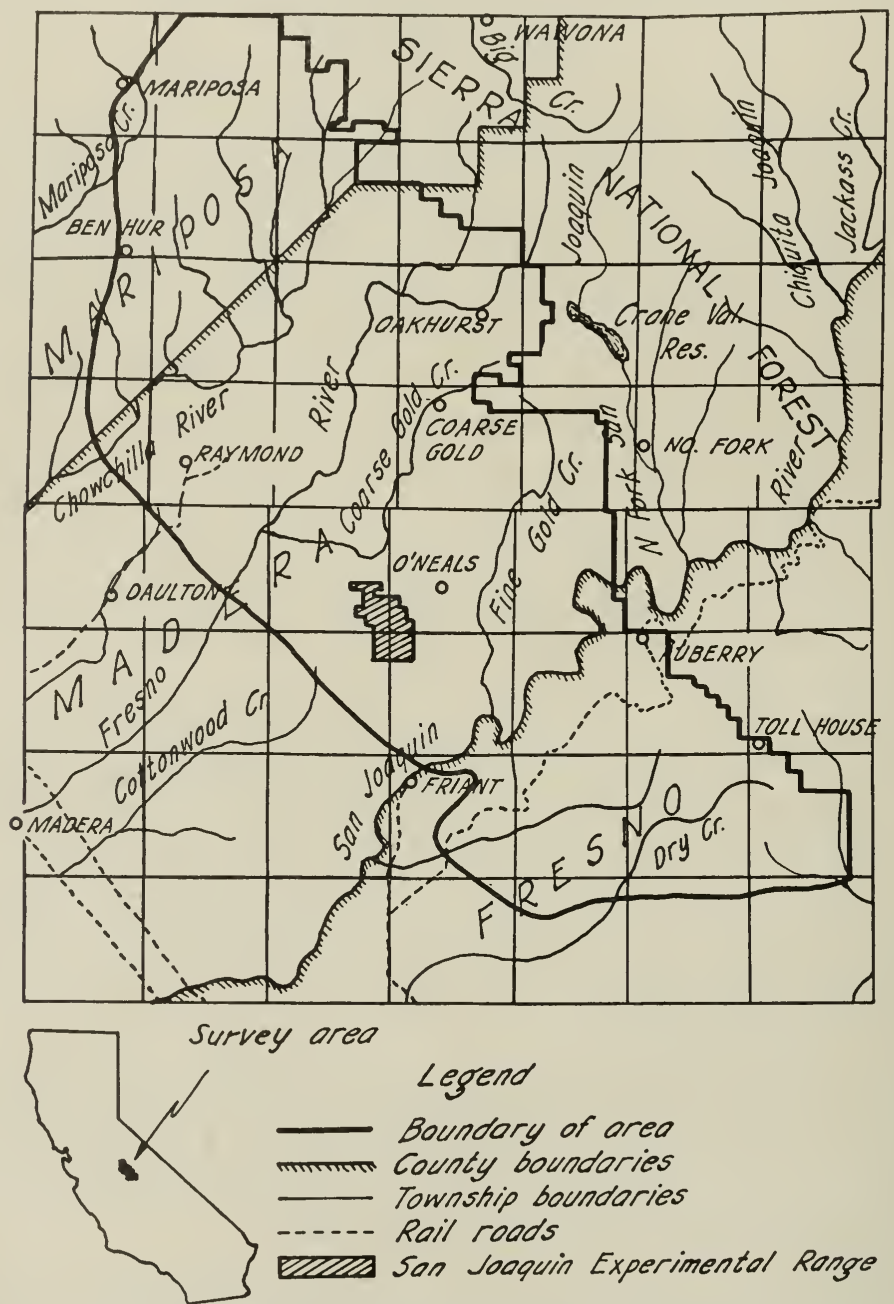

Legend

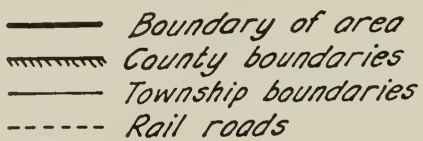

Eele San Joaquin Experimental Range

Fig. 15.-Part of the granite area surveyed in the study on ranch organization and management.

Prior to the gold discovery, settlement had not taken place here. An important change occurred in land tenure, the early range being "free." This gradually changed so that a considerable part of the range was transferred to private individuals. Numerous enactments by the Congress after the passage of the Homestead Act, for example, the Timber and Stone Act (1878), the Enlarged Homestead Act (1909), and the 
Stock-Raising Homestead Act (1916), enabled settlers to obtain private holdings in many cases considerably larger in acreage than was allowed by the Homestead Act of 1862 . Considerable land was acquired through mining claims. By the very manner of acquisition, resulting holdings were small. There is no doubt that many of those who engaged in cattle production did so only after the exhaustion of their gold deposits. While there have been consolidations of "ranches" or farms in the area by either lease or purchase, there are still many small units—too small for efficient operation.

About the same time the small operators were occupied in founding small herds for the supplying of the mining communities, larger operators came into the San Joaquin Valley to the west. The herds of the latter were kept in the San Joaquin Valley for most of the year, grazing in the lowlands after the rains started the grass. These men moved to the foothills and mountains with their herds after the feed of the valley was gone, and remained at the higher elevations while the feed lasted. Both the smaller and larger beef cattle operators are found here until the present day. There is, however, one great change which has come about: the small operator once had his consumer at his door-today he does not have the same market since the miners have in most cases departed.

The type of farming carried on in an area is usually the resultant of two sets of determinants-natural and economic. The natural conditions may be placed in three main categories-soil, topography, and climate. In the granite area the lands are thinly forested. The soils vary from fair to poor and are nonirrigable and somewhat droughty. Even with a climate which might be suitable for certain crops the soil conditions and, to a large extent, the topography favor livestock production. Some hay is produced and on some of the farmsteads suitable areas are utilized for the growing of fruits and vegetables for local use. Where the foothills shade off into the Great Valley some grain is grown-but these localities are really outside the granite area.

The chief economic forces which unquestionably have influenced the development of the beef-cattle industry in the region have been the varying demand for beef, and labor conditions. In addition, such factors as the size of the enterprise, calf crop, death losses, and indebtedness in the area itself have had a marked influence. Since the beginnings of the beef-cattle industry here, no doubt the experience, training, capabilities, and desires of the operators have been influencing factors in the development of the enterprise in the area.

Size of Business.-Both the acreage controlled and the number of cattle held vary widely. Variations in holdings range from 100 to close to 20,000 acres while the number of cows kept by individuals vary from 4 to over 400 . The term "average holding" for this area is meaningless. 
By far the greater number of operators control less than 3,000 acres, yet the distribution by acreage up to this amount does not cluster about any mean. A similar wide variation exists in the number of breeding cows kept. On 88 ranches out of a total of 185 from which data were obtained less than 35 breeding cows are kept while on 41 ranches over 100 are kept.

Composition of Cattle Holdings.-Data on the composition of cattle holdings on 37 of the ranches surveyed were obtained in 1936-37. The total number of all classes of cattle was 8,658 grouped by percentages as follows : yearling heifers, 9.8 ; yearling steers, 9.4 ; two-year-old heifers, 2.1 ; two-year-old steers, 8.5; cows three to seven years old, 38.9 ; older cows, 5.1 ; calves, 14.5 ; weaners, 8.5 ; bulls, 2.1 ; aged steers, 0.9 . These percentages varied on the different ranches. A statistical separation into groups of different sizes did not reveal a definite trend in these classifications.

Size of Breeding Herd.-The total number of cattle handled by stockmen fluctuated considerably as the result of available range, winter feed supply, cattle prices, and other factors. The number in the breeding herd seemed to remain fairly constant, but the latter varied so greatly from ranch to ranch that the average of 91 is of little significance. Small herds predominated; 144 out of the 185 from which data were obtained had less than 100 breeding cows, and of these, 88 herds had less than 35 cows and 56 from 36 to 100 cows. Of the 41 herds with over 100 breeding cows, 26 had from 101 to 200 cows, and only 15 ran over 200 . The larger part of the operators with small herds were "part-time" farmers. Their livelihood was obtained from road work, woodcutting, government aid, and working for neighbors, in addition to the keeping of the herd of beef animals. Most of the operators having more than 35 or 40 cows relied chiefly upon the income from the cattle as the source of livelihood. While some of the latter operators may have had one or two additional side lines, their main business was raising beef.

From observations and questioning, it appeared that from 100 to 125 cows constituted a herd which required the services of an owner to be fully utilized-perhaps with the hiring of additional labor during certain seasons of the year-or in which the labor of the family was utilized.

The outfits with over 200 head of breeding cows usually controlled large units of range land, and as a rule employed from one to three men in addition to the operator during a part of the year. In the main, this latter group was composed of the older settlers, whose holdings have been acquired over a considerable period of time.

Land Tenure.-Of the 185 ranches from which data were collected, over half (96) were handling a combination of both owned and leased land; 81 owned land which they operated; while 8 were tenants. Gen- 
erally speaking, the smaller operators leased a smaller percentage of their holdings than the larger ranchers. The leased land was acquired from private individuals and from federal, state, and county governmental agencies. Approximately a third of all the operators used national forests for pasture from three to five months. As a rule, the operators with the larger number of animals more frequently utilized the national forest.

The acreage of the ranches from which data were procured included 350,202 acres, and of this area approximately a third was leased. Less than 10,000 acres was recorded as crop land. The crop land is devoted largely to growing oat hay, which is used for horse feed and during the winter months for some of the poorer range cattle.

Somewhat over half of the leases were for a one-year period. Frequently leases were renewed by the same parties. The majority of the lessors were nonresident owners.

Rental price varied, the amount depending largely on the physical features, forage, and location. In the year of study, prices varied from $\$ 0.10$ to $\$ 1.00$ per acre, with an average of $\$ 0.31$. Highest rentals were paid for land in the slate formation bordering on the granite while the rough land with granite outcroppings rented for the lowest price. Several operators have had access to certain lands in return for the payment of taxes and the upkeep of fences. The average assessed valuation of range lands in the area ranged from approximately $\$ 2.50$ to $\$ 3.00$ per acre. The tax rate per $\$ 100$ of assessed valuation was $\$ 1.17$ and $\$ 1.18$ in Madera and Fresno counties, respectively, for lands classified as being outside of special assessment districts. The tax would therefore range from about 2.9 to 3.5 cents per acre.

Feeding Practices.-Information on feeding practices obtained from a cross section of over a hundred (105) ranchers in the area indicates a variation from ranch to ranch according to the physical setup of the range controlled, the resources of the operator, and other conditions. Of the 105 ranchers, 15 stated that year-round grazing is the only provision for feed. The remaining 90 use some supplementary feeds, consisting of grain hay, cottonseed cake, and barley-the latter two being fed separately or in combination. Among those using supplements on the range, the prevailing practice is to feed breeding animals and other stock in poor condition in order that the winter might be survived ; as a result supplement-feeding is confined to the one or two months' period from the time the rains damage forage until green grass becomes available. Only 8 of the 105 operators interviewed do any finishing of cattle for market. Hay, cottonseed cake, and barley are used for such feeding.

Almost half of the operators (49 out of 105) use a system of seasonal 
grazing. Cattle are held on the lower foothill ranges during the winter months, and frequently supplement-feeding is practiced. When the green feed gains strength, the cattle increase in weight and condition; some steers and older cows are salable as grass-fat cattle. With the advancing season and the subsequent drying of the grass on the lower ranges, the stock are moved to range at higher elevations. If the operator holds a grazing permit, he moves the allotted number into the national forests. Normally cows and calves are sent but in some instances other stock are included.

Operators owning or controlling range at both lower and higher elevations have access to green feed for longer periods, since the growing season of range grasses is about two weeks later on the average for each 1,000 feet increase in elevation in this area.

The majority of those practicing year-round grazing on owned and rented land, or both, are largely operators of small herds. A number attempt to rotate pastures for their stock. Others, limited largely to a few part-time operators, graze the entire holding throughout the year.

About a third of the operators graze stock in a national forest for from three to five months. Most of these persons possess herds of over 36 cows and many of them are dependent upon the continuance of forest permits to remain in business. In addition to lands in the national forest, approximately 15,000 acres of Indian lands are grazed by Indians or by ranchers having access to such lands.

In the investigation made for 28,074 cattle on ranches from which adequate data were available, the private range furnishes slightly less than 92 per cent of the total grazing, while somewhat over 8 per cent is supplied by the national forest.

Stocking the Range.-In an area of varied topographical soil conditions and conditions of management, there are differences in the number of acres of range per animal within the area itself. Some units are overstocked, while there are parts on which livestock is not grazed. The average rate of stocking, revealed from information obtained from 185 operators, is approximately 23 acres per animal unit per year. On a few of these ranges, some supplement-feeding is done during dry periods. No account is kept of the amount fed. Ranchers in the lower "bald hill" section on the slate soil report about 12 acres for each mature animal, while ranchers using some of the poor granite range require as much as 40 acres. Few of the latter require, in addition, supplements for winter feeding. With such great variation, any generalization would be difficult to make.

While the amount of land not in use is small, there are such areas resulting from the nontaking of lands of high rents, unsettled estates, 
certain Indian allotments, and certain lands occupied by individuals who are not interested or concerned with the cattle business. In certain areas, isolation and topography prevent the use of land.

When cattle prices are relatively high, it is difficult to rent range in the area. Many livestock ranchers require sufficient forage for yearlong operations. Such operators attempt to rent pastures by the acre or at a stipulated price per animal per month.

The demand for national forest range is such that all available range is being occupied. Normally, those seeking national forest ranges keep from about 36 up to 200 cows. The use of such ranges by these persons is so closely connected with the uses of private range that any serious disturbance in the permittee system would cause stockmen to make considerable adjustments in their operations. Such adjustments might be the obtaining of summer range or the feeding of supplements.

In the area, there is considerable discussion among the operators as to the difference between operations confined to the Great Valley and those in the area. The general trend of opinion is that the former operations are perhaps more expensive as far as operating costs are concerned, but it is generally admitted that they result in a higher-grade and betterfinished animal product. Only a few of the Valley operators are found among the permittees of a national forest. Some have grazing preferences and attempt to control private land within the boundaries of a national forest in this manner.

Many of the national forest ranges are poor and can be used only to aid in the production of feeder stock. Long stock drives are often necessary en route to and from these ranges. This sometimes necessitates the use of additional supplementary feeds on returning to the lower ranges. Ranchers in the Valley agree that death losses are high in the national forests. Another problem which confronts the stockman using the national forest is that in recent years there has been a great increase in roads, making considerable disturbances as a result of traffic. Some operators have avoided this trouble by trucking the cattle, but the smaller operator cannot always follow this procedure.

Breeding Practices.-In general, three different breeding practices are carried on : (1) yearlong, in which the bulls are allowed to run with the cows at all seasons; (2) semicontrolled, in which the bulls are removed from the breeding herd for from 3 to 8 months; (3) controlled, in which the bulls are segregated from the breeding herd under a definite plan of operation and in which a definite program of herd improvement is in force. By far the larger number (approximately three fourths) of the ranchers practice yearlong breeding. Almost another fourth segregate the bulls from the herd except in spring and summer. 
A very small number of ranchers select and segregate the heifers from the breeding herd and breed them as two-year-olds. Most ranchers agree that the latter is a desirable practice, but they are not equipped with the necessary pastures and ranges to separate the young heifers from the herds. The size of some herds is such that the additional labor necessary for controlled breeding is far too costly.

Types of Bulls and Breeding.-Approximately one half of the operators are using purebred bulls. The remaining half use grades or crossbreds and animals with miscellaneous blood. Some of the operators using bulls of miscellaneous blood think they cannot afford purebred sires. They often rely upon bulls of their own breeding or else pick up a cast-off or grade bull from their neighbors. Bulls turned on the national forests must at least meet the state law requirements.

Considerable crossbreeding is practiced in the area, one of the most common crosses being the Hereford bull on Shorthorn cows. The claim is that this cross results in a larger calf and a larger milk flow. Some operators buy yearling bulls and condition them before use, in order to get the bulls accustomed to the range and in good breeding condition before turning them in with the herd. This has an important influence on the calf crop and the nature of the calves, but it is considered by some ranchers to be too expensive a process.

A number of the purebred bulls are used for a longer period than is thought to be desirable. Trading of bulls in order to avoid this practice is not uncommon. Most operators plan to purchase a young bull, use him two or three years and then trade with a neighbor, who is following a similar practice. When bulls get too old to trade readily, they are sold to the butcher and replaced by younger animals. In many cases where the finances of the operator are limited, he will continue to save bull calves from his own herd which show favorable or outstanding characteristics.

Calf Crop.-The number of calves dropped averaged 79 per 100 cows maintained in breeding herds. The most startling situation, however, is revealed in examining the range in numbers of calves dropped, namely, 24 to 100 . Out of the 97 herds from which data were obtained, only 2 reported the number of calves dropped equal to the number of breeding cows. One of these herds contained 6 breeding cows, the second 65 . In an examination of the averages by size of herd, no particular difference was found between the larger and smaller herds. The figures, however, as reported, were significant in that all size groups indicated extremes from uneconomically low to substantially high percentages. The largest percentages of calves dropped per 100 cows maintained in breeding herds were observed on those ranches that either had the best range conditions or made provisions for the care of breeding cows. 
Calving Season.-The largest number of operators reported that the majority of their calves, however, were dropped during February, March, and April, although several reported calves coming in other months. There is some variation as the result of ranch location and marketing practice. Some stockmen, principally those in the lower elevations, prefer fall-dropped calves. They can ordinarily count on green feed in December and January and the resulting heavier milk flow. On the other hand, some ranchers firmly believe that calves which come early in the spring usually winter better than those which are born late. If a rancher follows the practice of selling weaner calves in the fall, he must produce early spring calves in order to gain the needed amount of weight by fall. The latter is particularly the case for stockmen who graze cattle on the national forests, in that the calves must come sufficiently early to make the trip to the mountains and also to make best use of the mountain range. Moreover, fall calves, if taken to the national forest, have sufficient age to be counted as mature animals, a disadvantage to the stockmen.

Death Losses.-Data on death losses of cows and calves were obtained from approximtaely 65 herds for the year 1936-37. The smallest percentage of losses occurred in the groups which numbered from 100 to 200 cows. The largest losses, on the other hand, were in the smaller herds of under 35 cows. The reason for the latter losses was probably because of the fact that the smaller operators were running cattle as a side line. It is only natural that operators who divide their time between some outside activities and the running of cattle may tend to let the cattle shift for themselves. For the herds from which data were obtained, the percentage of calf mortality was 6.1 per cent, while the percentage of cow mortality was 4.3 per cent, for the year 1936-37.

The heaviest losses occurred among calves and in calving two-year-old heifers. Causes for death losses were varied. A considerable loss in small calves occurred during the calving season. Losses resulting from predatory animals, dehorning, and blackleg were relatively small. Fully 90 per cent of the operators reported that they vaccinated their calves for blackleg. As a result, losses from this cause were practically nil for the period studied. Some operators reported losses from accidents. A goodly number of losses were reported as "cause unknown" or "animals missing." Many of the latter die on the range, and their carcasses are not found. Several cattlemen believe that cattle rustlers steal animals now and then, principally young unbranded calves. Two operators reported losses from eating poisonous plants, such as larkspur and black fern.

Another cause of loss which many ranchers maintain is rather serious is the eating of too many acorns by cows during gestation. It is said that 
this results in the typical "acorn calf," born with very short legs, oversized head, and undershot jaw. Some "acorn calves" also show a bloated condition. Some stockmen are sure that the situation is more serious following large acorn crops throughout the oak belt of the foothills.

The entire question concerning "acorn calves" is of a controversial nature. Research work on "acorn calves" does not confirm the ideas which many possess on the subject; investigators state that acorns cannot be considered the primary factor in the causation of the deformity. (See the section "Experimental Herd Management.")

Dehorning and Branding.-The practice of dehorning is increasing. Most operators in the area dehorn, brand, castrate, and vaccinate at the same time, most commonly in April and May. In herds where calves are dropped throughout the year, these operations are sometimes performed two or three times a year. The common practice is to brand calves before they are weaned, in order to identify ownership and thus discourage thieving.

Weaning.-Most of the calves are weaned when from six to seven months of age. Stockmen using the national forests wean their calves in September or October, or as soon as they come to the lower ranges. Being in good condition when they come out of the mountains, they can be separated from their mothers and fed a little hay or concentrate, or else placed on pasture reserved for this purpose.

Some of the smaller operators, nonforest permittees, and stockmen who do not get calves of fairly uniform age oftentimes allow the cows to wean the calves, although this practice is not generally followed. Weaning practices are usually determined by the calving period and the nature of the selling practices.

Culling Practices.-On some of the better-managed ranches, cows are culled on the basis of performance, as well as on age, type, and conformation. Cows that are shy breeders, poor keepers, or those that produce poor calves are culled. The majority of stockmen follow what might be termed a "mechanical" culling process. The process is a simple one of retaining even somewhat undesirable cows as long as they winter fairly well and continue to produce fairly good calves. Smaller operators apparently cull less consistently than others. A few of the smaller operators purchase dairy calves in the lower valleys and graze them in the foothills, attempting to grow them and eventually sell them as milk or beef stock, according to the sex of the calf. Dairy stock as a rule do not make as satisfactory gains as those made by beef-type animals on the range of the area, and as a result there are many poor animals which do not actually pay for their keep.

The average age of the cows in the majority of herds ranges from 
three to seven years. When culled according to age, cows are sold when they are nine to ten years old; cows older than ten years are uncommon.

Marketing Problems and Practices.-Available feed supplies and the condition of the range influence the marketing of cattle from this area in a material way. Some cattlemen, however, operating under a load of heavy indebtedness, must sell in accordance with stipulations which govern the granting of a loan. Normally speaking, plentiful feed and good range tend to hold cattle for a longer period of time. Conversely, when the feed is short and when the range is poor, stock cattle, as well as calves, may be sold. The market conditions also play an important part.

There are apparently two times during the year when cattle are largely marketed from the granite area. In the spring, grass-fat animals are disposed of in May, June, and July; and range-fat animals in October, after they have been on the mountain ranges. A goodly number of the grass-fat steers sold from the lower ranges in the spring go to the central markets at San Francisco and Los Angeles, where they are sold by weight. Some local sales are made to local buyers and speculators, who in turn gather their purchases at a common loading point for further shipment to the central markets. Fresno and other Valley cities take considerable numbers of cattle, and these are usually purchased direct from producers located in the area.

The majority of steers sold out of the area go as feeders, unless they have been "warmed up" by being fed concentrates for a period. There are, however, many grass-fat steers which are sold to the beef trade in the spring following the green-grass period.

Ranches can be classified on the basis of the type of production predominantly practiced, as follows: (1) Operating on a steer basis and selling steers at two years of age or over; (2) operating mainly on a cow-and-calf basis and selling weaners; (3) having no definite yearly plan but marketing animals mainly on finish and market conditions as determining factors.

Approximately one half of the operators interviewed could be classed in group 1, while groups 2 and 3 comprised the balance. A number of small operators sold their calves as veal to local Valley butchers. Since the advent of the truck and trailer, stockmen can load one or two animals when going to town, and they then can visit the various slaughtering houses or butcher shops to see where the best prices can be obtained. Many of them supply some small beef plants regularly.

While weights and prices vary from year to year, nevertheless some of the data which were obtained for 1936-37 present some interesting studies. The average weight of two-year-old steers which had been fed 
supplements in some degree at least, was 968 pounds ; the range in weight was from 800 to 1,100 pounds. The average price received for these animals was $\$ 7.20$ per hundred pounds, the range being from $\$ 6.00$ to $\$ 8.50$.

During the same year the average weight of two-year-old steers from a group of twelve ranches which depended entirely on range for maintenance growth was 825 pounds. The average selling price of these animals was $\$ 6.70$ per hundred pounds. While the comparison is not such that one can rely on the results, nevertheless it can be pointed out that the animals fed supplemental feeds weighed on the average 143 pounds more per head and they sold for an average of 57 cents more per hundredweight, because of their better condition.

During this same year the seven- to eight-months-old weaner calves ranged in weight from 300 to 450 pounds. The sale price varied from 7 to $71 / 2$ cents per pound.

Other Livestock Enterprises.-Approximately a fifth of the operators interviewed kept two or three sows. These farrow twice a year, pork for the family is obtained, and some hogs are sold. On most ranches feed for hogs is hauled from the San Joaquin Valley; therefore, hog raising is not an enterprise of any considerable importance. A very few sheep are kept but the number is so small that they can be ignored. Now and then an operator is found who milks a few cows and sells the cream. The majority maintain one or two cows for the family milk supply. Most operators keep a few chickens, in order to provide eggs for the family's use, and four flocks of over 1,000 turkeys were found.

Flexibility in Ranch Management in the Granite Area.-Cattle prices are affected by influences over which the rancher within the area or elsewhere has little or no control. Improvements in management practices aid many cattlemen in taking advantage of some marketing and price situations. Any blanket recommendations for all operators should be viewed with caution-if not with suspicion.

Operators can be in a somewhat more advantageous position if their ranch organization is such that some choice may be exercised as to class of animals to be sold; for example, whether calves, yearlings, feeders, or fat cattle. An ample supply of range for winter feeding will often make for a far more flexible program than is carried on at present; market conditions and prices of different classes of cattle can then have some determining influence on sales. For example: Are calves to be sold to the feeder trade or carried on to the yearling stage? Are steers sold to better advantage as two-year-olds or three-year-olds? In a flexible market program, operators normally would sell the type of cattle for which prices are favorable and hold those for which the demand is slight. 
Normally, efforts to keep up a breeding herd would be justified-not only because such a procedure leads to flexibility of operation, but because of the time and expense involved in bringing a new herd together. In operations in which an improved breeding herd is not important, such recommendations would be invalid.

Seasonal cattle movements into California for both slaughter and feeder purposes are fairly regular; the larger movements usually start in October and, in general, last for approximately six months. This situation results largely from the demand of the California markets and from the cattle management plans of the producers in the localities from which cattle are shipped into California. Some adjustment in local operations might be made to take advantage of this situation.

Feed prices would loom large in any increased flexible arrangement made by producers in the area. Not only must kinds of feeds and quantity be considered, but the transportation problem particularly exerts an influence on these prices in the granite area.

One of the principal problems facing the operator in the area is that of acquiring control of range that is adequate and suitably located so as to provide range units of suitable size for economic operation. The somewhat unstable short-time leasing system and high rental prices in many cases prevent not only a flexible program but in many ways present difficulties to present programs. 


\title{
INTERRELATIONS OF RODENTS AND OTHER WILDLIFE OF THE RANGE
}

\author{
E. E. HoRN AND H. S. FITCH
}

MANY FACTORS, including the climate, topography, amount and distribution of food, water, and shelter, determine the kinds and abundance of wildlife occurring on any area. The animal life thus reflects all the conditions of the region where it occurs. Some kinds, present the year-round, are adjusted in their annual schedules to seasonal changes; others are migrants which may stay only for brief periods in a given locality, or may merely pass through it. The entire wildlife population of an area is dependent for food either upon vegetation or upon other animals which directly or indirectly obtain their sustenance from plants. The economic bearing of each species is determined largely by its feeding habits.

In our foothill range lands the rodents are of most general importance because of their enormous numbers and their feeding, which largely is levied upon plants valuable as forage for domestic stock. Of the predators, some are beneficial because they prey upon rodents, although in some cases they may be destructive by preying upon cattle, sheep, or domestic animals, as do the mountain lion, coyote, and bobcat on occasion. Any study of the wildlife in an area must therefore consider many different creatures, all significantly interrelated in their influences; each, by its presence and activities, affects all the others.

An economic problem in land utilization was created when the pioneers brought domestic livestock onto ranges formerly used only by wild grazing animals. The resultant increased use of the forage effected changes in vegetation, and the newly created habitat conditions were less favorable to some kinds of wildlife but favored the increase of others. Destruction of forage by wildlife came to assume increased importance as free or cheap range lands were used up and competition in the grazing industry became keener, necessitating the introduction of more economical practices in land use.

The stockman's interest in wildlife centers in the question of what these animals do to the range. Ranchers continually ask, regarding these different animals: How much forage and what kind of forage do they take? What good they may do? Can they be removed, and how much would removal cost? Would the increased returns make control an economical practice?

With the establishment of the San Joaquin Experimental Range, the Fish and Wildlife Service (formerly Biological Survey) joined coöpera- 
tively with the other agencies in a study, designed to carry over a period of years, to determine the economic importance and interrelations of wildlife on the granitic soil areas of the Sierra Nevada foothills of California. This study is intended to bring out the relations between species of wildlife and plants, and the interrelations between different wildlife species which have bearing on the question of grazing and land utilization in the foothill ranges.

Rodent activity affects the range in many ways. Each rodent species is highly selective in its choice of plant food from the numerous species available, and the degree of competition with livestock varies. Through selective feeding, rodents may hold certain plant species in check and keep them relatively scarce in the composition. Increased populations of rodents may bring about the reduction, or even the elimination, of certain plant species preferred by them.

Burrowing animals, most notably the rodents, but also toads, worms, spiders, beetles, and ants, have important effects on the soils of the areas they occupy. They move enormous quantities of earth, mixing the different soil layers with each other, with plant material, and with their own dead bodies and excrement. Changes in porosity, in susceptibility to erosion, and in fertility of soil result; and probably general productivity is increased. Beneficial effects from this type of activity partly compensate for the damage done in destroying forage. The economic role of each species is thus determined by the sum total of its multiple effects.

Great changes from year to year occur in numbers of some animals, and their effect varies correspondingly. Amounts eaten and trampled each season may vary according to the total amount available as well as the population of rodents present. Hence rodent damage is not a constant factor, but changes greatly from year to year.

\section{THE WILDLIFE AND ITS INTERRELATIONS}

Life Zones and Habitats. - The fauna of the Range is fairly typical of the oak and digger pine association of the foothill belt of the Upper Sonoran Life Zone in which the area is located. From an ecologic standpoint, one of the most distinctive features of the region is the presence of granitic rock in extensive outcrops, or loose piles of large boulders (plate 2, lower). Always closely associated with the rock and apparently in some way dependent on it here, is the most abundant tree species of the region, interior live oak. Both the rocks and the live oaks have significance in controlling the occurrence and abundance of various wildlife species. Many species depend on the rocks either as a permanent home or as a place of refuge. Notable among these are the canyon wren, the rock mouse, the wood rat, the night snake, and the skink, all of which are common on the area. 
Many of the vertebrates, especially birds, are partly or wholly dependent on the oak woods as the essential part of their habitat. Among these are the California woodpecker, the plain titmouse, the phainopepla, the California jay, and the slender-billed nuthatch. Extensive areas of open grassland constitute the preferred habitat of such other species as the kangaroo rat, the white-footed mouse, the meadow lark, and the horned toad. The Range is near the lower limit of distribution of chaparral in the foothills, hence chaparral is scarce. Nevertheless, many of the wildlife species on the area are closely restricted to brush patches. Among these are the California thrasher, brown towhee, spotted towhee, Merriam chipmunk, and California racer.

Mammals of the Range.- The mammals of the region represent six main groups : the carnivores, represented by the coyote, gray fox (fig. $16, A$ ), bobcat, raccoon (fig. 16, $B$ ), badger, striped skunk, and weasel ; the rodents-kangaroo rats (fig. 17, $A$ ), ground squirrel (fig. 17, B), pocket gopher, and field mouse; the rabbits-blacktailed jack rabbit and cottontail; the bats-several species; the marsupials and insectivores each with a single species-the opossum and the mole respectively.

Birds of the Range.-The birds of the Range include, in addition to the resident species, some of which have been mentioned above, a greater number of migrants which regularly cross the area or settle in it temporarily in the course of their seasonal movements. Most abundant in this group are several kinds of sparrows, juncos, and other small species, but it also includes such waterfowl as the white pelican, great blue heron, white-fronted goose, and mallard. Many of the most conspicuous birds that breed on the Range, including the Arkansas kingbird, Bullock oriole, and mourning dove, are not present during the winter. The raptorial species include the red-tailed hawk (fig. 16, C), Cooper hawk, sparrow hawk, horned owl, barn owl, long-eared owl, and screech owl, all of which regularly nest on the area, and the golden eagle, bald eagle, roughlegged hawk, marsh hawk, sharp-shinned hawk, prairie falcon, and pigeon hawk, which occasionally occur on the area, but are not known to nest there. The road runner is a common resident on the Range.

Several wildlife species on the Range are classified as game and have economic importance in that connection. The California valley quail heads this list.

The mourning dove is common in this region in summer and fall, and is hunted locally almost to the same extent as the quail. Among the mammals, the gray squirrel and cottontail are commonly considered game, but neither is a satisfactory game animal, either on the Range, or in the state at large. The gray squirrel is scarce and the cottontail cannot be safely handled, because it is a carrier of tularemia. 


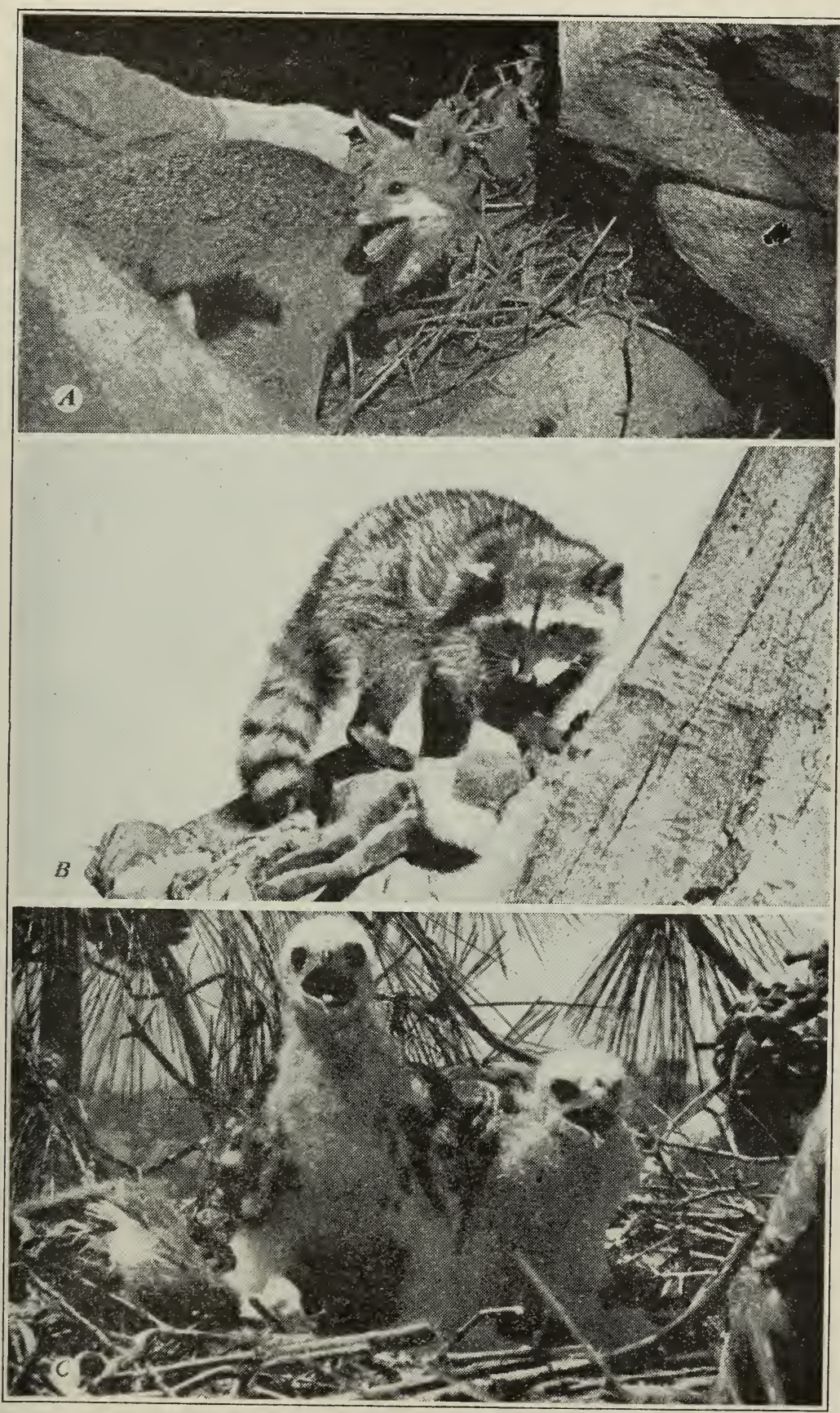

Fig. 16.- $A$, Gray fox. Rodents constitute part of his diet. $B$, Raccoon-an interesting carnivore. $C$, Young red-tailed hawks in their nest. Note the hind quarters of a ground squirrel at the left. 


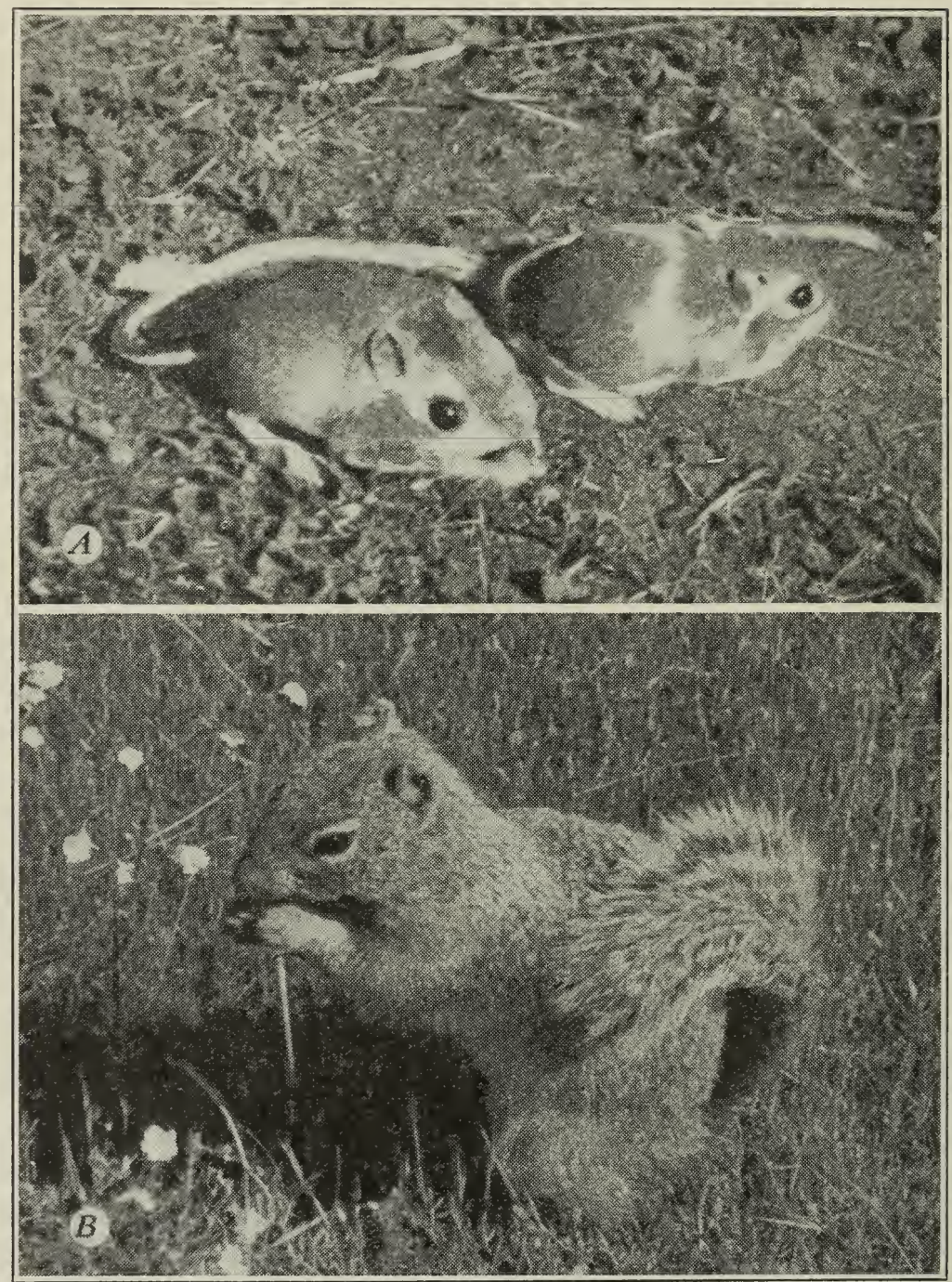

Fig. 17.-A, Kangaroo rats. These animals of nocturnal habit feed heavily upon the seeds and leaves of forage plants. $B$, Digger ground squirrel eating filaree.

Reptiles of the Range.-The reptiles, especially the lizards, are the most abundant vertebrates of the region. The Pacific rattlesnake is probably the commonest of the snakes, and, with a population of at least one to the acre, its numbers greatly exceed those of any other predator of wildlife in the region. The gopher snake, California racer, Boyle's king snake, and two species of garter snake are also moderately common, so 
that they play important roles as predators, and figure also as food sources to the bird and mammal predators.

Amphibians of the Range.-Because of the long dry season, and scarcity of yearlong water, amphibians are poorly represented, in number of species, on the Range. However, the California toad, spadefoot toad, and tree toad all are common. These species are limited in their season of activity above ground to the spring months when temperature is moderate and humidity is high. The remainder of their annual cycle is mostly spent underground, usually in rodent burrows. These species all are dependent on the short-lived, seasonal streams and pools for breeding places, and in dry years their reproduction is greatly reduced. In favorable seasons, the shallow pools of water everywhere are swarming with their tadpoles, which attract numerous predators, including the great blue heron.

Ecological Relations.-From the foregoing account it is evident that the ecology of the region is complex. Seasonal changes are marked. The mild, humid winter season produces an abundance of green herbaceous plants, but in late spring the vegetation suddenly dries out and dies. Through the long, dry season, extending over nearly half of the year, succulent vegetation is exceedingly scarce and many kinds of resident, plant-eating animals are forced to alter their feeding habits, and to subsist mainly on dry vegetation. The summer climate is severe, and distribution of shade and moisture become critical factors. In response to these conditions, populations of some species make seasonal movements off the area to distant regions; those of others become less active or entirely dormant for part of the year, while some change their habits, and may be either diurnal or nocturnal at certain seasons. Of the small vertebrates, rodents and lizards are by far the most numerous, and these two groups include most of the key species which mainly support the predator populations.

Lists of the Wildlife Species.-Of the wildlife species mentioned in this account, the kinds of birds are well-known by standardized vernacular names, but common names are less well established for some of the amphibians, reptiles, and mammals. To avoid any doubt as to the identity of the kinds referred to, the accepted scientific names of these animals are given below, listed in their classification order:

\section{Amphibians}

Spadefoot toad, Scaphiopus hammondii Tree toad, Hyla regilla California toad, Bufo boreas

\section{REPTILES}

Brown-shouldered lizard, Uta stansburi- Horned toad, Phrynosoma blainvillei ana

Fence lizard, Sceloporus occidentalis Whiptail, Cnemidophorus tesselatus Yosemite skink, Eumeces gilberti 
RePTILes-(Continued)

California racer, Coluber lateralis Gopher snake, Pituophia catenifer Boyle's king snake, Lampropeltis getulus
Garter snakes, Thamnophis sirtalis and ordinoides

Night snake, Leptodeira torquata

Pacific rattlesnake, Crotalus viridis

\section{BIRDS}

White pelican, Pelecanus erythrorhyn-
chos

Great blue heron, Ardea herodias

White-fronted goose, Anser albifrons

Mallard duck, Anas platyrhynchos

Sharp-shinned hawk, Accipiter velox

Cooper hawk, Accipiter cooperi

Red-tailed hawk, Buteo borealis

Rough-legged hawk, Buteo lagopus

Golden eagle, Aquila chrysaetos

Bald eagle, Haliaeetus leucocephalus

Marsh hawk, Circus hudsonius

Prairie falcon, Falco mexicanus

Pigeon hawk, Falco columbarius

Sparrow hawk, Falco sparverius

California quail, Lophortyx californica

Mourning dove, Zenaidura macroura

Road runner, Geococcyx californicus
Barn owl, Tyto alba

Screech owl, Otus asio (sp.)

Horned owl, Bubo virginianus

Long-eared owl, Asio wilsonianus

California woodpecker, Balanosphyra formicivora

Arkansas kingbird, Tyrannus verticalis

California jay, Aphelocoma californica

Plain titmouse, Baeolophus inornatus

Slender-billed nuthatch, Sitta carolinen. sis

California thrasher, Toxostoma redivivum

Phainopepla, Phainopepla nitens

Meadow lark, Sturnella neglecta

Bullock oriole, Icterus bullocki

Sacramento towhee, Pipilo maculatus

Brown towhee, Pipilo fuscus (sp.)

\section{MAMMALS}

Opossum, Didelphis virginiana

Mole, Scapanus latimanus

Weasel, Mustela xanthogenys

Striped skunk, Mephitis mephitis

Badger, Taxidea taxus

Gray fox, Urocyon cinereoargenteus

Coyote, Canis latrans

Bobcat, Lynx rufus

Digger ground squirrel, Citellus beecheyi

Merriam chipmunk, Eutamias merriami

Gray squirrel, Sciurus griseus

Pocket gopher, Thomomys bottae

Pocket mice, Perognathus inornatus and californicus
Kangaroo rat, Dipodomys heermanni

Harvest mouse, Reithrodontomys megalotis

White-footed mouse, Peromyscus maniculatus

Brush mouse, Peromyscus boylii

Rock mouse, Peromyscus truei

Wood rat, Neotoma fuscipes

Meadow mouse, Microtus californicus

Black-tailed jack rabbit, Lepus californicus

Cottontail, Sylvilagus auduboni

\section{RODENTS AND RABBITS OF THE RANGE}

Rodents and their near relatives, the rabbits, as a group, are herbivorous, and, therefore, on the range lands used primarily for livestock grazing, their effect is mainly deleterious in using forage that would otherwise be available to stock. Many species of rodents occur on the Range, and each differs greatly in the amount and specificity of damage. For most of the species, the economic bearing is either negligible or of 
minor importance, and three or four kinds are responsible for nearly all of the rodent damage.

The extent of damage depends mainly on the size, abundance, and food preferences of the species concerned. From the following account it will be seen that this problem is exceedingly complex, involving a knowledge of not only the amount and kind of food taken by an individual during a day, but also of the amount destroyed through burrowing and trampling, or by cutting wastefully, and the extent to which the foods taken are of kinds available or palatable to stock. To make any appraisal of rodent damage it is necessary to know accurately the population of a species and how it changes during its annual cycle, its seasonal changes in food preferences, and the extent of increase or diminution in its activity at different times of year. The amount and kind of vegetation present is an important factor determining the amount used by a given population of rodents, and may even be a factor in governing the numbers of rodents present.

The following discussion of the rodents and rabbits recorded on the Range is intended to show the abundance and economic importance of each. The four species which have the most important effect on the forage are the ground squirrel, pocket gopher, kangaroo rat, and cottontail; these species were, therefore, selected for intensive study. The ground squirrel probably ranks first on the list as a forage destroyer, and also is important as a reservoir of the diseases, tularemia and sylvatic ${ }^{\circ}$ plague, transmissible to humans. The pocket gopher was probably the most abundant range rodent in 1938 and 1939; it subsists partly on valuable forage plants, especially in winter, but it is also important as a cultivator of the soil. The kangaroo rat is generally abundant, but subject to violent fluctuations in numbers. The cottontail occurred in a population of one to the acre in 1939 and is an important competitor of stock for the forage crop.

Eleven other species occurring on the Range are relatively unimportant because of scarcity or specialized feeding habits which do not compete seriously with livestock. The combined effect of all of them, however, may be greater than it appears. The Merriam chipmunk is scarce and usually found in brushy ravines, where it depends largely on shrubby plants for food. The gray squirrel is likewise scarce. It usually stays in or near digger pines and lives on the pine seeds. The San Joaquin pocket mouse, present in a population of at least one to the acre in 1939, is a small species which subsists mainly upon minute seeds. The California pocket mouse is rare. The harvest mouse is even less

\footnotetext{
"The term, "sylvatic" plague is used here to designate what has heretofore been
} known as "bubonic" plague in native rodents. 
numerous, and is restricted to the larger swales which retain moisture through the dry season. The white-footed mouse is one of the commoner rodents, and was present in a population of at least one to the acre in the summer of 1939 ; it occurs mainly in open grassland. The brush mouse and the rock mouse are both common where there are rocks and brush thickets; populations were computed at several to the acre for both in the summer of 1939. The wood rat is partial to situations where there are large rock outcrops, brush thickets, or live oaks, where it may occur in a population of several to the acre, but it tends to avoid open grassland. Because it feeds mainly on leaves of shrubs and inner bark of twigs from oak and chaparral, it is unimportant as a forage destroyer but may compete with livestock for browse. The meadow mouse is scarce and confined to a small portion of the Range, the larger swale bottoms with permanent covering of thick vegetation, where the ground remains moist through the summer. The jack rabbit is rare on the Range.

In the rodent study that follows special attention has been given to the feeding habits of the important species, and detailed observations on feeding have been carried out at all seasons. Live-trapping and marking of entire populations has been attempted as a means of determining population densities and of obtaining information regarding the movements, seasonal and long-time fluctuations in numbers, longevity, and seasonal activity of the species concerned. All these phases of ecology must of course be solved for each species to attain any accurate economic appraisal of it. Some phases of these studies are still in their early stages, but in others considerable progress has been made, and the results to date are set forth briefly in the following account under the headings of the species concerned.

Ground Squirrel.-The digger ground squirrel is the most conspicuous rodent of the Range, because of its large size, abundance, and diurnal habits (fig. $17 \mathrm{~B}$ ). This ground squirrel has a bushy tail which makes up more than a third of the total length, well-developed and conspicuously erect ears, well-developed limbs fitting it for either digging, climbing, or running, and a brindled color pattern produced by alternate dark and light bars on each hair. The underside is paler, and there is a whitish patch in the shoulder region. The head is darker than the body, and the eye is conspicuously rimmed with white. A large adult is about 18 inches long. Adults weigh between 1 and 2 pounds, varying according to sex, age, and condition. The squirrel has highly distensible internal cheek pouches and often carries food by pouching it in the side of the mouth. Seeds and acorns are often carried to favorite feeding places in these pouches before being eaten, or to caches where they are stored for future use. 
In their foraging, ground squirrels are influenced by a complex of factors, including temperature, humidity, shade, location of preferred food sources, predators, and presence of other squirrels.

With the start of fall rains green food becomes available and the squirrels feed upon it extensively; broad-leaf filaree, brome, and fescue grasses are the staples of diet. During the early stages of growth, entire plants are taken. Later in the season as the plants mature, the tender leaves, and fruits are selected. During the spring, large quantities of the immature fruits of filaree are consumed, and after the seeds ripen these are extensively used as food.

As the season advances, the vegetation quickly dries out and dies. The squirrels turn to seeds, to acorns, and the summer-growing tarweeds. During this period of seed production the squirrels gather large quantities of seed. Some caching of food for future use is done. Table 16 gives a list of seasonal foods of these squirrels.

The heaviest toll on the forage occurs in the spring when the population is fully active and the young squirrels are out, for it is during this period that the squirrels are at their highest numbers. Later, some of the older squirrels become dormant, and many of the young have died or have been caught by predators.

Marked differences were noted in the feeding of squirrels in the 1938 and 1939 seasons owing to the differing availability of the food sources on the Range in these two years. These differences were mainly the result of the heavier rainfall and later growing season in 1938. The summer of 1939 was much less favorable. During this season the crop of catchfly was poor, loosestrife dried out early, and the yellow tarweed crop was only a small percentage of that produced in 1938. The crop of live oak acorns also was short. These foods, especially the live oak acorns and tarweed, had mainly supported the squirrels through the summer of 1938. There was, however, a heavy crop of blue oak acorns in 1939, and the squirrels depended on these almost entirely for food throughout the dry season. During this period adults lost weight and even half-grown young failed to gain all summer, which suggested that acorns as a steady diet are nutritionally deficient in some respect.

Permanently occupied squirrel burrow systems are of the colonial type having from 10 to 50 open holes. Frequently such burrow systems are each occupied by a single squirrel; more often two or three squirrels simultaneously inhabit the same system. When the population is at its maximum, large and favorably situated burrow systems may harbor ten or more squirrels. On the Range, where the squirrel population is not subjected to control by man, the number of burrows varies but little from year to year and is relatively stable compared with the actual number 
TABLE 16

Seasonal Feeding of the Digger Ground Squirrel

\begin{tabular}{|c|c|c|c|}
\hline Month & Principal food sources & $\begin{array}{l}\text { Other staple food sources } \\
\text { regularly taken where } \\
\text { available }\end{array}$ & Food sources occasionally used \\
\hline January & Broad-leaf filaree (leaves) & $\begin{array}{l}\text { Leaves of popcorn flower, } \\
\text { brome, common foxtail, } \\
\text { and red maids }\end{array}$ & $\begin{array}{l}\text { Leaves of fescue and buckthorn } \\
\text { weed; Mariposa manzanita } \\
\text { (flowers); acorns; puffballs; toad- } \\
\text { stools }\end{array}$ \\
\hline February & Broad-leaf filaree (leaves) & $\begin{array}{l}\text { Leaves of red maids and } \\
\text { popcorn flower }\end{array}$ & $\begin{array}{l}\text { Leaves of fescue, common foxtail, } \\
\text { brome, tarweed, ground lupine, } \\
\text { common chickweed, hairy lotus, } \\
\text { fine-leaf lotus, buckthorn weed, } \\
\text { locoweed, and baby blue-eyes; } \\
\text { acorns; Mariposa manzanita } \\
\text { (flowers); toadstools }\end{array}$ \\
\hline March & $\begin{array}{l}\text { Filaree (fruits); ground } \\
\text { lupine (entire plants) }\end{array}$ & $\begin{array}{l}\text { Red maids (flowers, } \\
\text { stems, leaves); filaree } \\
\text { (seeds and leaves) }\end{array}$ & $\begin{array}{l}\text { Leaves of popcorn flower, baby } \\
\text { blue-eyes, and yellow tarweed; } \\
\text { acorn }\end{array}$ \\
\hline April & Broad-leaf filaree (seeds) & Popcorn flower (seeds) & $\begin{array}{l}\text { Ground lupine (fruits and entire } \\
\text { plants); phacelia (leaves); popcorn } \\
\text { flower (stems); clovers (leaves); } \\
\text { soft chess (seeds); blue dicks } \\
\text { (leaves); acorns; birds' eggs }\end{array}$ \\
\hline May & $\begin{array}{l}\text { Birdseye gilia (flowers); } \\
\text { yellow tarweed (flow- } \\
\text { ers); seeds of filaree and } \\
\text { ripgut grass }\end{array}$ & $\begin{array}{l}\text { Seeds of catchfly, slender } \\
\text { oat, and common fox- } \\
\text { tail; red-stem filaree } \\
\text { (seeds and fruits); clov- } \\
\text { ers (flowers, stems, } \\
\text { leaves); ground lupine } \\
\text { (seeds and flowers) }\end{array}$ & $\begin{array}{l}\text { Blue dick (leaves); puffballs; birds' } \\
\text { eggs }\end{array}$ \\
\hline June & $\begin{array}{l}\text { Seeds of Wright'starweed } \\
\text { and catchfly;yellow tar- } \\
\text { weed (leaves); loose- } \\
\text { strife (leaves, flowers, } \\
\text { stems) }\end{array}$ & $\begin{array}{l}\text { Seeds of common foxtail, } \\
\text { ripgut grass, and digger } \\
\text { pine; flowers of godetia } \\
\text { and clover; wedgeleaf } \\
\text { ceanothus (berries) }\end{array}$ & $\begin{array}{l}\text { Seeds of slender oat, Napa thistle, } \\
\text { buckthorn weed, navarretia, and } \\
\text { ripgut grass; leaves of hollyleaf } \\
\text { buckthorn and California ever- } \\
\text { lasting; Spanish clover (stems, } \\
\text { pods, leaves); birds' eggs }\end{array}$ \\
\hline July & $\begin{array}{l}\text { Yellow tarweed (leaves); } \\
\text { acorns }\end{array}$ & $\begin{array}{l}\text { Spanish clover (fruits); } \\
\text { loosestrife (leaves and } \\
\text { stems) }\end{array}$ & $\begin{array}{l}\text { Stems of Spanish clover, filaree, and } \\
\text { popcorn flower; navarretia (seeds); } \\
\text { eriogonum (flowers) }\end{array}$ \\
\hline August & Acorns & $\begin{array}{l}\text { Turkey-mullein (stami- } \\
\text { nate flowers); ripgut } \\
\text { grass (seeds) }\end{array}$ & Loosestrife (seeds) \\
\hline September & $\begin{array}{l}\text { Seeds of yellow tarweed } \\
\text { and turkey-mullein; } \\
\text { acorns }\end{array}$ & Ripgut grass (seeds) & Feces of squirrels and rabbits \\
\hline October & $\begin{array}{l}\text { Yellow tarweed (seeds); } \\
\text { acorns }\end{array}$ & $\begin{array}{l}\text { New grass (brome, fescue, } \\
\text { common foxtail) }\end{array}$ & Leaves of filaree and popcorn flower \\
\hline November & New grass; acorns & Red maids (leaves) & Leaves of filaree and popcorn flower \\
\hline December & $\begin{array}{l}\text { Leaves of brome, filaree, } \\
\text { and fescue; entire plants } \\
\text { of filaree }\end{array}$ & Popcorn flower (leaves) & $\begin{array}{l}\text { Leaves of slender oat, buckthorn } \\
\text { weed, and sage }\end{array}$ \\
\hline
\end{tabular}


of squirrels present. Elsewhere, a reduction of 50 per cent in squirrel population has been observed with but little disuse of holes or burrows.

The burrowing activities of these squirrels has a twofold effect upon the production of forage that might be available for cattle. The burrows are fairly extensive in size, being from 3 to 6 inches in diameter and from 50 to 200 feet in length. Enlarged nest and food-storage pockets bring the displacement of earth to over 20 cubic feet for some systems. This soil is brought to the surface where it is dumped on growing vegetation. Digging is continuous so that a certain supply of soil is deposited on the surface each year. Through this and other squirrel activities a certain ground area is kept bare of vegetation in the immediate vicinity of the burrow. It has been found in studies elsewhere that from one fifth to one third of the square area that just contains a burrow system was denuded of vegetation by squirrel action. Where the squirrel population is high, and burrows numerous, this activity takes a portion of the area out of production. Complete figures are not yet available for such denuded areas on the Range.

On the other hand, finely pulverized mineral soil, old nests, carcasses of dead squirrels and the bodies of other animals (mice, snakes, lizards, toads, and insects) that have died in the burrows, together with feces, hulls, and other plant material, are all admixed in the soil of the mounds. This results in high productivity of this soil, as indicated in the increased plant growth there. Vegetation on these mounds on areas no longer occupied by squirrels is more luxuriant, of greater density and height, and remains green for from one to two weeks longer than on adjacent undisturbed soil.

Elsewhere in California, it has been recorded that no increasing forage production at old burrows could be found three years after the squirrels had been removed. At burrow systems occupied during the current season, the vegetation is noticeably different from that on adjacent soil. Red-stem filaree is a highly characteristic plant of the burrow mounds, and may form a dense mat over several square yards within an area of burrow mounds, although it is scarce in the composition a few yards away in undisturbed soil. This filaree is a favorite squirrel food. Buckthorn weed also thrives on the edges of the burrow mounds.

In their annual feeding cycle, the squirrels dig out considerable quantities of food, including certain subterranean fungi, and roots of such plants as broad-leaf and red-stem filarees, common foxtail, and Bermuda grass. When digging for these, particularly in sandy soil, they may disturb the surface layer over extensive areas.

The total effect of squirrel burrowing upon soil and forage production is the subject of further study at other locations in California. 
While ground squirrels in this region are individually restricted to small foraging areas, there are occasional shifts of the home base, apparently correlated with changing availability of food supply, shade, and other factors. Such shifts are usually short, so that the squirrel remains within the same general area with which it is familiar; but occasionally much longer movements are made, taking the squirrel far beyond the limits of its original foraging range. It may be noted that there is little incentive for this type of movement on the Range where the whole country is relatively uniform and seasonal changes in availability of food are mainly between adjacent knolls and swales, or trees and open grassland. In areas providing contrasting habitats, for instance, places where range land is adjacent to cultivated crops, extensive movements from less to more favorable areas are much more general.

As stated before, evaluation of rodent pressure on the Range depends upon the total population of rodents present. In 1934, counts of 12 to 15 squirrels per acre were secured on the intensive study area of pasture 1, and on other favorable sites over the Range. Sick and dying squirrels were found on several occasions during the spring of 1938 and 1939. There has been a rather steady seasonal decline until it is estimated that there were not more than half as many squirrels on the Range in 1940 as in 1934. Such fluctuation plays an important part in the pressure of squirrels on a range.

In changes of populations on extensive areas, migration is probably a minor factor-far less important than reproduction or death. The breeding season is mainly within January and February, and only one litter is produced annually. The litters average about seven young each on the Range, and this litter size has been shown to be the average elsewhere over the geographic range of the species. Since females constitute about half the population in the breeding season, the squirrel population is increased within a few weeks to more than four times the January figure. Young usually first appear aboveground in late March or April, when they are several weeks old. From April, 1939, to February, 1940, the ratios of young to adults caught on an 80 -acre area indicate the abundance and ratio of young to adults to be constantly changing. In late June and July the young outnumbered adults more than four to one. During late summer, fall, and winter, however, the ratio of young gradually decreased until, in February, they comprised only two fifths of the population.

Other parts of the Range were censused by comparing number of squirrels seen per unit time with similar counts made on the trapping area where the population was known. The total population figure derived for the 1,400 acres of the six grazing-intensity pastures was 3,465 , 
or 2.49 squirrels to the acre. (See fig. 1.) These were distributed as follows :

\begin{tabular}{|c|c|c|}
\hline & $\begin{array}{l}\text { Total } \\
\text { squirrels }\end{array}$ & $\begin{array}{l}\text { Squirrels } \\
\text { per acre }\end{array}$ \\
\hline Pasture 1 (154 acres) & $\ldots 561$ & 3.6 \\
\hline - Pasture 2 (230 acres) & $\ldots 871$ & 3.8 \\
\hline$\checkmark$ Pasture 3 (155 acres) & $\ldots 629$ & 4.1 \\
\hline ¿ Pasture 4 (309 acres) & $\ldots 554$ & 1.8 \\
\hline Pasture 5 (250 acres) & $\ldots 341$ & 1.4 \\
\hline - Pasture 6 (316 acres) & $\ldots 509$ & 1.6 \\
\hline Natural area (150 acr & $\ldots 120$ & 0.8 \\
\hline
\end{tabular}

It will be noted that pastures 1,2 , and 3 are similar in density of squirrel population, and that pastures 4,5 , and 6 are similar though they do not support quite half so many squirrels as do pastures 1,2 , and 3. It cannot be stated definitely just why the condition exists, though several factors might contribute to it. Pastures 4 and 5 have more south exposure, with probably higher temperatures, and fewer oaks and swales, both of which may be essential to maintaining squirrels during the summer. Pasture 6 is lightly grazed, but has a slightly higher population than 5 which is moderately utilized.

There is no indication here that different intensities of grazing on this range are responsible for limiting or permitting an increase in squirrel population. While these grazing-intensity pastures are stocked at different rates, the degree of forage production, and utilization by livestock is not strictly in accordance with pasture size, as shown in the section on forage crop management. Pasture 2 was lightly grazed, and supported 3.8 squirrels to the acre. Pasture 6 also lightly grazed had only 1.6 squirrels per acre. Pastures 1 and 5 are similar in that both were moderately grazed and they supported 3.6 and 1.4 squirrels to the acre respectively. Pasture 4 is moderate to moderate-to-light in utilization, and has 1.8 squirrels to the acre. Pasture 3 , the closest utilized of all, has only 4.1 squirrels to the acre, and this is not noticeably greater than the 3.6 squirrels to the acre of pasture 2, which is lightly utilized. The natural area (fig. 1) has been ungrazed since 1935 . Old vegetation has piled up, and the population density of squirrels was only 0.8 to the acre. This area, however, has been badly disturbed by headquarters activities and is not truly representative of a totally unutilized area. The only deduction that can be made from these data is that complete nonuse of the area might set up a condition that would support only light populations of ground squirrels. No direct correlation is indicated by these data, between intensity of utilization and density of squirrel population. Factors other than grazing appear to be involved, and further study is being made of these influences. 
Kangaroo Rat.-Though seldom seen because of its nocturnal habits, the kangaroo rat is so distinctive in appearance that there is little chance of mistaking it for any other rodent (fig. 17, $A$ ). The neck is short, and the animal appears to be nearly all head, large hind legs (kangaroolike), and tail. The long, tufted, white-tipped tail; the broad, flat head with masklike facial markings; the long vibrissae (whiskers) ; the large, protruding eyes, powerful hind legs and small forelegs; and the external, fur-lined pouches, all serve to identify it. The coloration, as seen from above, is pale brown, while the underparts are pure white. Adults weigh between 2 and 3 ounces. In its ordinary movements the animal progresses in short hops using only the large hind legs. At any alarm the gait is changed to a series of long bounds. The forelegs, though small, are thick and muscular with long claws, and are well adapted for digging.

In choice of foods, kangaroo rats are more specialized than ground squirrels, pocket gophers, or cottontails. Kangaroo rats as a genus are noted for the habit of storing large quantities of food material in underground nests or caches, although in the species under discussion the storing habit seems little developed. No special underground chambers for storage of food were found in any of the burrows (more than 100) excavated. The ample supply of food on the Range throughout the year renders extensive storage unnecessary. During the late spring, large surface caches of soft chess seeds are occasionally dumped in piles at blind ends of surface runways, and the accumulation may amount to more than a quart. Much of this harvesting is done before the grass has fully dried out, and caching aboveground may serve to cure it. During the winter, when green vegetation is plentiful, the rats feed mainly upon it. The stomach content of 17 rats trapped during the winter averaged 1.2 grams of green material. The two heaviest stomachs each weighed $2 \frac{1}{2}$ grams, and seemed filled almost to capacity.

Among thousands of food samples collected in winter from burrows and cheek pouches, filaree leaves were by far the most frequent. Broadleaf filaree was taken more often than red-stem filaree. Green foliage material of many other annual plant species is utilized during the winter months, and availability seems to be an important factor in determining the kinds and relative amounts taken. Grass, including common foxtail, slender oat, and several kinds of brome, together with leaves of red maids and popcorn flower were found frequently in the small underground caches. In several instances accumulations of empty shells of pine nuts and acorns were found in winter burrows. These had been gathered in the summer or fall and no doubt utilized soon afterward. In the spring at the height of the growing season, filaree seeds are a favorite food. 
All data for the five or six months' period of the dry season indicate that the food consists almost entirely of seeds. Soft chess and filaree together make up most of the food taken. Common foxtail and fescues are also staple foods. Popcorn flower, species of red brome, lotus, ground lupine, and pine bluegrass make up minor parts of the diet. Probably the greatest kangaroo rat damage to forage is done during late spring, at the height of the growing season. At that time the animals are beginning to feed on the ripening grass heads, many of which are out of reach to them from the ground. Grass stalks are cut through near the base and mowed down by the rats. This cutting is done both to obtain food, and to clear away excess thick vegetation which would otherwise impede movements of the animals traveling along their runways.

Food in summer, as indicated by several hundred samples from cheekpouch examinations and from fragments mixed with the dirt of burrow mounds, consists of bromes, common foxtail, soft chess, fescues, and filaree. These made up all but a small portion of the cheek-pouch contents. Ripgut grass, Australian chess, clovers, and species of lotus were found in pouches occasionally.

Kangaroo rats are much less uniformly distributed on the Range than ground squirrels, and are most abundant in well-drained, open situations where vegetation is sparse. In general, they avoid the larger swales, and tend to be concentrated on ridges and knolls. The kangaroo rat population on the Range has been more subject to fluctuations than the squirrel population.

During the three months' period of October, November, and December of 1939, in trapping repeatedly over an 80-acre area in pasture 1 , the number of kangaroo rats caught were 397, or nearly 5 to the acre. Since this trapped area was somewhat more level and open with greater proportion of swale area than the Range as a whole, population density over the entire Range on the average considerably exceeded that of the trapping area. Thousands of recaptures of marked kangaroo rats indicate that these animals are in general rather localized in their movements. Many individuals were trapped time after time over periods of months, within a 50 -foot radius. A few, however, have been caught from onefourth mile to about a mile from the place where they were originally captured.

Litters of two to five young are produced by each female. Some females are in breeding condition at all times of the year, except December and January. So far as known only one litter is produced annually, but such a long breeding season indicates the possibility of more. In one instance a young of the year was known to have produced young the same season. In 1938, young of the year first appeared aboveground in May. In trap- 
ping operations carried on during June, they amounted to 53 per cent of the total catch. In July they increased to 67 per cent, then decreased and remained between 50 and 55 per cent through August, September, and October. The greatest numbers of young first emerge in July. In October there were still some young so small that they must have left the nest only a short time before; many others had grown nearly to adult size. Thus, in its annual cycle the kangaroo rat population reaches a peak in July, then gradually decreases to a low point (disregarding small young in the nest) in March or April.

Striking fluctuations in numbers of kangaroo rats from year to year on the Range have been apparent though no accurate measure of the change in numbers is as yet available for the entire area. In December, 1935, the rodent enclosures were treated with poisoned grain to remove all rodents after fences had been installed. On these areas, totaling 1.6 acres, an average of 30 dead rats were found to the acre. This number represents the minimum which could have been present, since from 25 per cent to 50 per cent of the rodents poisoned on an area die underground and are not found. Probably the kangaroo rat population in 1935 was at least 30 per acre on south-facing slopes and ridges of favorable habitat. In 1935 and 1936, kangaroo rats were remarkably abundant, and observers driving over the Range at night could see them in large numbers on the roads. Counts were made on measured distances of road while driving at a speed of 15 miles per hour, and as many as 75 rats to a mile were recorded. In the spring of 1937 the kangaroo rat population abruptly declined. In March, 1937, not more than 2 or 3 per mile were usually seen over stretches of road where as many as 75 per mile had been seen the preceding fall under similar conditions. By the spring of 1938, the population density was probably even lower. By the spring of 1940, the population had again made substantial increase and a maximum of 23 per mile were seen in night driving on the Range. In pasture 1 , in the fall of 1939, exhaustive live-trapping of the rats indicated a population density of 5 to the acre, and they were considerably more abundant on some other parts of the Range.

The causes of such fluctuations in numbers of this rat are as yet obscure. The sudden drop indicated disease to be a possibility and this is being investigated. The total effect of kangaroo rats on the range is greatly influenced by these large changes in numbers.

The burrows of the kangaroo rat are short and simple in arrangement as compared with those of pocket gophers and ground squirrels, and the rats are poor diggers, as compared with these mammals, or with other species of this genus. For 118 of their burrow systems excavated, the average maximum depth was 8.7 inches, and the average length of tunnel 
was 10.7 feet. There were, on the average, only 1.4 open holes to each burrow system. Of the burrows excavated, only 1 in 24 was occupied by a rat. This applies to a population about one sixth that on the area in 1934-35. Occupied burrow systems contained straw nests, and usually small amounts of cached food, while other burrows contained neither nests nor foods. Most of the burrows which had no occupants, nevertheless, appeared to be regularly used. Most of the burrows were no doubt occupied when the rats were at a peak in numbers in 1935-36.

The effect of kangaroo rats upon the soil is much less than that of the ground squirrel and pocket gopher. There is but a small amount of digging, and only a little vegetation is admixed with the soil. The cultivating effect is low, and such benefits from this kangaroo rat's activity are at a minimum.

Pocket Gopher.-The species of gopher which occurs on the Range is smaller than most representatives of the genus, and is peculiar to the digger pine belt of the foothills. The most conspicuous external features of the pocket gopher, distinguishing it from other small mammals, are the slitlike fur-lined cheek pouches, the very large front teeth, protruding even when the mouth is closed, the short, powerful front limbs with elongate claws, the small beady eyes set far apart on top of the head, the rather short, sparsely-haired tail, and the coloration-reddish brown above and grayish below.

Pocket gophers spend most of their lives underground, living in elaborate tunnels or runways, gathering their food at the ground surface, carrying it to their nests or storehouses, and eating it there at their will. The variety of plant materials found cached together underground indicate that during the early stages of growth the gophers exercise little choice in gathering food, but take whatever is conveniently available. Broad-leaf filaree is probably the most used food, and the plants are often taken entire, with leaves, stems, and roots intact, until they reach a size which makes them difficult to handle whole. Popcorn flower is much used. Cuttings from other kinds of plants found in the burrow systems included tomcat and white-tip clovers, common foxtail, fescue, soft chess, ripgut grass, red brome, poverty fescue, baby blue-eyes, buckthorn weed, and tarweeds. Such green material as this is dumped in loose piles at points along the tunnels or in the nest cavity and is used soon afterward. In winter and spring, green leaf and stem material make up most of the food, and gophers do most of their foraging on the surface of the ground. A large portion of the gophers' food consists of stored material which is gathered at the season when it is available and cached underground for use when food is less plentiful. For this purpose, special flask-shaped chambers usually much smaller than the nest chamber are constructed 
and connected by short tunnels with the main runways in either the shallow or the deep portion of the burrow system. Acorns of either blue oak or interior live oak, according to availability, constitute the most important source of food for storage. In the winter, after acorns have disappeared from the surface of the ground, quantities may be found in gopher burrows, and often the ground under oak trees is honeycombed with holes, indicating unusual activity at such places. Bulbs of blue dicks and perhaps those of other liliaceous plants also are stored in quantity and may be of as much importance as acorns in providing a food source. Occasionally, digger pine seeds are found cached in burrows.

During the dry season roots of tarweed are eaten, probably, because they provide some degree of succulence when most other vegetation has dried out.

Only a limited amount of work has been given to population studies of gophers on this range. In 1938 and 1939, the population in pasture 1 censused late in the breeding season by counting actively used burrow systems amounted to from 5 to 8 to the acre. In May, 1940, after most young of the year had left the nests, a 4 -acre area in the west end of pasture 1 was trapped out and it yielded 25 gophers to the acre. This area was fairly typical of the Range as a whole in abundance of gopher mounds.

Gophers construct complex burrow systems. Each system consisted of a maze of tunnels which may have a total length of several hundred feet. Tunneling is at a fairly uniform depth of 6 or 8 inches below the soil surface and also includes a deep portion, from 1 to 5 feet below the surface, ordinarily not more than a few yards long, and which leads to a globular nest chamber filled with dry, shredded grass leaves and stems.

On the Range the pocket gopher does much more burrowing than all other rodent species together, and is, therefore, more important as a cultivator of the soil. During that portion of the year when the soil is moist enough to be workable, gophers are continually extending their burrow systems, and usually throw up one or more new mounds daily. Seasonal movement is directed by varying food supply and soil moisture. During wet weather of the winter and spring months, swales are uninhabitable and gophers then work on the higher ground. In the late spring and early summer, gophers move downhill into the green swales and do most of their feeding there when the vegetation has dried out elsewhere. By the time the swales have dried out they may be honeycombed with burrows, and much of the ground surface may have been covered with loose earth of the mounds. Much vegetation is covered over, and no new growth appears on the mounds until the following year.

During the course of the year large quantities of soil are moved. Dur- 
ing the wet season excavated soil is thrown out upon the surface of the ground where it covers vegetation, and is admixed with it. During the dry season when temperatures of the upper soils are high, the gophers dig deeper, the excavated earth from these lower levels being placed in the shallow surface runways instead of being thrown out aboveground. Large quantities of chopped and shredded vegetation is mixed through all this material. Cattle break into the shallow surface runways, and the gophers repair the breaks. The net result is constant cultivation with the admixing of organic matter with the granitic soil. While final conclusions cannot yet be drawn, it should be stated that such cultivating and fertilizing effect on this range may result in increased forage production to offset the forage eaten and destroyed by the gophers.

Cottontail.-The cottontail is a typical rabbit and is so familiar that it needs no special description.

Abundant shelter, such as brush, rock piles, or thickets of tall vegetation interspersed with grassy places, furnish favorable cottontail habitat. The Range permits these conditions, though in varying degree in different parts of the area. On the natural area, where vegetation remains unused to afford thick cover, and a continuous water supply is available, cottontails are more abundant than on other parts of the Range. It was not uncommon in the summer of 1939 to see from 10 to 40 on the lawn about headquarters at dusk.

Cottontails were relatively scarce on the Range in 1934, but no data are available concerning their abundance previous to that time. There was evidence of a gradual progressive increase until 1938, and during 1939 and early 1940 their numbers remained fairly stable except for seasonal fluctuations. During the summer of 1940 the numbers dropped to less than half of the 1939 summer populations, most of this reduction occurring over a 6-weeks' period. Extensive live trapping on 80 acres during the summer of 1939 yielded about one cottontail to the acre. Probably most parts of the Range are better suited for cottontails than this trapped area and the figure is conservative.

Breeding is limited to the late winter and early spring, the young being well grown before the forage crop has dried out. The seasonal peak of cottontail abundance occurs at a time when forage is maturing and most heavily used by livestock.

Cottontails use many kinds of vegetation for food and are much less discriminate in their feeding than are most of the rodents. Being voracious eaters they compete directly with stock for forage, although the data accumulated thus far are too fragmentary to afford the basis for a complete account of their annual feeding cycle. During winter and early spring these rabbits feed on green vegetation, and probably take 
whatever is most readily available, so that filaree and the commoner grasses make up a major portion of the diet. After the beginning of the dry season, swales where succulent vegetation persists longer are favorite feeding places. Clover is much used and later such plants as dock, rush, and tarweed, and even turkey-mullein, which remain green into the summer, are selected, apparently as a source of succulence. In feeding on large plants of this type, the foraging rabbit cuts the stem near the base, and then eats outward toward the tip. Often a large portion of the cut top is discarded. Heads of soft chess and tarweed plants comprise an important food source throughout the dry season. Cast seeds of fescues are often grazed upon by the rabbits during the summer, when the seeds form a dense mat over the ground in places where these grasses are abundant.

\section{FACTORS INFLUENCING RODENT AND RABBIT ABUNDANCE}

To evaluate changes in rodent pressure on the range resulting from the marked changes in populations which are apparent, investigations have been initiated into the causes and frequency of the fluctuations. Important factors which influence rodent numbers include: changes in climate, extremes of weather, the scarcity or abundance of food, water, shelter, predators, parasites, and disease. Some of these factors have been studied in detail, others more limitedly. Fluctuations of course result from the interaction of all these factors, and caution must be exercised in drawing any conclusions from the limited data so far available. It is hoped that with the completion of studies now in progress the causes and importance of fluctuations in populations of range rodents will be better revealed.

Rodents serve as food for a number of carnivorous mammals. The coyote, gray fox, bobcat, and badger are fairly common, but no conclusive data are as yet available regarding their abundance or the extent to which they prey upon rodents. The striped skunk is too scarce to be a serious factor. Red-tailed hawks and horned owls are the most important raptors, while the golden eagle, rough-legged hawk, prairie falcon, and marsh hawk are unimportant, because of their scarcity or their preference for other prey. The rattlesnake is the most important reptile, while gopher snakes and king snakes play a lesser part.

Systematic collecting and analysis of "scats" (droppings) of carnivores and the pellets of raptors affords data on the food of these predators. Positive identification of some scats presents a major problem and where doubt existed the data were discarded from the tabulation by species.

In analyzing these materials, hair, bones, feathers, scales of reptiles 
and hard parts of insects remain, and may be identified. Such analysis is in terms of occurrence of the item in each scat or pellet and not on the basis of volume or weight.

Predation by Coyotes.-Of carnivorous mammals on the Range the coyote is probably the most important in its effect on rodents. Coyotes are subject to control on the area. About thirty were trapped in each of the winters of 1937-38 and 1938-39; in the winter of 1939-40, thirteen were caught. The annual catch undoubtedly has amounted to a large portion of the total population on the area, and it is the general

TABLE 17

Food Itrems Identified in Coyote Scats

\begin{tabular}{|c|c|c|c|c|}
\hline & \multicolumn{2}{|c|}{1939} & \multicolumn{2}{|c|}{1940 (to May 11) } \\
\hline & Number & Per cent & Number & Per cent \\
\hline lnsects. . & 102 & 7.2 & 34 & 8.6 \\
\hline Birds.... & 28 & 1.9 & 9 & 2.3 \\
\hline Reptiles.... & 83 & 5.8 & 14 & 3.5 \\
\hline Rodent and rabbit.. & 1,185 & 83.3 & 336 & 84.8 \\
\hline Miscellaneous...... & 25 & 1.8 & 3 & 0.8 \\
\hline Total food items... & 1,423 & $\ldots$ & 396 & $\ldots$ \\
\hline Scats analyzed..... & 794 & $\ldots$ & 219 & $\ldots$ \\
\hline
\end{tabular}

impression of persons familiar with the Range before control was applied that coyotes are now held far below their former numbers. Probably the population originally amounted to at least one to a hundred acres before control measures were taken. Control is carried out in late fall and winter and the coyotes are present in lowest numbers in early spring. From table 17 it is evident that rodents and rabbits make up most of the food. Ground squirrels were represented in the scats more fre- 7 quently than were any other prey species. The trend of feeding in 1939 and in 1940 is remarkably similar, though the 1940 data are incomplete. It is of interest that in this particular habitat the food is made up of relatively small animals, and rodents and rabbits together constitute more than four fifths of the food. The effect of coyote predation on rodent and rabbit populations of the Range is indeterminate with the data so far at hand, but it is a part of the combined impact of several common predator species directed simultaneously upon the same prey species.

It is of interest to note that the amount of effort expended on the Range in the control of coyotes has not eliminated them, nor has it been accompanied by an increase in squirrels and kangaroo rats. Rather, these rodents decreased during this period, as stated in an earlier para- 
graph, indicating that other factors than coyote predation play a major part.

Predation by Red-tailed Hawks.-Red-tailed hawks are year-round residents on the Range. During the winter of 1939-40, part of the Range, comprising an area of about 3,500 acres, was found to be occupied by 26 hawks, each restricted to a definite territory. In the spring of 1939 , $\int 71$ per cent of prey items brought to young in the nests by adult hawks, were ground squirrels; the remainder consisted of rabbits, pocket gophers, wood rats, kangaroo rats, mice, and several species of birds,

TABLE 18

Food Items Identified in Red-tailed Hawk Pellets

\begin{tabular}{|c|c|c|c|c|}
\hline & \multicolumn{2}{|c|}{1939} & \multicolumn{2}{|c|}{1940} \\
\hline & Number & Per cent & Number & Per cent \\
\hline Insects. & 84 & 9.4 & 31 & 6.7 \\
\hline Birds... & 29 & 3.3 & 11 & 2.4 \\
\hline 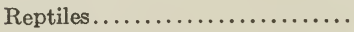 & 149 & 16.7 & 107 & 23.2 \\
\hline Rodents and rabbits............. & 629 & 70.6 & 312 & 67.7 \\
\hline Total items in pellets.. & 891 & $\cdots$ & 461 & $\cdots$ \\
\hline Pellets examined..... & 525 & ... & 266 & ... \\
\hline
\end{tabular}

snakes, and lizards. Squirrels were the preferred food. When the prey at a nest included both a squirrel and another animal, the latter was usually left uneaten and the young hawks fed from the squirrel exclusively. A study of feeding at times of year other than the nesting season, based on analysis of pellets picked up under territorial perches, revealed that squirrels continue to be the principal food throughout the year. From table 18 it will be seen that rodents and rabbits make up most of the food, but that insects, birds, and reptiles also are frequently eaten. In preying on rodent-eating snakes the hawks tend to partly offset the effect of their own predation on rodents. Analysis of 525 pellets shows that during the entire year of 1939, 70 per cent of the food of these hawks consisted of rodents and rabbits.

Predation by Horned Owls.-Horned owls occur at about 1 to each 80 acres on the Range, and their habits of feeding mainly at night give them some importance as predators on nocturnal rodents. Table 19 shows the occurrence of food items, from analysis of pellets for the years 1938, 1939, and 1940.

Rodents and rabbits constitute the major items of diet, and insects were second in importance. Of these rodents, wood rats comprised about 31 per cent; kangaroo rats, 23 per cent; pocket gophers, 15 per cent; 
ground squirrels, less than 5 per cent; and rabbits, 23 per cent. The wood rats and kangaroo rats are active at night, while rabbits and pocket gophers feed both day and night, and squirrels only during the daytime.

A study of horned owl nests (2) during the spring of 1939 shows that of the food brought to the nest to feed the young, all the 67 items were rodents and rabbits. Of these 23 (34 per cent) were wood rats (nearly all of them adults) ; 17 (25 per cent), kangaroo rats ; 13 (19 per cent), cottontails; 11 (16 per cent), ground squirrels; and 3 (5 per cent), pocket gophers.

\section{TABLE 19}

Food Items Identified in Horned Owl Pellets

\begin{tabular}{|c|c|c|c|c|c|c|}
\hline & \multicolumn{2}{|c|}{1938} & \multicolumn{2}{|c|}{1939} & \multicolumn{2}{|c|}{1940} \\
\hline & Number & Per cent & Number & Per cent & Number & Per cent \\
\hline Insects. . & 1 & 4.3 & 141 & 17.6 & 102 & 27.1 \\
\hline Birds... & 0 & 0.0 & 22 & 2.7 & 11 & 2.9 \\
\hline Reptiles............ & 0 & 0.0 & 32 & 4.0 & 5 & 1.4 \\
\hline Rodents and rabbits. & 22 & 95.7 & 606 & 75.6 & 258 & 68.6 \\
\hline Total food items in pellets..... & 23 & $\ldots$ & 801 & $\cdots$ & 376 & .. \\
\hline Pellets examined.. & 14 & $\ldots$ & 520 & $\ldots$ & 250 & $\ldots$ \\
\hline
\end{tabular}

Of all the animals on the area near the nests upon which owls could feed, pocket gophers and kangaroo rats were most abundant. Ground squirrels were less common; cottontails and wood rats were far less numerous. The relative abundance of wood rats in the nests and pellets indicated a definite selection by the owls. No birds of any kind were brought to the nests, and the pellets show only 2.7 per cent of birds, on the average. These data indicate that the horned owls are beneficial and that their pressure as predaceous birds is upon wood rats, cottontails, and kangaroo rats.

Predation by Rattlesnakes.-Over the three-year period from 1935 to 1937, all rattlesnakes found on the Range were killed in an attempt to exterminate them on the area. About an equal number were killed also in the 1938 and 1939 seasons and data were actually recorded for a total of 899 killed for the five-year period; perhaps as many more were killed for which no records were made. It became evident that despite this constant drain on the population, rattlesnakes were not becoming noticeably scarcer.

Past information together with preliminary work at the Range shows rodents to be an important article of diet of these snakes. Likewise, rattlesnakes are, numerically, the most abundant predator of rodents 
on the Range. Because of these facts, and the necessity of determining the function of predators in influencing the population of various rodents, it was essential that more complete understanding of the rattlesnake be gained. At the start of the 1938 season, these investigations were inaugurated on that part of the Range (pasture 1) set aside for wildlife research purposes.

On this intensive-study area all captured rattlesnakes were marked, released, and records made of recaptures. All captured snakes were caused to regurgitate their food; this added further to the data of prey taken. Except on this study area, snakes were killed when and where found, and their stomach contents examined. Such study seemed highly desirable because despite the abundance and widespread range of the Pacific rattlesnake, relatively little is known regarding it as a rodent predator. As the most numerous rodent predator it could have a pronounced effect on rodent populations, as well as its effect on livestock and other domestic animals. As a result of its bite, cattle occasionally die (see the section "Experimental Herd Management"), or at best suffer loss of weight, entailing a financial loss to the stockman. In the region of the Range there are no human fatalities from snake bite on record, and the only cases of persons being bitten have resulted from handling of the snakes. Nevertheless, the potential hazard involved in the presence of the snakes, and the resultant worry and inconvenience to humans must be taken into account.

For an evaluation of the effect of rattlesnakes on rodent populations, it is necessary to have a fairly accurate idea of the number present, their seasonal habits, frequency of feeding, and the species preyed upon with the relative numbers of each. If, at any time or place, it should be desirable to take control measures against a rattlesnake population, or exterminate them locally, knowledge of the population density, extent of normal movement and range of individuals, rate of population replacement by reinvasion and reproduction would all be essential to plan a control program more intelligently.

In the 1938 and 1939 seasons, and to June 30, 1940, a total of 515 rattlesnakes were caught alive on the Range, marked, and released after measurements, weight, and other data had been recorded for each. Subsequently, many of the marked snakes were again found and were caught or killed.

In the spring of 1939 the population on pasture 1 was computed to be 1 snake to the acre and in the spring of 1940 a figure of 1.3 was obtained. This computation was made on an area not especially favorable as habitat to the snakes and where large numbers had been killed in the preceding years. Therefore, it is probable that the population density for 
the Range as a whole was somewhat higher, and for the entire area of 4,700 acres a population of 5,000 rattlesnakes seems conservative.

Rattlesnakes are sluggish and inactive in their habits, but wander indefinitely with no apparent tendency ever to return to a given spot after once having left it. Time and extent of movement is exceedingly variable, but on the average the snakes move less than 10 feet a day, and may move only a few yards over periods of months.

Young rattlesnakes are born in the fall, and averaged 7.6 per litter in a small sampling. The population is probably more than doubled each fall by birth of the annual crop of young. The 300 or so killed annually on the Range and its vicinity by human intervention, make up only a small part of the annual increase. Hence, this must be only a minor cause of mortality which may have no significant effect on the population from year to year.

In a study of rattlesnake feeding during the 1938 and 1939 seasons it was found that nearly all the local species of rodents, cottontails, two kinds of birds, several kinds of lizards, and the spadefoot toad were all included in the diet; but the number of ground squirrels exceeded that of any other prey species, making up about one third of the total kinds of prey. The effectiveness of the rattlesnake as a ground squirrel predator is increased through its habit of occupying the burrow systems of the squirrels and striking any which come within reach. Frequently, dead squirrels showing symptoms of rattlesnake bite were found in the field. It is not known how often these snakes feed.

Presence of Diseases and Parasites. - The violent fluctuations in numbers of kangaroo rats, and the slower but certain change in numbers of ground squirrels, cottontails, and quail, together with the finding of sick animals, strongly indicated that disease and parasites are present in some of these wildlife populations. Reduction of kangaroo rats from not less than 30 per acre to only a small fraction of that number, over a period of less than two months, can more reasonably be ascribed to disease than to predation or habitat change. Some of the sick and dying ground squirrels found during the 1938 and 1939 rainy season were heavily parasitized and others displayed a pneumonic condition of the lungs. Examination of a large number of ground squirrels on the Range by the California Department of Public Health failed to show sylvatic plague to be present.

Sick rabbits have been found, but those examined did not show tularemia (rabbit fever), one of the diseases most commonly associated with rapid reductions of these animals.

Birds, as well as mammals are subjected to the attacks of parasites and the ravages of disease. Quail are known to have a blood-inhabiting pro- 
tozoan, but it is not known how these organisms affect numbers of quail. Glading (see the section "Studies on Valley Quail") found quail on the Range to be infested with this parasite. Possibly the disease reaches epidemic proportions under certain conditions, causing a reduction in the quail population. Young red-tailed hawks are attacked by parasitic flies (Eusimulium clarum) which in the 1940 season were an important cause of nest mortality.

The whole problem of disease and parasites as factors contributing to the regulation of numbers of wild creatures is a vital one. A number of prominent workers in this field have stated that disease and parasites are probably the most important factors in regulating the numbers of rapidbreeding animals when violent fluctuations do occur. Preliminary work on this phase has been done, and is being continued in an intensified study.

\section{EFFECT OF RODENTS ON VEGETATION IN THE ENCLOSURES}

The rodent enclosure installed on the Range in 1935 and 1936 was designed to give further information on the effect of ground squirrels, pocket gophers, and kangaroo rats, on the composition and density of the forage, and on the amount eaten and destroyed during a season by a definite number of each of these rodents. The initial installation consisted of a large rectangular pen divided into four compartments. One of these, comprising a half acre, was stocked with six ground squirrels; another, of one-quarter acre, was stocked with eight pocket gophers; one-quarter acre was kept as a control area with nothing using the vegetation, and one-quarter acre was stocked with eight kangaroo rats. This stocking was about equal to the maximum population densities known to have existed on the Range at the start of this experiment. A strip around the outside of the enclosures was fenced against livestock, but was accessible to all rodents and rabbits occurring in the vicinity. In addition to these enclosures, a series of fenced plots in the various pastures create areas completely protected from all rodents and livestock, and others exclude livestock but permit use by all rodents. (See the section "The Forage Crop and Its Management.") An original forage inventory and clip, prior to stocking the enclosures, affords the starting point on measures of production, composition, and density of forage.

It was inevitable that soil depth and fertility, areas of rock, slope, and tree shading varied somewhat in each one of the enclosures, and each one of these factors must have influenced the kind and amount of vegetation produced. The original location of the enclosures, however, was carefully selected on an area where the vegetation appeared as uniform in height, density, and general composition as it was possible to deter- 
mine, and where squirrels, kangaroo rats, and gophers already were present in normal abundance. After the first year of rodent use, differences in total quantities of some particular kinds of plants were easily seen. While these differences may have been brought about by a complex of factors, some of which are mentioned above, it seems obvious that the main difference in treatment of these areas is that of rodent use.

Each spring at the height of the growing season an "inventory" of the vegetation in the enclosures was taken by estimating the density and composition of the plants on 100 one-font-square sample quadrats selected by random sampling in each enclosure. Late in the fall, just prior to the start of rain, the quadrats on these plots were clipped, and the vegetation from them was air-dried and weighed to determine the forage residue after the annual crop had been subjected to a year of rodent use.

In the spring of 1939, a clipping and weighing of vegetation on 100 one-foot square plots was made in each enclosure, at the height of the growing season, to aid in interpreting the effect of rodents on forage yield.

These studies have pointed out needed changes in past methods of study of rodent pressure, and of the need of more intensive methods for these studies on annual-type ranges. It would be premature to draw hard and fast conclusions from present data, and further study now underway and contemplated during the next few years will, without doubt, alter at least some of the conclusions that could be reached now. With this caution it may be permissible to point out a few trends of this study.

In order to measure the effect of rodents upon the vegetation with precision, it would be necessary to measure the effects of all the other factors that affect forage production. It has, of course, been impossible to do all this, up to this time.

These rodent plots were placed in operation during the winter of 1935-36.

Wide fluctuations in the composition and density of plants occur in all of these plots from year to year, just as they do on the range as a whole. In some cases, still greater changes in certain forage species occur in the enclosure occupied by different rodents.

Tables 20, 21, and 22 set forth the percentage of forage plants in each enclosure that are the principal food of each rodent species in that enclosure. In the squirrel enclosure (table 20) the amount of broad-leaf filaree was consistently less for the years 1936 through 1939 than it was in either the control, the gopher, or the kangaroo rat enclosures. Filaree, in 1935, was more abundant in the squirrel plot than in the gopher plot, but less abundant by 4.94 per cent than in the control. During the period, 1936 through 1939, filaree averaged 13.83 per cent less than on the con- 


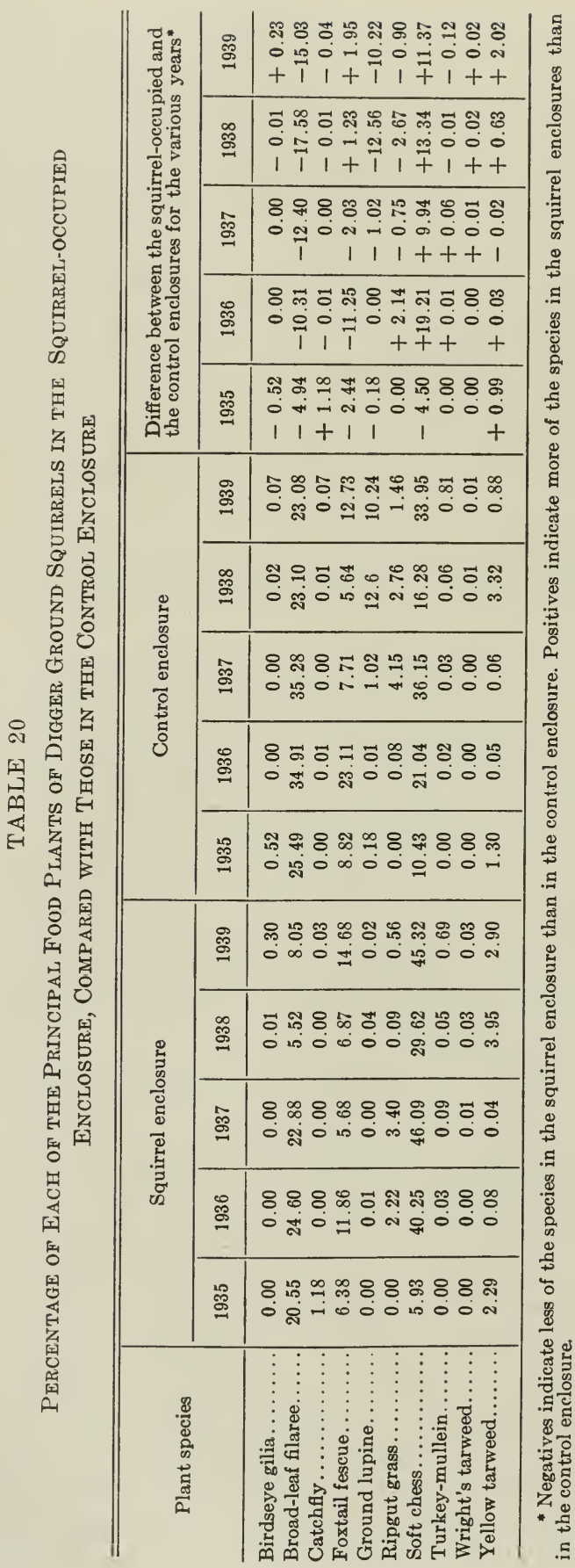


trol plot. Since filaree is one of the principal foods of ground squirrels, their feeding effect may be responsible for this difference.

Ground lupine, a choice squirrel food, is without doubt held down by squirrel pressure. Never abundant in the forage, it is avidly sought out by the squirrels; on the average it was only 3.0 per cent as abundant in the squirrel enclosure as in the control. Despite this fact, ground lupine does not show any progressive decrease in the squirrel enclosure; in fact it increased in 1938, but only slightly as compared with the control (0.04 per cent as against 12.6 per cent).

Soft chess also showed consistent change in the squirrel enclosure, and it increased rather than decreased in abundance. This common grass is eaten by the squirrels only during the early stages of growth in the fall months. Later in the growing season squirrel use of filaree and other rosette-type plants may favor growth of soft chess by thinning out these competing rosette-type species.

Other favorite squirrel foods, including ripgut grass, birdseye gilia, yellow tarweed, Wright's tarweed, catchfly (or campion), foxtail fescue, popcorn flower, red maids, and godetia, showed no consistent increase or decrease in percentages in the squirrel enclosure during the four-year period, but they showed marked fluctuations from year to year.

In the pocket gopher enclosure (table 21) filaree was consistently more abundant than on the control area despite the fact that during the growing season gophers take considerable quantities of this plant for food. Ripgut grass was consistently less abundant in the gopher enclosure; there was on the average only 20 per cent as much over the four years as occurred on the control plot. Yellow tarweed, soft chess, red brome, turkey-mullein, and all clovers varied from year to year, but there was no great difference in their relative abundance on the gopher plot and on the control.

In the kangaroo rat enclosure (table 22) broad-leaf filaree (even though it is one of the principal foods) was consistently more abundant than in the check enclosure. Filaree was more abundant in the rat enclosure in 1935 . Soft chess, the most used rat food, was 61 per cent, and ripgut grass was only 79 per cent, as abundant in the rat enclosure as in the control enclosure. Some of these differences probably are due to differences in the areas themselves and not to kangaroo rat activity.

Data from the dry clippings of the rodent enclosures indicate that the poundage of vegetation destroyed by a given population of rodents on a given area in a given time will vary greatly, the amount depending on the bulk of the forage crop, its composition, the feeding peculiarities of the rodent, and doubtless many other factors.

At the start of these enclosure studies in 1935 an inventory of forage 


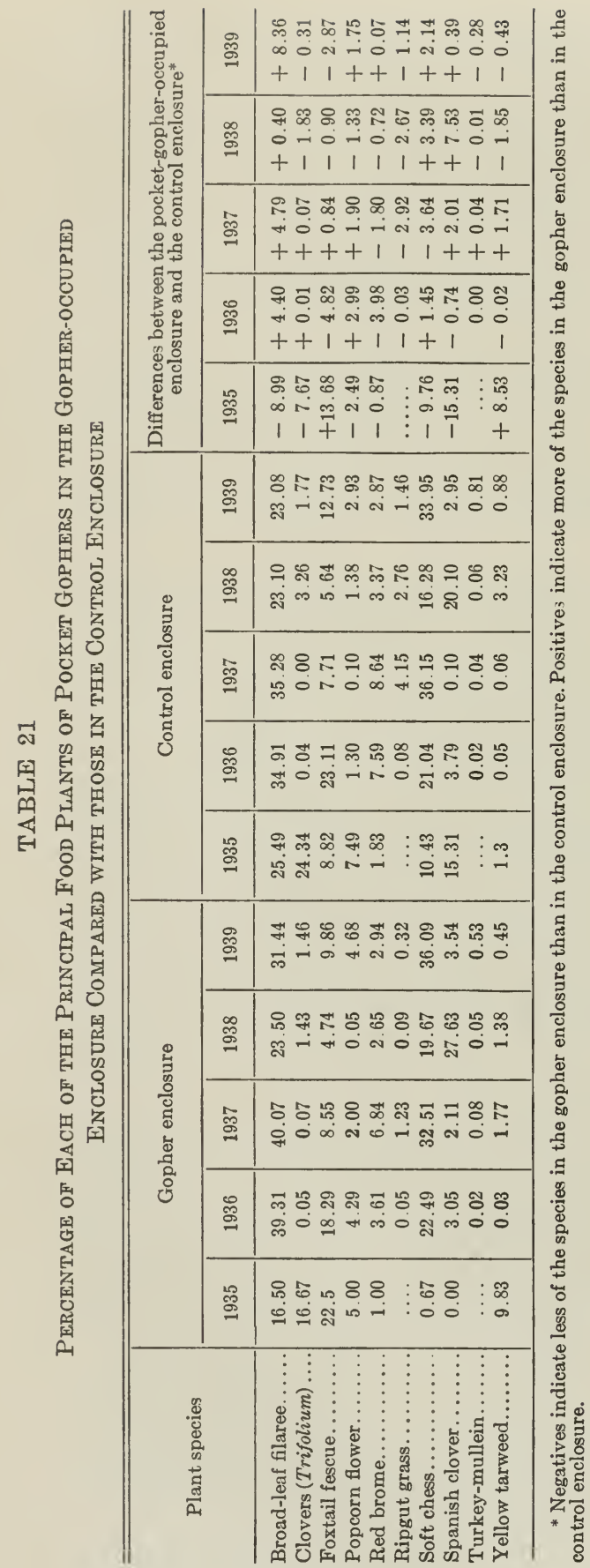

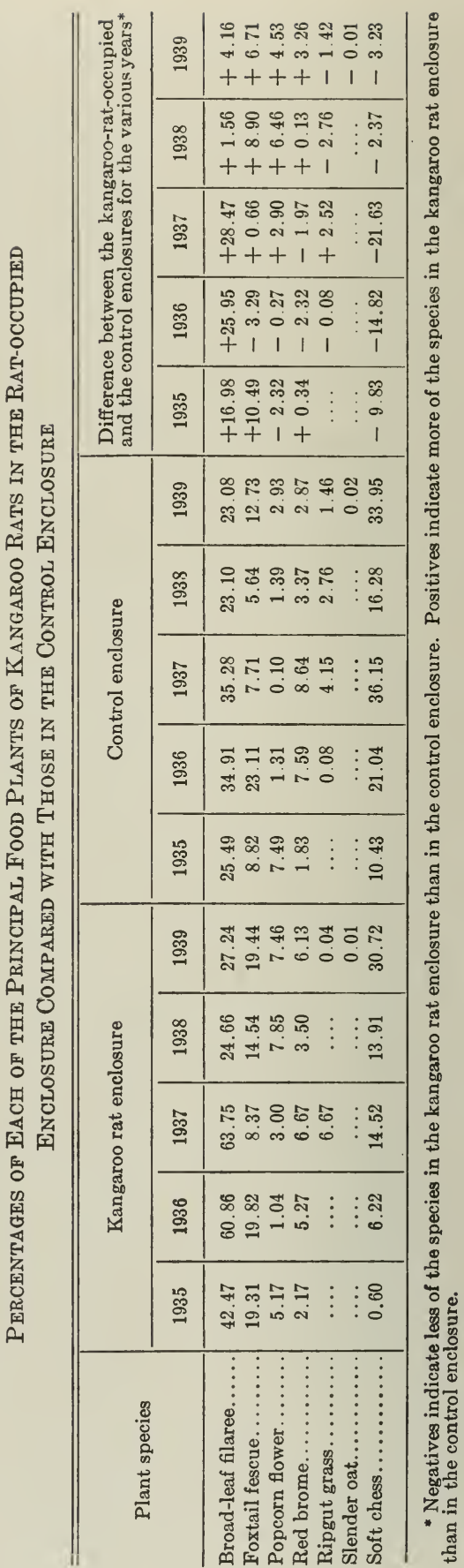


and a clipping and weighing of vegetation was made at the height of the growing season.

The forage produced by these plots in 1935 is as follows :

$\begin{aligned} & \begin{array}{l}\text { Pounds } \\ \text { per acre }\end{array}\end{aligned}$

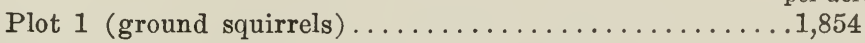

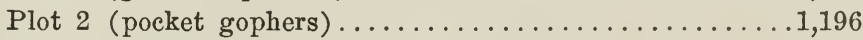

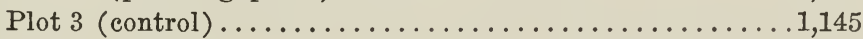

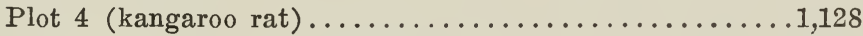

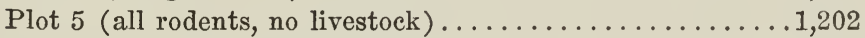

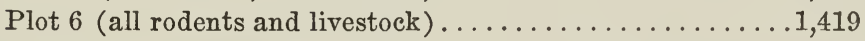

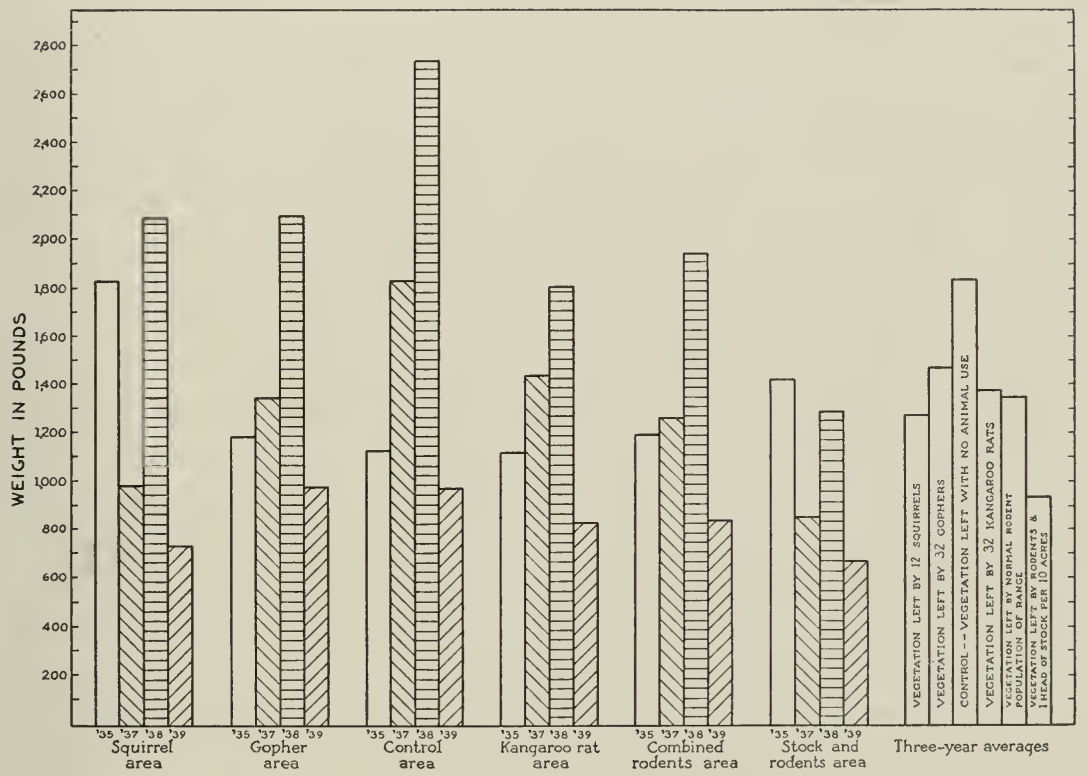

Fig. 18.- Pounds per acre of forage remaining in the fall on comparable areas subjected to use by different kinds of animals in 1937-1939. The data for 1935 are forage yield at the height of the growing season before the plots were stocked with the rodents.

These figures represent the forage produced with no usage, and clippings made at the height of the growing season. Analysis of these data show that only plot 1 (squirrel enclosure) was significantly different from plot 3 (the control plot). In all subsequent years, clippings were made at the close of the dry season, and figures represent residue after the rodents had been active all year. Plot 6 is somewhat different.

Figure 18 sets forth, graphically, the forage yield at the start of the experiment in 1935, and also the forage residue in each rodent enclosure at the close of the forage season, just prior to fall rain and the start of new growth. 
The seasonal fluctuation in forage production was discussed in detail in the section "The Forage Crop and Its Management." The data from the control enclosure of this table may be taken, therefore, as an approximation of the seasonal forage yield of these four plots. It portrays the trend, if not the actual poundage of each plot. On this basis it is evident that there is a wide annual difference between the forage produced and the forage residue on a plot that has been grazed by the same number of the same rodent species each year.

In 1938, the difference between forage produced in the control plot and residue left by eight kangaroo rats in the rat enclosure was more than six times this difference in 1939. The forage yield of the control and the kangaroo rat enclosures was about equal, showing that dissimilarity of the plots would not be the most logical contributing factor. Presumably the animals eat about the same amount from year to year, and the observed variation in poundage of residue and annual yield must result mainly from variation in the amount cut or trampled, but not actually eaten. The amount destroyed beyond the actual food requirement is probably somewhat proportional to the total amount available. Naturally, when there is a thick cover of vegetation, the rodents, in the course of their normal trampling and cutting, destroy a much larger amount than they would if the vegetation were extremely sparse. The poundage destroyed also might be expected to vary according to the kinds of plants being used. At certain times, in their foraging, rodents are destroying a much greater bulk of vegetation than they are actually eating. For instance, squirrels take filaree seeds by plucking off the entire fruits and discarding them after the fine seeds have been removed. After being dropped by the squirrel the fruit is no longer available to grazing stock, and its bulk is much greater than the minute seeds which are actually eaten by the squirrel. At other times squirrels are eating fine foliage material and all that is cut is actually consumed. Thus, the proportion destroyed but uneaten varies according to the particular item for which the rodent is foraging, and on the stage of development of the plants. The kind of items used depend partly on availability and therefore variation in the composition would in part determine the amount destroyed from year to year if the total bulk of the forage crop produced should remain constant.

It cannot be expected that the amount destroyed under a given rodent pressure will be exactly the same for any two years. For the three vears over which our records extend, and for the areas and plant compositions on which they are based, our figures are probably representative. However, to obtain an accurate figure for the average amount of vegetation destroyed under average conditions, it would be necessary to continue 
the records over a longer period of years, to be assured of statistically sound results.

It will be noted that the unused vegetation in the squirrel enclosure has been consistently lower than in the control plot, or than in any of the other rodent plots. At the start of the study the squirrel enclosure yielded one third more forage than the control, and more than any of the other plots. The indications here are that squirrels eat and destroy more forage than any of the other species of rodents studied.

In the gopher enclosure in the 1939 season, despite the activity of the animals, the amount of dry vegetation remaining at the end of the year was slightly greater than in the control enclosure. This suggested that the cultivating effect of the gophers on the soil might be sufficiently beneficial in stimulating plant growth to more than compensate for the actual destruction of vegetation by them. This seems especially true since each year's residue from the gopher enclosure is nearer to the residue of the control plot. Since gophers do much of their feeding underground, hardly any vegetation is trampled by them, and the underground portions of the plants used by gophers do not show up in the forage residue, and have little effect unless underground cutting kills the plants.

The discussion on unused forage, after a season of rodent use, serves also to show the need of further studies upon which to base conclusions of the amount of forage consumed or destroyed by each species of rodent. Briefly, the present data indicate that the forage consumed and destroyed by pocket gophers is largely compensated for by the increased production of forage brought about by their cultivating activities on the soils of this region. Caution should be used in assuming that a similar effect would be found on all soils in all other areas. Ground squirrels and kangaroo rats are detrimental; they without doubt took 15 per cent or more of the forage produced on these plots, under the conditions of these experiments. Additional data for analysis are needed before it can be said that a certain number of squirrels or kangaroo rats take enough vegetation to support a steer. 


\section{STUDIES ON VALLEY QUAIL}

T. I. Storer, F. P. CroNemiller, E. E. Horn, AND BEN GLADING

The California valley quail (Lophortyx californica vallicola) is the principal upland game bird of the Sierra Nevada foothills, and provides choice shooting for many sportsmen each hunting season. In early days quail were extremely abundant, often occuring in huge flocks. While still common, their numbers have been reduced by settlement, hunting, and other factors. Because of their value as game, there is an increasing interest in means for conserving and improving the crop of quail.

Since the major use of the foothill region is for grazing, the management of land there involves an adjustment between the needs for game and livestock. This relation will probably become of greater importance in the future, since proper management for quail may enable land holders to derive some additional income from the game crop. In turn, this makes a better understanding of the requirements for quail necessary, so that means may be taken toward increasing their numbers.

Association of upland game birds and livestock on public and private foothill ranges presents questions and problems of management. In an attempt to obtain necessary fundamental information for answers and solutions, a quail study on the San Joaquin Experimental Range was undertaken.

The Range is representative of the foothill range lands of California and is a particularly favorable site for studying the fundamental problems of quail biology, because (1) it is under strict control for research purposes, (2) the plant cover has been carefully mapped and annual inventories of the forage are available, (3) it is grazed by beef cattle and an accurate record of grazing intensity and other factors is at hand, and (4) studies are in progress on the biology and the relation of rodents and other wildlife.

In the autumn of 1936 the Coöperative Quail Study Committee was organized to plan and direct work on quail. The membership was drawn from several public agencies having special interests in the quail problem. ${ }^{7}$

The Committee has met with the biologist to plan the study, give tech-

${ }^{7}$ The Committee membership as of 1940 was as follows: E. I. Kotok, M. W. Talbot, J. W. Nelson, and H. H. Biswell, California Forest and Range Experiment Station; F. P. Cronemiller and I. Sack, U. S. Forest Service, Region 5; E. E. Horn and Henry Fitch, U. S. Fish and Wildlife Service; G. H. True, Jr., California Division of Fish and Game; J. T. Emlen, Jr. and T. I. Storer (chairman), Division of Zoölogy, University of California. Ben Glading was engaged as resident biologist to conduct the field studies, beginning in December, 1936. 
nical advice, review the findings, and aid in preparing publications that report the results of the study.

The studies to date have included a determination of the total annual quail populations on the Range; kinds of cover used by quail for escape, roosting, and nesting; sex and age ratios; seasonal changes in weight; seasonal program as to pairing, nesting, and flocking; history of pairs and their nests, eggs, and broods, together with causes of failure; enemies of nests, eggs, young, and adults; food throughout the year, especially in relation to kinds available; importance of drinking water through the dry season and means of providing it where needed; diseases, especially blood parasites; effect of man, livestock, rodents, and other animals on quail ; and experimental "harvest" of part of the quail crop by shooting on a portion of the Range, the hunter effort involved, and crippling losses.

Methods of Study.-To determine the factors influencing quail, it is necessary to learn the activities and behavior of flocks, pairs and individuals, to follow them through seasonal changes in the weather and the plant growth of the environment, to determine the annual cycle of nesting, and to find the effects of food, shelter, competitors, enemies, and disease. Since methods for the quantitative study of animals in their natural habitats are still in process of development, it has been necessary to try experimentally various means to obtain the data which are wanted regarding the quail.

Special traps have been designed to capture quail so that individuals may be marked with leg bands for subsequent identification in order to obtain weights, blood samples, and other periodic data. On each trapped bird was placed a numbered aluminum band and one or more colored celluloid bands for later sight identification. Nests were located and marked and the history of each followed to final success or failure. For over two years quail were collected on outlying portions of the Range or adjacent lands to provide stomachs for careful determination of the foods used. Observation blinds have been used at some nests and watering devices to study in detail the activities of individuals and small groups of quail.

Quail Census.-Each year a late winter count of the quail on the Range has been made by "horseback census," with three riders traveling in parallel courses back and forth over strips until all birds are enumerated. The method is practicable on open rolling range land with scattered cover. This type of census provides a determination of the population per acre and reveals the fluctuations which have occurred. The method and results have been reported elsewhere in detail (5). Counts of quail to date are given in table 23. 
Cover.-Valley quail require brush, rocks, or small trees as escape cover to avoid their enemies. Piles of cut brush plants are an adequate substitute where natural cover is scant. Small live oaks and certain of the larger shrubs are highly important as cover in which the quail roost. Destruction or removal of such growth on range lands results in a lessened quail population by reducing the "housing facilities" for the birds. Types of cover used by quail for nesting are listed in table 24 .

Sex and Age Ratios.-In 1939-40, a total of 703 birds were trapped (including repeats), from July to February inclusive. These included 254 individuals previously trapped and banded and 193 not previously

TABLE 23

Censuses of Valley Quail on the Range

\begin{tabular}{|c|c|c|c|c|}
\hline Year and dates of count & $\begin{array}{c}\text { Acres in } \\
\text { area of } \\
\text { count }\end{array}$ & $\begin{array}{l}\text { Number } \\
\text { of quail }\end{array}$ & $\begin{array}{c}\text { Birds } \\
\text { per acre }\end{array}$ & $\begin{array}{c}\text { Acres } \\
\text { per bird }\end{array}$ \\
\hline 1935, February 27. & 3,600 & $1,600^{*}$ & $0.44 \dagger$ & 2.3 \\
\hline 1936, February 27 to March 4. & 3,600 & 1,637 & .45 & 2.2 \\
\hline 1937, February 24 to March 2. & 3,600 & 2,123 & .59 & 1.7 \\
\hline 1938, March 9-17........... & 3,600 & 1,545 & 43 & 2.3 \\
\hline 1939, March $13-17 . . .$. & 3,412 & 1,293 & .38 & 2.6 \\
\hline 1940, March $6-10 \ldots$. & 3,412 & 873 & 0.26 & 3.8 \\
\hline
\end{tabular}

* Estimated.

$\dagger$ Based on sample strip count.

handled. The sex ratio was 103 males for each 100 females in the birds retrapped, and 105 for each 100 in the new birds. The age ratio naturally fluctuated, immatures of the current season being more numerous in early autumn. The older group showed 55 immatures per 100 adults and the newer 87 per 100 ; by February both groups contained about 63 immatures per 100 adults. Of birds banded in earlier years, there were 12 from 1936-37, 3 from 1937-38, and 46 from 1938-39. The oldest individuals handled were four to four and a half years of age.

Seasonal Changes in Weight.-Over 2,000 quail weights have been taken, 598 of these in the 1939-40 season. Records on young of the year show a gradual rise in weight from about 120 grams (4.2 ounces) in July to nearly 160 grams (5.6 ounces) in December. Adult males remain about the same from July to October, then increase sharply to over 170 grams (6 ounces) and decline but slightly until February. Adult females decline in weight until October, then follow the immature males as to increase. During the winter season there is an abundance of food, so there is no decline in weight by the local quail such as experienced by upland game in regions of severe cold winters.

Nesting.-During the four seasons, 1937-1940, a total of 289 nests were studied. Summaries of the results of these studies are given in 
tables 24 and 25 ; details of the results for 1937 have been published elsewhere (4).

Enemies of Quail.-Since many sportsmen believe that wild enemies are the major factor in reducing quail populations, particular effort has been made to determine the cause of losses. Some data on losses at times

TABLE 24

Principal Types of Cover USed by Quail for Nesting

\begin{tabular}{|c|c|c|c|c|}
\hline \multirow{2}{*}{ Cover type } & \multicolumn{4}{|c|}{ Percentages in the years given* } \\
\hline & 1937 & 1938 & 1939 & 1940 \\
\hline Dry grass or weeds, no other protection.. & 32.3 & 29.8 & 40.0 & 65.5 \\
\hline Fallen dead brush with grass or weeds $\ldots \ldots \ldots \ldots \ldots \ldots \ldots$ & 19.8 & 17.9 & 23.0 & 13.1 \\
\hline Rocks in dry situations; may have grass screens... & 13.5 & 16.4 & 10.7 & 11.5 \\
\hline Green swale vegetation: clover, rushes, etc.............. & 10.4 & 10.4 & 4.6 & $\ldots$ \\
\hline Late summer green vegetation: tarweed, turkey-mullein.... & 8.3 & 2.9 & $\ldots$ & $\ldots$ \\
\hline At base of deerweed.$\ldots \ldots \ldots \ldots \ldots \ldots \ldots \ldots \ldots \ldots \ldots \ldots \ldots \ldots$ & 6.2 & 1.5 & 4.6 & $\ldots$ \\
\hline 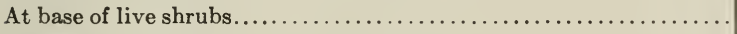 & 3.1 & 10.4 & 1.5 & 1.6 \\
\hline Scrap boards and other man-made debris............... & 2.1 & 2.9 & 6.1 & 1.6 \\
\hline On sides of eroded gully; banks or holes in banks................ & 1.0 & 1.5 & 4.6 & $\ldots$ \\
\hline 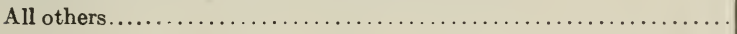 & 3.1 & 6.0 & 4.5 & 6.7 \\
\hline
\end{tabular}

- Based on numbers of nests as follows: 96 in 1937; 67 in 1938; 65 in 1939; and 61 in 1940.

TABLE 25

Summary of Nesting Data for Valley Quail at the Experimental Range

\begin{tabular}{|c|c|c|c|c|c|}
\hline Year and nesting period & $\begin{array}{l}\text { Total } \\
\text { nests } \\
\text { found }\end{array}$ & $\begin{array}{l}\text { Incubated } \\
\text { (at least } \\
\text { in part) }\end{array}$ & $\begin{array}{c}\text { Eggs per } \\
\text { nest } \\
\text { (average) }\end{array}$ & $\begin{array}{l}\text { Broods } \\
\text { hatched }\end{array}$ & $\begin{array}{c}\text { Young } \\
\text { per nest } \\
\text { (average) }\end{array}$ \\
\hline 1937 ; April 22 to July $26 .$. & 96 & 40 & 11.0 & 16 & 10.2 \\
\hline 1938 ; April 15 to July $28 .$. & 67 & 24 & 11.7 & 12 & 9.8 \\
\hline 1939 ; April 5 to July $5 . \ldots \ldots$ & 65 & 34 & 11.1 & 16 & 9.5 \\
\hline 1940 ; April 9 to July $22 \ldots$. & 61 & 35 & 12.9 & 15 & 9.5 \\
\hline
\end{tabular}

other than during the nesting season have been obtained, but these are still too few for reliable appraisal. Nesting losses can usually be indentified more accurately, although for some it is very difficult to determine the cause. The rather heavy losses in which there is no obvious disturbance of the nest have been ascribed to ground squirrels, but results obtained in 1940 suggest that a considerable percentage of these may be due to snakes. A summary of the record of nesting losses for 1937-1940 is given in table 26.

Food Taken by Quail.-Detailed analysis of the items taken by quail on the Range as food has been made for one year (6).

The food consisted of 99.5 per cent plant and 0.5 per cent animal material. The plant food consisted of 72 per cent seeds and 27.5 per cent leaves. 
Some plants such as Spanish clover and yellow tarweed were readily accepted as seeds and ignored as leaves; others, such as birdseye gilia and blue dicks, were highly acceptable as leaves and hardly ever taken as seeds.

Green plants, such as turkey-mullein, yellow tarweed, spurge, and Spanish clover, which were present in considerable amounts during the

TABLE 26

Losses in Nesting of Valley Quail

\begin{tabular}{|c|c|c|c|c|}
\hline \multirow{2}{*}{ Fate of nests } & \multicolumn{4}{|c|}{ Percentages for the years given* } \\
\hline & 1937 & 1938 & 1939 & 1940 \\
\hline Successful.. & 17.7 & 17.9 & 24.6 & 24.2 \\
\hline Abandoned before laying $t \ldots \ldots \ldots \ldots \ldots$ & 13.5 & 16.4 & 15.3 & $\ldots$ \\
\hline 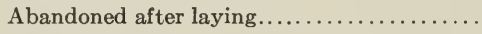 & 5.2 & 11.9 & 7.7 & 14.7 \\
\hline \multicolumn{5}{|l|}{ Robbed by: } \\
\hline Ground squirrel $\ldots \ldots \ldots \ldots \ldots \ldots \ldots$ & 31.2 & 26.8 & 30.7 & 16.4 \\
\hline House cat................. & 5.2 & 1.5 & 0.0 & 1.6 \\
\hline Coyote or $\operatorname{dog} \ldots \ldots \ldots \ldots \ldots \ldots \ldots$ & 5.2 & 7.4 & 6.1 & 1.6 \\
\hline Skunk....................... & 4.1 & 4.4 & 1.5 & 0.0 \\
\hline Bobcat................. & 2.1 & 0.0 & 0.0 & 0.0 \\
\hline 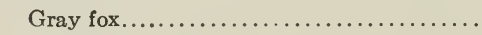 & 1.0 & 0.0 & 1.5 & 0.0 \\
\hline 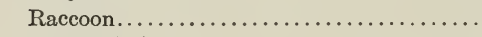 & 0.0 & 1.5 & 0.0 & 0.0 \\
\hline California jay................. & 2.1 & 1.5 & 0.0 & 3.3 \\
\hline Snake $f . . . \ldots \ldots \ldots \ldots \ldots \ldots \ldots$ & 0.0 & 4.4 & 6.1 & 9.8 \\
\hline Unknown predators.............. & 6.2 & 5.9 & 3.0 & 22.9 \\
\hline Trampled by cattle.............. & 3.1 & 0.0 & 1.5 & 0.0 \\
\hline Trampled by horse..$\ldots \ldots \ldots \ldots \ldots \ldots \ldots$ & 1.0 & 0.0 & 0.0 & 1.6 \\
\hline Accidentally destroyed by $\operatorname{man} . \ldots \ldots \ldots \ldots$ & 1.0 & 0.0 & 1.5 & 4.9 \\
\hline Robbed for experiment................ & 1.0 & 0.0 & 0.0 & 0.0 \\
\hline
\end{tabular}

* Based on same number of nests as in table 25.

+ Nests of this category not included in the 1940 count.

$\ddagger$ This was segregated in 1940 into gopher snake, 6.5 per cent, and king snake, 3.3 per cent.

dry summer, did not serve to any appreciable degree as sources of succulent vegetation in lieu of drinking water; the local birds depended chiefly on free water. Unpublished observations show that distribution of the birds in summer was definitely influenced by watering places.

A wide discrepancy was found between the relative amounts of certain items present in the plant cover and the proportions in which they were taken by the quail. Some species, though sparse in the plant cover, for example, clovers and ground lupine, made up a large percentage of the quail diet; whereas other common species, notably soft chess and foxtail chess, contributed only small percentages of quail food.

Ground litter samples were taken to determine the abundance of seeds available for quail food. It was revealed that there was a surprisingly large quantity of choice seeds remaining, even after quail had fed continually during the dry season; sample plots indicated that there was 
about 334 pounds of seed per acre on such areas in autumn before new growth of plants had started. This suggests that food alone may not be a very critical factor in the size of the quail population on the Range.

Drinking Water.-Location of available water has an important influence on the distribution of quail coveys. This is in agreement with other investigations on western dry ranges. Experiments are being conducted on the efficiency of various types of artificial watering devices at the Range. Information is being obtained on the amount of use other birds and mammals make of the same water supply, as also any interference by predators and range cattle. Eighteen water developments for quail have been established in dry locations on the range.

Disease.-About 500 blood smears have been taken from trapped birds and those collected for stomach analysis. Preliminary examination of some of these has shown that quail malaria is present, but detailed study of the material has not been completed. Additional studies are planned in an effort to ascertain the relation, if any, of disease to fluctuations in the general quail population.

Quail and Other Life.-Results of nesting losses show something of the relative importance of various animals, livestock, and man on the quail population. Additional data of other kinds are still too meager for analysis. General observation suggests that sizable quail populations may exist successfully on range lands devoted to other uses.

Experimental Hunting.-In wildlife management the ultimate objective is a harvest that can be placed on a sustained-yield basis. After numbers were determined, factors of environment analyzed, and life history studied, a regulated experimental hunt was arranged in 1938. A hunting management unit of 720 acres was established. A harvest of 26.5 per cent of the birds on the controlled area was accomplished by hunters selected by the Madera County Sportsmen's Association. A total of 136 quail was taken by 21 hunters, spending 96.8 hours of effort; or an average of 4.6 hours per man. The effort resulted in an average of 1.4 birds per man hour. It was continued on the same basis in 1939 and 1940.

Final conclusions and definite management recommendations must of course be based on further study, but the foregoing statements of progress illustrate the trend of results to date. 
OTHER STUDIES AND EXPERIMENTS IN THE PROGRAM OF THE SAN JOAQUIN EXPERIMENTAL RANGE

\author{
M. W. Talbot, H. H. Biswell, P. B. Rowe, and A. W. Sampson
}

The PReCeding sections have dealt in considerable detail with those studies of management of forage, cattle, and wildlife which have proceeded far enough to warrant progress-report statements. In addition, there are two studies which are not yet at publication stage and one which has been reported on in a separate paper. By including a brief description of the purpose, nature, and scope of these, it is believed that the reader may obtain a more complete picture of the whole program.

\title{
ARTIFICIAL RESEEDING
}

Stockmen throughout the granite area are becoming increasingly interested in range reseeding as a possible means of improving range forage. Increasing attention is being given to reseeding as an integral part of improved practices and systems of grazing. More and more they are asking such questions as : Can the present forage cover be improved through artificial seeding? How long will the new cover last, and what will be the cost? This is a very well-justified interest, because of the well-known deficiencies in the present foothill forage during nearly half of the year, from the time these annual plants dry to a crisp in May or June until fall rains bring green forage again in November or December. So, very logically the foothill operator asks : Can artificial reseeding help us bridge this gap of poor feed that is a source of great loss to the industry every year?

The question is complicated because of the practically rainless summer period of five months or more, which makes this problem more difficult of solution than in many other western range regions. Still, the values at stake are high, and the reseeding studies are widely regarded as an exceedingly important part of the investigations on this area.

The work has been planned as a three-step program. First, a study in the forage-plant nursery to test the adaptability of various species to the prevailing climate- on the better sites and with a minimum of competition from other plants. This comparison of many different kinds of plants growing side by side in weeded rows sorts out those that survive and grow best under the severe climatic conditions of this region. To date this trial has included some 225 species, including grasses, herbs, and shrubs-annual and perennial, native and foreign. Seeds for testing have been generously furnished by coöperators in the Bureau of Plant Industry, the Commonwealth of Australia, the Soil Conservation Service, and various other agencies. 
In the next step of this group of studies, the few plant species that show most promise in the nursery, in good soil, are seeded or transplanted to larger range plots, in more typical range soil, and also fenced against livestock and for a time against rabbits while the plants are becoming established. Thereafter, they are to be left alone to compete as best they can with the existing range vegetation. This second step will further sort out the comparatively few species that show promise in this test against both climate and competing vegetation. Approximately 50 different kinds of plants have been thus seeded or transplanted to date.

The third planned step, not yet undertaken, will consist of large-scale seeding on the range of those few species that best meet the first two tests; also the development of satisfactory methods of seeding.

This reseeding project has been limited largely to survival testing in the nursery plus preliminary testing on the range in competition plots. These tests are yielding needed information on behavior of the various plant species or strains under varying conditions of the rigorous foothill climate. In this area perennial grasses and herbs generally are at a disadvantage, for they are subjected almost every year to extreme drought conditions during the long hot dry summer period. Results to date of these incomplete studies do not yet justify recommending any plant species for extensive seeding on the range. Nevertheless, the promise shown by some, as briefly sketched in the following comments, warrants their further and wider testing.

Subterranean Clover.-Unlike our common bur-clover, the species Trifolium subterraneum produces burs both above and below the soil surface. The flower stems curve downward, which brings the flower clusters in contact with the soil. If the ground is moist and sufficiently soft, rootlike growths develop which draw the ripening fruit (the socalled "bur") into the soil-hence the common name, subterranean clover. There are many different strains, some of which are doing well at the Range. In 1939, some of the runners were 3 feet long and a heavy bur crop was produced. During the period 1938 to 1940, this plant reseeded itself well in the nursery where a good stand of volunteer plants appeared. Seed of this plant was obtained from Australia where it is regarded as an excellent forage plant.

Creeping-Rooted Alfalfa.-The species of Medicago, known as creeping-rooted alfalfa, has been tested for only one year, but the promise shown in this time warrants its mention. It was introduced from Turkey by the Bureau of Plant Industry from an area where the annual rainfall is about 12 inches and the elevation is 4,000 feet. This is a very deeprooted perennial which spreads rapidly by underground stems. Cuttings can be made readily. Seed is not yet available. 
Other Alfalfas.-About 25 different species of alfalfas have been received from the Bureau of Plant Industry for testing at the Range. Most of these are from India, Turkey, Chile, Manchuria, Afghanistan, China, Ecuador, Russia and Turkestan; two are native to dry areas of this country. Some of these alfalfas planted in the fall of 1939 are producing a heavy crop of seed. These are being tested in the hope that some may prove more drought-resistant than our common cultivated varieties and for that reason offer some possibilities locally in the more fertile range areas. Seeds of these plants are not yet available.

Bur-Clovers.-Several different kinds of bur-clover are included in the nursery tests. Some of these have reseeded naturally in the nursery and in other respects show promise, but their testing has not been carried far enough to show whether they are superior to the California burclover, which is an excellent range plant but has two weaknesses : spotted occurrence and uncertainty of yield. Some of these new bur-clovers produce very large burs, and if they should prove adapted to local conditions they would add to the value of the dry summer forage.

Garden Burnet.-This is another perennial plant that has survived the hot dry summers. It has reseeded itself in the plant nursery each year since 1936 and many new seedlings appear there every year. A planting was made in the competition plots out on the Range in 1937 and the plants have matured and produced seed every year.

Wimmera Rye Grass.-The species, Lolium rigidum var. strictum, grows, matures and produces seed in a short period of time. It is reported to be very palatable to livestock. During the two years of test in the nursery it has done well. Most of the seed crop was harvested but a scattered remnant produced many seedlings in the nursery the next fall. From a seeding made in the competition plots out in the field in 1939, this grass made a fine growth and produced much seed, but it is not yet known whether or not it will spread from the plots, or maintain itself.

Smilo.-The species, Oryzopsis miliacea, known as smilo or rice grass, is rated as about the most promising of the perennial grasses thus far tested. It makes a good winter growth and stays green late in the season. During the summer many of the grass blades dry and fall, which enables the plant to withstand extreme drought periods. This plant produces a good seed crop in most years. Abnormally dry weather during spring may prevent seed development.

Saltbushes.-Two large saltbushes (also called shadscales) now being tested are showing promise. One is a common forage shrub (Atriplex canescens) of arid sites in the southwestern and intermountain regions of the United States; the other (A. nummularia) is reported to be a 
good forage plant in Australia. An important object of the reseeding experiments is to determine whether some of these better browse species can be established in the granite area, to supplement in some degree the inferior native shrubs on this area and thus furnish more green feed during the summer dry-feed period.

In addition to testing of native and introduced plant species, plans for this project include assistance in field testing of improved forms of plants developed through plant-breeding work by the Bureau of Plant Industry and the California Agricultural Experiment Station.

\section{RAINFAIL RUNOFF AND EROSION}

Sierra Nevada foothill lands are chiefly valuable for grazing. This is their primary use. These same lands have important watershed values also, since with the adjoining higher mountains they comprise the drainage areas which supply municipal and irrigation water to extensive irrigated sections below. The effect of grazing on watershed values is a subject on which there has been little definite information for this particular type of land. In the summer of 1934, a special set of plots was established to furnish information on some of the numerous water problems, more particularly those concerned with surface runoff. No particular concern was felt about erosion, for the locality represented by the Range is not a critical range erosion area under reasonably good management.

The field setup for this experiment consists essentially of a group of 9 rectangular plots $1 / 40$ acre in size and equipped with automatic measuring and recording devices. The runoff from each plot is measured by catching the water in a concrete trough at the base of the plot, then running it through a settling tank and a specially designed tipping bucket which fills and empties as long as the runoff continues; with each tipping an electrical contact is made and automatically recorded. An intensity rain gage is also connected with the recorder. A continuous record is thus obtained for the total rainfall, the period during which it fell, and the total amount of resulting runoff.

The plots were left ungrazed for the seasons of 1934-35, 1935-36, 1936-37, and until March of the 1937-38 season, in order to determine their natural differences. During this period there was no appreciable erosion, and surface runoff was less than 1 per cent of precipitation, which indicates an infiltration capacity of this soil under ungrazed forage cover equal to or in excess of the highest rainfall intensities that occurred during that period. Precipitation on these particular plots for the first three seasons was 29.4, 22.7, and 23.3 inches, respectively. By March of the fourth season, precipitation amounted to 28.5 inches. 
After March 1938, and during 1939, three of the plots were grazed closely, three lightly to moderately, and three were left ungrazed. Precipitation for the rainy season of 1938-39 was 12.1 inches; for 1939-40, 21.7 inches. Under conditions that prevailed following these treatments, there was no significant increase in surface runoff from any of the plots as a result of grazing, on these particular gentle slopes. Surface runoff as here reported should not be confused with total water yield, which would include percolation, which was not measured in this study. The results indicate rather that most of the runoff from this granite-soil site of rolling foothill country with gentle slopes comes from seepage along the drainage lines rather than from overland flow down the slopes. This study, of course, has been running for too short a time to justify any definite conclusions.

\section{CHEMICAL COMPOSITION OF THE IMPORTANT RANGE PLANTS}

Seasonal trends in the chemical composition of forage plants common to the San Joaquin foothills have been presented by Gordon and Sampson (7) following a three-year study. The composition of the plants studied showed a rather close correlation within the different groups of plants, such as the grasses, the deciduous trees and shrubs, and the grasslike plants. The closest correlation, however, was found with the cyclic march to maturity as noted in distinct "growth stages." Species growing side by side may differ widely in composition; likewise, the same species in distinct growth stages may differ more widely in chemical values than the differences noted between various species of similar habit. Also plant samples collected on the same calendar date in two different years without regard to growth stages may fluctuate widely in chemical composition; but samples collected at the same growth stage are consistent in composition. Consequently, it was concluded that analytical data of a species whose sample is not representative of a specific growth stage has little or no bearing on the nutritional value of the plant. Moreover, to contribute to the question of the relative worth of a species as a range plant, chemical analyses at different growth stages, must be included.

The percentages of crude protein, and of calcium, phosphorus, and potassium in herbaceous species were found to decrease continuously in an orderly manner from the earliest appearance of leaf blades to plant maturity. With respect to crude protein, phosphorus, and potassium values, this downward trend, associated with development toward maturity, was found to be true also in deciduous shrubs and trees. In sharp contrast, the total silica-free ash and calcium in deciduous shrubs and trees increased as development progressed toward maturity. Crude 
fiber also increased with development in all plants except the deciduous shrubs and trees, the nondeciduous shrubs, and the half-shrubs. Crudefiber content remained constant in the deciduous shrubs and trees, whereas in the half-shrubs this constituent fluctuated much less.

All grass species investigated were high in caloric values, and in minerals, from the early leaf stage until they were in full bloom. The grasslike plants, such as the rushes, are relatively low in protein values and high in crude fiber by midsummer, but maintain value as late forage because they retain high succulence after grasses have dried up. The broad-leaved herbs fall into two forage categories: species having a short vegetative period but which maintain a high level of protein and ash contents well into the late flowering stage; and those having a long vegetative period and characterized by a low level of ash and protein when the flowering period is reached. Compared with other plants, the crude protein content of the leafage of deciduous shrubs and trees is high in the early leaf stage; and even when the foliage is mature this constituent is maintained at higher levels than in most species studied. Despite the fact that the nondeciduous shrubs are at no time especially high in protein or ash constituents, they, as well as the more nutritious deciduous woody plants, are important as browse. Both these plant groups remain succulent, and some maintain a fairly high level of protein and essential inorganic constituents late in the season when the herbaceous cover is at its lowest nutritional ebb; for this reason trees and shrubs supply important livestock feed.

Since grasses constitute an important part of the forage provided on the lands typified by the Range, the following criteria are suggested for their evaluation from the standpoint of chemical composition: (1) the interval between the beginning of growth and the flowering period must be long; (2) the crude protein content must remain at a relatively high level after the blossoming period, and well into the time that the seeds attain the dough stage; even after seed dissemination it is desirable that a portion of the basal leaves and stems remain succulent until late in the summer-a characteristic of many perennial grasses; (3) in the species whose herbage matures early a large proportion of the seeds must be retained after the leaf blades have become dry.

General criteria for judging the forage value of a range plant were found to group around high nutritive value through the life cycle together with a long period of vegetative growth. Most of the perennial grasses investigated have both these desirable characteristics. However, the importance of other range plants lower in nutritive values, yet having relatively long life cycles, was not discounted on an annual-type range. 
Although the forage is richest in most constituents in the early leaf stage, grazing intensively, or to the point of full utilization of the forage early in the season is regarded as undesirable. Many workers have shown that continuous close cropping reduces the season's total forage crop.

A supplementary study indicated that a short growing season, such as not uncommonly occurs in the foothill and valley regions of the state, may result in forage production particularly low in phosphorus, and in some species, in calcium. 


\section{CONTRIBUTORS AND GENERAL ACKNOWLEDGMENTS}

Contributors of the several subject-matter sections in this bulletin are grouped, by major agencies, as follows :

\section{Agricultural Experiment Station, University of California}

Adams, R. L., Professor of Farm Management, Agricultural Economist in the Experiment Station, and Agricultural Economist on the Giannini Foundation.

Carpenter, G. A., Research Assistant on the Giannini Foundation; resigned January 16,1940 .

Crawford, L. A., Assistant Professor of Agricultural Economics, Assistant Agricultural Economist in the Experiment Station, and Assistant Agricultural Economist on the Giannini Foundation; resigned January 1, 1941.

Guilbert, H. R., Associate Professor of Animal Husbandry and Associate Animal Husbandman in the Experiment Station.

Hart, G. H., Professor of Animal Husbandry and Animal Husbandman in the Experiment Station.

Sampson, A. W., Professor of Forestry and Plant Ecologist in the Experiment Station.

Storkr, T. I., Professor of Zoölogy and Zoölogist in the Experiment Station.

StorIE, R. E., Lecturer in Soil Technology and Associate Soil Technologist in the Experiment Station.

Voorhies, E. C., Professor of Agricultural Economies, Agricultural Economist in the Experiment Station, and Agricultural Economist on the Giannini Foundation.

WAgnon, K. A., Animal Husbandry Specialist at the San Joaquin Experimental Range.

\section{California Forest and Range Experiment Station, Forest Service, United States Department of Agriculture}

BiswelL, H. H., Associate Forest Ecologist; transferred September 1, 1940.

Nelson, J. W., Superintendent, San Joaquin Experimental Range.

Rowe, P. B., Associate Silviculturist.

TALBOT, M. W., Chief, Division of Range Research.

\section{Region 5, Forest Service, United States Department of Agriculture}

Cronemiller, F. P., Assistant Regional Forester, in charge of Division of Wildlife and Range Management.

Glading, BEN, Junior Biologist; resigned July 31, 1940.

\section{Fish and Wildlife Service, United States Department of the Interior}

FIтCH, H. S., Junior Biologist, Division of Wildlife Research; furloughed for military service May 22, 1941.

HoRN, E. E., Biologist, Division of Wildlife Research.

Credit is especially due F. G. Renner, formerly Forest Ecologist of the California Forest and Range Experiment Station, who was in field charge of planning, establishing, and supervising the forage experiments for the first two years, 1934 and 1935. Similarly, credit is due 
J. W. Nelson, present Superintendent of the Experimental Range, for administrative supervision of the whole coöperative program since 1935.

A. L. Hormay and J. R. Bentley, Associate Forest Ecologists, assisted in analyzing the results; and various students and other temporary field assistants, to whom individual credit cannot be given, helped from time to time in gathering the data.

CCC labor and various emergency funds have been of material assistance in the improvement and development of the area, including construction of fences, buildings, livestock watering places, corrals, and other facilities required for the different experiments.

Acknowledgment is due the Work Projects Administration for the original drawings of figures 5, 6, 7 and 8, made by Pat Haskey, under WPA Official Project No. 65-2-08-369; and for assistance rendered on various phases of the work on interrelations of rodents and other wildlife of the range, under WPA Official Project No. 165-2-08-225.

Throughout the period the workers have had the advantage of a stockman's advisory committee composed of producers of wide experience. They have thus been able to utilize the rich experience of this very representative cross section of the industry, to develop and foster a better understanding of the problems. This committee consists at present of the following men whose assistance is gratefully acknowledged: Harvey A. Russell, chairman; Hubbard Russell, American National Livestock Association; F. P. Cronemiller, M. A. Benedict, Region 5, U. S. Forest Service; E. L. Garthwaite, California Agricultural Extension Service; Theodore Chamberlin, W. Hugh Baber, Phil Klipstein, H. Clay Daulton, Eugene Mallory, Brooke Mordecai, Joe Urrutia, California Cattlemen's Association; H. E. Black, State Division of Fish and Game; Charles P. Campbell, State Division of Forestry; Craig Cunningham, Madera County Chamber of Commerce; Ernest Mason, Will Ryan, Madera County Farm Bureau; Charles Marsh, E. E. Nelson, Madera County Fish and Game Protective Association; Neils Overgaard, Madera County Agricultural Commissioner; C. T. Carver, C. L. Guthrie, Kern and Tulare counties; Irvine Armstrong, Monterey and San Benito counties; Charles Ellinwood, John Grohl, Sacramento, San Joaquin and Stanislaus counties; Walter Buell, Santa Barbara and San Luis Obispo counties; Jesse Bigelow, Herrick Brown, Neil McDougald, Jackass Cattlemen's Association; Archibald Shaw, Jr., Will Footman, Ahwahnee Farm Center. In addition, the coöperating staff members are ex-officio members of this committee.

The Bureau of Plant Industry and the Soil Conservation Service of the United States Department of Agriculture and various state and foreign agencies coöperate in the range reseeding project. 


\section{LITERATURE CITED}

1. BISWELL, H. H.

1939. A change in our California forage plants. California Cattleman. September. p. 4-5.

2. FiтcH, H. S.

1940. Some observations on horned owl nests. Condor 42:73-75.

3. Fluharty, L. W.

1939. Beef cattle enterprise efficiency studies. A four-year summary, 1935-1938 inclusive. California Agr. Ext. Leaflet. 48 p. (Mimeo.)

4. GLading, Ben.

1938. Studies on the nesting cycle of the California valley quail in 1937. California Fish and Game $24: 318-40$.

5. Glading, Ben.

1940. Valley quail census methods and populations at the San Joaquin Experimental Range. California Fish and Game 27:33-38.

6. Glading, Ben, H. H. Biswell, and C. F. Smith.

1940. Studies on the food of the California quail in 1937. Jour. Wildlife Mangt. $4: 128-44$.

7. Gordon, A., and A. W. SAMPson.

1939. Composition of common California foothill plants as a factor in range management. California Agr. Exp. Sta. Bul. 627:1-95.

8. Guilbert, H. R., and A. McDonald.

1934. Weight records on purebred beef cattle during growth, gestation, and lactation, together with data on reproduction. Amer. Soc. Anim. Prod. 1933 Proc. 26:244-53.

9. Guilbert, H. R., S. W. Mead, and H. C. JACKson.

1931. The effect of leaching on the nutritive value of forage plants. Hilgardia 6:13-26.

10. GUILBert, H. R., and L. H. ROCHFord.

1940. Beef production in California. California Agr. Ext. Cir. 115:1-125.

11. HART, G. H., and H. R. GuIlbeRT.

1928. Factors influencing percentage calf crop in range herds. California Agr. Exp. Sta. Bul. 458:1-43.

12. HART, G. H., and H. R. GuILBERT.

1933. Vitamin-A deficiency as related to reproduction in range cattle. California Agr. Exp. Sta. Bul. 560:1-30.

13. HART, G. H., H. R. GuIlbert, and H. Goss.

1932. Seasonal changes in the chemical composition of range forage and their relation to nutrition of animals. California Agr. Exp. Sta. Bul. 543:1-62.

14. Talbot, M. W., H. H. Biswell, and A. L. Hormay.

1939. Fluctuations in the annual vegetation of California. Ecology 20:394-402. 
